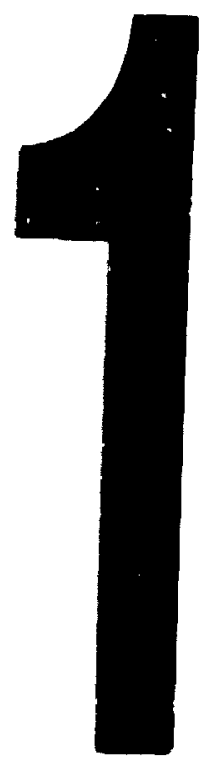

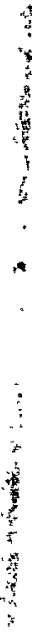

PM-1 3\%" $\times$ 4" PHOTOGRAPHIC MICROCOPY TARGET NBS 1010a ANSI/ISO "2 EQUIVALENT

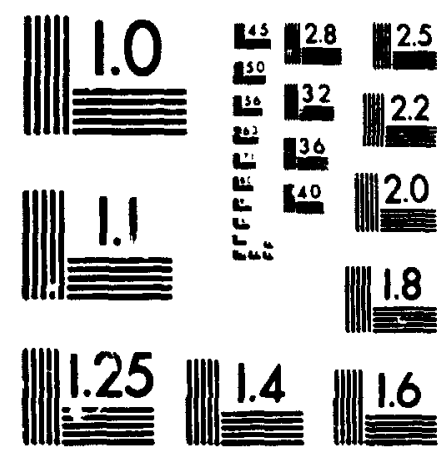




\section{National Library}

of Canada

Canadian Theses Service

Ontava, Canada

KIA ON 4
Bibliotheque nationale

du Canada

\section{Service des thèses canadiennes}

\section{NOTICE}

The quality of this microform is heavily dependent upon the quality of the original thesis submitted for microfilming. Every effort has been made to ensure the highest quality of reproduction possible.

If pages are missing, contact the university which granted the degree.

Some pages may have indistinct print especially it the original pages were typed with a poor typewriter ribbon or if the university sent us an inferior photocopy.

Reproduction in full or in part of this microform is governed by the Canadian Copyright ACt, R.S.C. 1970, C. C-30, and subsequent amendments.

\section{AVIS}

La qualité de ceite microforme dépend grandement de la qualité de la thèse soumise au microfilmage. Nous avons tout fait pour assurer une qualité supérieure de reproduction.

S'il manque des pages, veuillez communiquer avec l'université qui a conféré le grade.

Lâ qualité d'impression de centaines pages peut laisser à désirer, surtout si les pages originales ont été dactylogra. phiées à l'aide d'un nuban usé ou si l'université nous a lait parvenir une photocopie de qualité inférieure.

La reproduction, méme partielle, de cette microlorme est soumise à la Loi canadienne sur le droit d'auteur, SRC 1970, c. C-30, et ses amendements subséquents. 
THE STATUS OF DISABLED PERSONS IN CANADA; A HISTORICAL

ANALYSIS OF THE EVOLUTION OF SOCIAL POLICY TO

DEVELOF EFFECTIVE CHANGE STRATEGIES DIRECTED

TOWARD ACHIEVING EQUALITY

\section{by}

PAUL D. WRIGHT, B.S.W.

A thesis submitted to

the Faculty of Graduate Studies and Research

in partial fulfillment of

the requirements for the degree of

Master of Social Work

School of Social Work

Carleton University

Ottawa, Ontario

September 1, 1990

Q copyright

1990, Paul Wright 
Canadian Theses Service Service des theses canadiennes

Ollawa. Canada

KIA ON4

The author has granted an irrevocable nonexclusive licence allowing the National Library of Canada to reproduce, loan, distribute or sell copies of his/her thesis by any means and in any form or format, making this thesis available to interested persons.

The author retains ownership of the copyright in his/her thesis. Neither the thesis nor substantial extracts from it may be printed or otherwise reproduced without his/her permission.
L'auteur a accordé une licence irrévocable et non exclusive permettant à la Bibliothéque nationale du Canada de reproduire, prêter. distribuer ou vendre des copies de sa thèse de quelque manière et sous quelque forme que ce soit pour mettre des exemplaires de cette thèse à la disposition des personnes intéressées.

L'auteur conserve la proprièté du droit d'auteur qui protège sa thèse. Ni la thèse ni des extraits substantiels de celle-ci ne doivent être imprimés ou autrement reproduits sans son autorisation. 
The undersigned recommend to the Faculty of Graduate Studies and Research acceptance of the thesis

"THE STATUS OF DISABLED PERSONS IN CANADA: A HISTORICAL ANALYSIS OF THE EVOLUTION OF SOCIAL POLICY TO DEVELOP EFFECTIVE CHANGE STRATEGIES DIRECTED TOWARD ACHIEVING EQUALITY“"

submitted by Paul D. Wright, B.S.W.

in partial fulfillment of the requirements for the degree of Master of Social Work
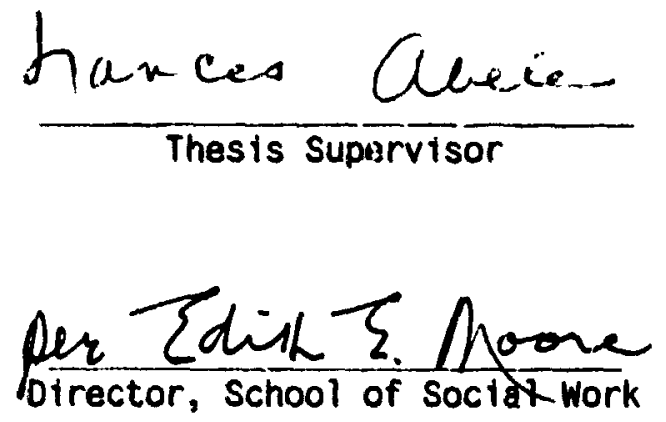

Carleton University

May 24, 1991 


\begin{abstract}
ABSSIRACI'
According to the argument presented in this thesis, public policy towand persons with disabilities, as is represented through prevailing Canadian social policy, actually diminishes the persons' opportunities for economic, political and social advancement, contrary to stated intention. This occurrence is the conseguence of prevailing conservative ideology, fuelled by capitalist system priorities, and stalus-(juu oriented societal arrangements which are dedicated to maintaining a system of unequal social relations. The subordinate status of disabled persons in the unequal Canadian social structure has historically been pronoted and maintained through tlac influence of conservative ideology on relevant social policies. Shifts in policy and ideology can be explained by fluctuations in the balance of power between various classes brought about by certain social and economic conditions, donestic and foreign events, and level of consciousness achieved by subordinated groups.
\end{abstract}

The process of change inplied by various social policies is analyzed in this thesis to yield methods for restructuring the Canadian social order. Similarly, strategies and future directives for elevating the oppression faced by all minuity groups are derived from this same historical analysis. 
THE CHOICE IS ClEAR; A NATION MAY FOLLOW CONSERVATIVELY ORIENTEDSOCIAL POLICY IF THE DESIRED OBJECTIVE IS TO REMAIN UNCIIANGED, OR THEY MAY SUBSTITUTE PROGRESSIVE POLICY IF THE GOAL IS EFFECTIVE PROBLEM RESOLUTION. 


\section{Table of Contents}

iii Abstract
iv Preamble
v Table of Contents

Chapter One: The Interplay Between Ideological and Material in the formation of Social Policy for the Disabled.............. 1

Chapter Two: Disabled Persons in Canada - The Social Model Perspective and Resulting Implications for Change............... 20

Chapter Three: The Historical Development of Canadian Social Policy for the Disabled in Past Intervention Efforts............... 44

1. War Veteran's Allowance Act............................................ 53

2. Blind Person's Allowance Act............................................. 57

3. Disabled Person's Allowance Act........................................ 63

4. Vocational Rehabilitation for Disabled Persons................ 74

Chapter Four: Community Services To Disabled Program; a Case Example of Regressive Programming Resulting from Misguided Policy.

Chapter Five: The Conditions of Social Change and the Role of the Disabled Consumer movement in Achieving Civil Rights

Chapter Six: The Quest of Social Change and Societal Transition as a Means to Resolve a System of Minority Subordination, The alteration of ideology to enhance material conditions for minority groups

Appendix I: Participation Rate by Disability Status, Sex, and Age Group.

Appendix Il: Disability Status by Age Group and Current Education Level. 
CIIAlYIiR ONI: The Interplay Between Ideological and Material in the fiormulation of Sixial Policy for the Disabled

Disabled persons have always presented liberal democratic countries with a secmingly unresolvable dilemma. What should be done with a large segment of the pupulation who have been granted exemption from normal citizen requirements and expectations of eco:..smic self-sufficiency by virtue of their incapacity to use traditional sacietal opportunities? In contemporary Canadian society the dictates of democracy delermine that such persons should have equal opportunity to gain access to societal resources necessary to achieve a comfortable life style as do non-disabled peers, yet prevailing ideology defines disabled persons as extraneous to the productive requirements of a capitalist economy. They are considered a drain upon the economy because subscription to human rights necessitates financial maintenance at the entire society's expense. This research project will challenge the ideological myth responsible for producing the artificial dilemma and subsequently propose corrective social change strategies. The conclusions are derived from an analysis of the historical development of sucial policy relating to disabled persons in Canada.

This paper describes the theoretical perspective that is employed throughout for conceptualizing and analyzing the researched material. It is argued here that a Marxist derived philosophy most adequately describes the Canadian, liberal democratic, capitalist social structure in terms of component and underlying mechanisms. In conjunction with Durke imand Weber's theories of state and the role of ideology, in guiding societal consciousness the Marxist perspective provides 
a useful tool for analysis thus yielding a more valid assessment of the role of the state. Next this paper presents will relevant social status indicators for disabled persons in Canada as are gauged over time and against the non disabled population. This section will include discussion of competing paradigms used in the interpretation of these indicators. The argument here is two-fold. First it is demonstrated that in spite of nast social policy resolution efforts the problem of social inequality for disabled persons still exists in all areas of life and has even been perpetuated in relative terms. The corollary to this argument is that previous social policy has been made ineffectual in part by the maligned charity and medical paradigms employed to interpret social indicators and develop remedial policy. A more socialist oriented perspective is proposed as a replacement to the prevailing analytical paradigm. This section is followed by a historical analysis of policies and prevailung social conditions relevant to disabled persons. It is submitted here that by analyzing prior efforts aimed at resolving the problem of inequality encountered by the disibled, more proactive and prospective strategies can be devised. The next section contains a sample illustration of an operationalized program, authorized through social policy for disabled persons. This example provides evidence of how conservative ideology works to bias legislative intention which subsequently sabotage the program at the implementation phase. The final segment overviews and assesses the most recent movement in policy for disabled persons and discusses the social change strategies responsible for it's existence. It is argued in this chapter that the change effort in question was relatively successful when compared to predecessor policies. Credit for 
the success of this policy directive is given io the more accurately targeted socially proglessive oljective and the pressure from preliminary events traced directly to the tise in activism of the disabled consumer movement. Refinement of the lesson keirned by studiying this era is submitted to serve as a useful future blue print for social change. This paper then secks to synthesize the information and conclusions surveyed tin discuss strategies for future action and the development and implementation of alternative replacement pol':-ies. From this analysis it is concluded that cooperation between oppressed minority groups and the enlistment of a more proactive approach for altering the present societal arrangements is essential to ellectively climinate the current situation of minority subordination.

While this thesis bribadly addresses the role of the Canadian political economy III perpetuating a system of unequal societal relations through social policies, it also discusses the uscfultiess of social policy for recifying the situation of inequality. The theoretical model employed for conceptualizing data relies heavily upon a Marxist based intalysis guided hy a conflictual understanding of social change. The subject maller is thus analyzed by examining the political structure, social relations and ccomomic systcm arising from the prevailing capitalist and conservative ideologies.

The Marxist perspective is more useful for accurately understanding and Icsolving social problems than the commonly applied structural-functionalist derived viewprint. Stuctutal-functionalism as a conservative perspective has the effect of 
maintaining the existing status-quo arrangements and inhibiting the development of socially progressive societal change. According to this perspective, society is conceptualized as a large self-adjusting mass subject to automatic consensual reformation as is warranted to maintain a healthy state of functioning and societal well-being.' However, this theory of society does not address the systematic subordination of minority groups to dominant group interests, and denies the conscious role of coercive elements in the process of forced cooperation. ${ }^{2}$ It is therefore unrealistic to understand society as a collection of individuals functioning with a common purpose. Alternatively society may be considered numerous and varying segments of groups always in contlict, differentiated but held in place by statc sponsored elements of social control. It is interesting to note that discriminatory conditions confronting subordinated minority groups have improved significantly during periods when minority power bases were enhanced by societal turmoil, decreased or re!axed state control, and during periods of comprehensive and unilied confrontation. $^{3}$

The central theme of this paper is that progressive social change occlirs only under conditions of conflict. Accordingly, society is characterized as segmented into competing components each possessing varying degrees of power and thus different capacities to realize goals. This paper will concentrate heavily upon the social components known as state agencies which continually interact with prevailing ideology and have the underlying purpose of inhibiting social change by averting 
conflict and fostering stability partially through the implementation of social policy. ${ }^{4}$ In the final chapter the development of counter balancing revolutionary social components is discussed. According to the explanation contained in this paper the role of the state is to foster stability which consequently maintains the prevailing system of social inequality which disadvantages persons with disabilities and all powerless minorities in general. The principle mechanism by which the process of minority subordination is perpetuated and administered is social policy. Social policy represents the empirical reality to be analyzed here. Sucial policy traditionally developed according to the misleading consensual model for understanding society has not resulted in significant problem resolution or the large degree of resource, power, and status redistribution required to eliminate social problems.

Employment of the conflict paradigm in the analysis and reconstruction of social policies is warranted as a means to develop the alternative policies and plausible implementation strategies for effectively resolving social problems. The appiication of a conflict perspective for understanding and rectifying problems of socictal organization is necessary to uncover the root cause rather then follow a consensual model which essentially focuses interventive strategies upon symptom resolution. For example, the consensual spproach may aim to correct individual dysfunction wisile a conflict model may focus upon pover differential variables and the intluence of ideology. The consensus model thus disproportionately blames social problems on the individual while ignoring the more relevant societal processes. The 
conflict approach utilized in this paper is more conducive to identifying the real cause of the problem of inequality confronting the disabled.

While Karl Marx laid the basic foundation for analyzing capilalist society according to a conflict paradigm, Max Weber's work provides a useful supplement because he discusses the role of the state and bureaucracy in much greater detail. In simple terms, Marx saw society as being shaped primarily by a system of unequal class relations. ${ }^{6}$ Derived from the class relations base were the socielal institutions dedicated to continued maintenance of the prevailing structure through legitimation and coercive action. ${ }^{7}$ Weber challenged this basic materialist formulation by emphasizing the role of ideology and discrediting other explanations as being conservatively biased and subjective. This paper seeks to synthesize the two perspectives by viewing the occurrence of inequality in society as a complex interaction between material conditions and jeological promotions.

According to a historical perspective, the rise of capitalism as a dominant economic force coincided with and shaped existing ideology thereby fragmenting relations between and among people, and mediating all social interaction through the requirements of the labour market. ${ }^{8}$ The development of a multi-levelled class system consequently produced conflictual relations between those advantaged by their position inclıding material holdings, and those deterred from ascription. A major function of ideology according to Weber was to inhibit the emergence of conflict and 
thereby diminish inter-class tensions and opportunities for social change. ${ }^{9}$ Ideology in relation to a capitalist social structure may be viewed as the cause, consequence and catalyst for the present unequal social order.

For Weber an understanding of capitalism was also an analysis of class domination in every aspect of the system. He sought to determine how the actions of state agencies came to benefit one specific class to a greater extent than others. To be deemed legitimate state action must appear to be grounded in public interest, but more frequently is motivated by and in the interests of powerful minority groups. This one-sided result is made possible by the structure of the Canadian political system, characterized as liberal-democratic, in which decision-makers are to be elected from the general public. However selective pool characterized by those who already enjoy advantaged positions in the social structure, from which candidates are derived nullifies opportunities for equal class representation. Decisions become heavily influenced by a need to maintain the status quo thus deterring radical social order change. Weber discusses the myth of representative democracy as a means by which politicians subtly force citizens to conform to a certain vision of society under state-promoted ideological beliefs. Certain features, like reliance on a political party system may he partially responsible for this situation however it is more likely that cconomic influence in political structures is upheld unintentionally by criteria limiting membership of key state positions and structures to those already possessing wealth, prestige and power. Finally according to Weber, capitalism is the rational pursuit of 
profit for the purpose of capital accumulation through expansion and further exploitation and surplus value from workers. Many problems are rooted in the fact that the profit motivated economic system has become central and dominant to all human social relations as opposed to a more equitable system of resource distribution. ${ }^{10}$

Social class is an artificial distinction between groups of people, dependent upon individual possession of wealth, prestige, power, status, and ownership or control of the means of production. For the purpose of this paper, one variable defining class membership can also be the ability to influence state structures. An unequal class structure is a necessary component for continued survival of a capitalist profit motivated economical system. ${ }^{11}$ The state can be considered an expression of and vehicle for promoting favourable conditions for capital accumulation. The state is composed of all agencies in the public sector which are controlled by government. Most state organizations are characterized by control of power through hierarchical management structures known as bureaucratic systems. A bureaucracy is a certain structure of organization found in all state agencies. Bureaucratic structures are characterized as; having an appearance of being scientific and rational, governed by rules and regulations, dehumanizing and alienating, structured according hierarchical authority, having a complex division of labour, maintained through cherished custom and/or ideolog:al belief. ${ }^{12}$ These characteristics of bureaucracy are conducive to perpetuating prevailing conservative ideslogy which provides both the motive and 
rationale for inhibiting social change. A key element providing motive and rational for the creation of these organizational structures is the attainment and maintenance of power.

Power is an important variable when seeking to understand liberal democratic systems. Ralf Darendorf defines power as the ability to impose one's will over the actions of others. ${ }^{13}$ Attainment of power depends upon that which is socially legitimated. Regardless of the source from which power is derived two important aspects need be noted here. First it is artificially created and maintained by religious belief (ideology) and custom including that which has originated from unequal class relations and is presently maintained through traditionally valued dimensions like status and position. Second it carries with it the ability to, and the necessity for, exerting control over others to preserve the artificial mythical belief base upon which the authority is granted in the first place. ${ }^{14}$

State agencies depend upon socially legitimated power to enact their function. A principle role of the state is to stabilize class conflict without fundamentally altering capitalist social relations. Social policy produced through the capitalist state exemplifies liberal reform which does not alter fundamental power relations. ${ }^{15}$ Capitaiist control of state structures is not so much an overt predetermined exercise, but rather is dictated by the underlying common philosophy. The values and ideology of the state and the capitalist class are one and the same. ${ }^{16}$ Both require and 
promote social control. While the social control objective is inherently alienating to the public the state protects an image of neutrality through legitimization promotions. Such measures simultaneously avert conflict which could potentially destabilize society and result in radical social change. Measures of social control may take many forms ranging from propaganda and a certain stream of ideology taught in the public school system to violent force employed by police agencies. ${ }^{17}$ Here it becomis apparent that state agencies must exhibit multiple and seemingly contradictory purposes to fulfil the task of societal stabilization. An example of dual function in state agencies is demonstrated by Jeffry Galper in his analysis of the social welfare system. According to him the social welfare system operates as an agent of social control forcing clients to conform to rules and regulations as a condition for receiving financial benefits, premised on humanistic motives. In the contradictory pursuits, the social control function always over shadows other goals. The social control function may be defined here as having an objective of inhibiting conflict by controlling the actions and behaviour of people. All social organizations are sanctioned by the broader economic and political systems only if they validate and protect the existence of the prevailing social order. ${ }^{18}$ As was mentioned earlier, ideology is both incentive and a tool for perpetuating the roles and goals of state institutions.

Dominant ideologies arising from the protestant work ethic, individualism and liberalism, construct a perception and individual consciousness which coincides with the existence of a capitalist based system but undermines the importance of social 
responsibility, fragments social relations, and limits individual growth potential beyond the requirements of the labour market. ${ }^{19}$ These same ideological formulations promote the existence of, unequal social class, prestige, and status, as being naturally occurring phenomenon when actually such classifications are artificially produced social dimensions vital only to power and system maintenance.

The combined influence of institutionally sponsored ideological beliefs, materialist conditions, and socialization processes influence personality development conducive to the willing acceptance of social control. The chain of events described here are schematically depicted in the following flow chart.

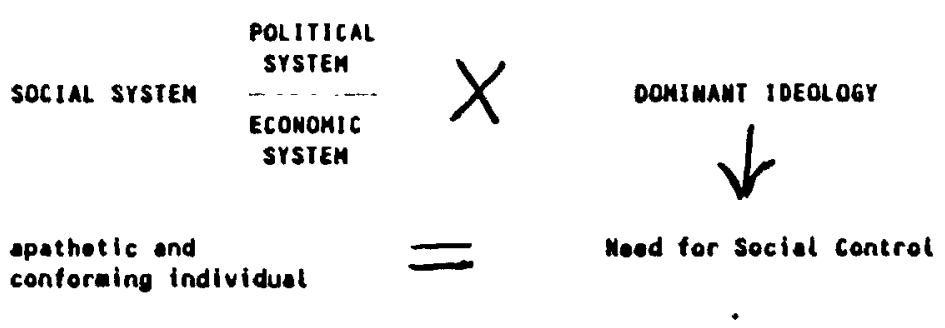

There are many elements that may cumulatively account for the internalization of inferior status among minorities. Disabled persons for example are subjected to perceptions of inferiority through everyday life circumstances of inadequate housing, poor access to services, insufficient education, substandard medical care, inaccessible transportation, financially unavailable legal representation, deterrence from exercising voting and political rights, bureaucratic alienation, forced dependence, segregation, poverty, and general societal indifference. The final impact of these conditions upon 
individual personality is a disempowering, internalized sense of social disability, characterized by feelings of inferiority and helplessness. The ultimate product of this process is individual internalized social control. ${ }^{20}$ Ironicaily the same system which creates these processes also depicts disabled persons as being redundant to the requirements of capitalist production for profit and therefore representing a social problem and a burden for all of society. Sociologists have theorized that social problems are identified according to a consensus based social relations perspective and responded to as a matter of convenience through interactive partial strategies by state agencies through the authority base of social policy when the sociely's stability is threatened and increased social control becomes necessary. ${ }^{21}$

Disabled persons were treated with complete indifference historically until certain events made some form of official response necessary to stabilize societal relations. I will argue that the state response was ineffective for achieving the stated goals of policies because elements of the policy development process were guided by state directives and capitalist ideology. The development of social policies, according to this perspective, can be thought of as arenas for struggle between classes whereby concessions outside of the normal requirements of a pure capitalist system can be won or lost. The form taken by the social policy exemplifies the product of the struggle. ${ }^{22}$ The following hypothesis has been generated from the aforementioned theoretical perspective. 
The subordinate position of disabled persons in the Canadian social structure has historically been promoted and maintained through certain ideologies entrenched in relevant social polices and influenced by these occupying powerful positions. Shifts in policy and ideology can be explained by changes in the balance of power among classes (and factions of class, such as disabled persons). This occurrence can be analyzed to develop alternative policies and strategies for implementation.

To summarize, inequality facing disabled persons is produced and perpetuated by contemporary jdeology and state functions as are mediated by regressive social policies and influenced by those occupying powerful positions. This paper contains an analysis of the evolution of key social policies as are directed by prevailing jileology, by ex:mining basic premises, elements of composition, development process patterns, power relationships, environmental circumstances, and net effect upon the target and other related groups. This analysis confirms the hypothesis that inequality contronting the disabled arises from negative ideologies ingrained in social policies and can only be altered through shifts in the balance of power between different classes and sub-groups.

limproving the social status of disabled persons to a level equal to non-disabled peers would entail reconstruction of the present social order. To achieve this mammoth task of societal reconstruction will entail no less than the substitution of current ways of thinking including introduction of competing social institutions with 
more socially progressive strategies. Relations between and among people will need be altered from the present format of individual self serving responsibility (o) a more socially responsive and equitable perspective. It is argued here that a prime mechanism for promoting the goal of dominant ideological change is social policy and related legislative efforts.

This exercise thus provides incentive and impetus for developing alternative policies to be implemented with new or refined strategies. Legislation for disabled persons was thus chosen as the subject for analysis since it represents the legai codification of public policy or evidence of societal commitment to the achievement of certain goals. Although legislation for disabled persons is used as the topic, the focal point will be the change process by which such policies have evolved or been altered. When viewed as a struggle between social reformers and those seeking to sanctify capitalist economic values, legislation for disabled persons can be understood to entail the events preceding development and the actors influencing the final result; all of which are engaged in a complex interactive dynamic with the prevailing ideology. According to the analyticai framework employed here, all change results from conflict between opposing forces and the product afterward contains elements advanced by either side. Within such interactions attention for the purpose of analysis should focus upon the role played by; natural forces, such as the biological and physical characteristics of the disabled that cue categorization; the material conditions and power differentials between those proposing the policy and those who 
are subjected to it; human designed principles, such as the prevailing dominant ideology and customs; and major events such as the occurrence of global war or economic recession.

Chapter two, simply titled "Disabled Persons in Canada; The Social Model Perspective and Resulting Implications for Change", conveys an appreciation of the disabled' inequality complimentary to a social model paradigm. It reviews how the status of disabled persons have evolved in the past fifty years in relation to the non-disabled population according to selected indicators as measures of equality. This chapter also displays a brief description of relevant external forces that may have influenced the development of policy for disabled persors during the various sclected instances.

Chapter three is titled "The Historical Development of Canadian Social Policy for the Disabled", and briefly describes possible incentives for the initial state responses to the disabled as a social problem. It further analyzes past examples of policy in a manner conducive to clear explication of vested interests and concealed motives. Examples of policy to be evaluated at this time include; The Veteran's Pension Act, as the first concrete piece of legislation for the disabled; The Blind Persin's Act, because it was folnaded heavily on the charity ethic; The Disabled Person's Act, which emphasized the provision of institutionalized charity but included a rehabilitation philosophy; and finally the Vocational Rehabilitation for Disab.ed 
Person's Act, which represented a complete departure toward rehabilitation and a slightly more progressive ideology related to disabled persons. The method of evaluation is borrowed from a schema developed by David Gil. Gil's approach is designed to facilitate the emergence of alternative policies while high lighting problematic portions of existing legislation in relation to class power relations. According to his perspective social policy effects all domains of human existence including the overall quality of life, circumstances of living for individuals and groups, and intra-societal relations between and among citizens. Social policy affects these realms through ideological intluence and the distribution of status and rights. The determinants of policy contents are said to be the dominant beliefs, values, customs, and jdeologies arising from conflicts between various interest groups, the degree of differentiation, stage in technological development and major societal events. ${ }^{23}$

Chapter four contains a case study demonstrating how distorted policy and mistaken ideology may result in a completely biased social program rendered chronically ineffective by the same misguided values and beliefs. The program to be considered in this chapter is the Community Services to the Disabled (CSD) program announced in the mid 1980's as a pilot project by the Department of Ileaith and Community Services in New Brunswick.

Chapter five is entitled "A Shift in Policy Ideology from Charity to Civil Rights; A Progressive Policy Alternative", and contains a detailed account of the conditions 
and circumstances resulting in the 1983 iluman Rights Act amendment including disability as a category for discrimination. This section is primarily concerned with the impact of chance events upon the final policy outcome. It is supplemented with a segment utilizing David Gil's framework to determine the difference between intended and actual consequences during the policy's actual implementation. The analysis and evaluation in this chapter brings to light the opposing forces in the change process and explains accordingly why the policy has failed to be $100 \%$ effective.

The final chapter contains conclusions and logically deduced directives for future action based upon an application of the theoretical perspective depicted in the introductory chapter. Strategies of increased political consumer participation, mobilization, and coalition building, both among various groups of disabled persons and across all powerless minorities, as a means to pressure for meaningful solutions by altering the power differential, are advocated for in this chapter. 


\section{END NOTES}

1. Proposed by Talcott Parsons and restated in A.W. Djao, Chapter 5, Inequality and Social Policy, Toronto, John Wiley + Sons, 1981).

2. Thomas J. Bernaru, The Consensus Conflict Debate, New York, Harper Ruw, 1983.

3. Anthony Oberschall, Social Conflict and Social Movements New Jersey, PrenticeHall, 1973.

4. Ibid.

5. A.W. Djao, Inequality and Social Policy, Toronto, John Wiley + Sons, 1983.

6. Karl Marx, and Frederich Engels, Economic and Philosophic Manuscripts, 1844.

7. Ramish Mishrä, Chapter 5, Society and Social Policy; Theoretical Perspectives on Welfare, London, Mac Millan Press, $19 / 7$.

8. Max Weber, The Protestant Ethic and the Spirit of Capilalism, New York, Scribner, 1958.

9. Ihid.

10. Robert K. Merton, Social Theory and Social Structure, Chicago, Free Press, 1957.

11. Leo Panitich, ed. The Canadian State; Political Economy and Political Power Toronto, University of Toronto Press, 1977.

12. P.M. Blau, The Dynamics of Bureacracy, Chicago, University of Chicago Press, 1955.

13. Ralf Dahrendorf, Out of Utopia: Toward a Reorientation of Sociological Analysis, American Journal of Sociology, 64, September, 1958.

14. Gad Horowitz, "Conservatism, Liberalism and Socialism in Canada; An Interpretation", Canidian Journal of Economics and Political Science, XXXII, May 1966.

15. Irving Abella, ed. On Strike: Six Key Labour Struggles in Canada 1919.1949, Toronto, James Lewis Samuel, 1974. 
16. Wallace Clement, Continental Corporate Power Ottawa, McLelland and Stewart, 1977.

17. Karl Marx, and Frederick Engels, The German Jdeology, 1870.

18. Jeffry II. Galper, The Politics of Social Services, New York, Prentice Hall, 1975.

19. Pal Marchak, Ldeological Perspectives in Canada Toronto, $M^{c} G$ rall-Hill Ryerson, 1981.

20. Elizabeth Taylor-Vance, "Social Disability", American Psychologist, Vol. XXVIII, 1973.

21. Anthonony M. Platt, The Child Savers: The Invention of Delinquency, Chicago, University of Chicago, 1969.

22. Roy Hanes, "The Cripples Image; Issues of Dependency, Morality, and Character", Unpublished paper.

23. David Gil, Unravelling Social Policy, Massachautsetts, Schenkman, 1981. 


\section{CHAPTER TWO: DISABLED PERSONS IN CANADA -- TIIE SOCIAI MODLI.} PERSPECTIVE AND RESULTING IMPLICATIONS FOR CHIANGL

The major barriers to attaining social equality for disabled persons, according to a recently submitted report by the Secretary of State, were; societal perceptions, systematic barriers, socially instilled apathy, and to a lesser extent, individual pliysical limitation. In fact disabled Canadians are the most repressed citizens of the industrially advanced countries. Canada has the highest institutionalization rate of the eighteen leading industrialized nations (19\% of disibled females and $12 \%$ of disabled males). ${ }^{24}$ The situation of inequality facing disabled persons does not lie: with individual fault as the traditional medical model concludes, but rather with extraneous factors beyond the individuals control or even consciousness. The situation of inequality confronting disabled persons can be shown to arise not from individual fault or biological flaw but rather from artiicially constructed conditions. The social model philosophy, examined in this chapter, may be more usctul to realistically uncover the cause behind the repression of disabled persons.

The concept of disability is commonly looked upon by the majority of Canadians with pity, horror, grief, or at best, indifference and apathy. It brings to mind many negative sentiments and unflattering images of pain, suffering, ugliness, and abnormality. Historically disability has been equated with punishment for immoral behaviour. Disability is to be avoided at all cost and if evasion is not possible, atonement must include an unquestioned ejesire to return, as closely as 
possible, to a non-disabled state of being. The common symbols of disability include wheel-chairs, canes and crutches, strewn with darkened, disfigured, twisted, not quite human forms. One extension of these representations conveys impressions of the disabled as having supernatural abilities motivated by either extreme evil or divinity. ${ }^{25}$ The institutionalization and maintenance of these largely negative associations can for the most part be attributed to media treatment of disability, social and medical service professionalism, and the demeaning consequences of the predominant philanthropic ideology. The resulting negative ideology has bred state responses riddled with dysfunctional solutions. Thus many social programs seek to either marginally assimilate, totally eradicate or subdue with charitable relief. Such policies serve to perpt.uate the negatively biased ideology rather then intibit it. ${ }^{26}$

The mass media conveys a needlessly negative impression of disability as an individual problem. This image is internalized as objective reality by both the disabled and non-disabled. The average Canadian citizen's includes socialization bombardment with images of disabled villains and persons otherwise filled with revenge and evil or inspired with saintly providence after coming to terms with their inadequacy. Most television depictions, when disabled people appear at all, locate disability as being central to the actor's personality and role but never secondary an: periferral. Magazine advertisements selling on the premise of sexual appeal and beauty, always utilize non-disabled models and in doing so convey by association an impression of disability as being undesirable. ${ }^{27}$ Canada's national heros are almost 
never disabled. When a disabled hero emerges he or she becomes the mentor of his or her sect of disabled persons and an example of triumph over individual disability. During the recent Rick Hansen world tour the public became fixated on the point that he was raising money for spinal cord research to enable disabled persons to walk rather than other the main goal of seeing disability in a positive light. Steve fonyo too quickly fell from grace after being charged with driving while intoxicated. Media coverage did not consider the normality of the incident to be of public interest. Terry Fox will be remembered by the public for his efforts to overcome individual disability while those who fight all there life to gain civil rights for the disabled are often ignored or pass unnoticed. Finally, labels like handicapped, invalid, retard, mongoloid or cripple, and unconsciously abusive phrases like; "fell on deaf ears", you must be blund", and "you're retarded", serve to further devalue persons with disabilities. Through these many ways a certain vision of disability is perpetuated and ingrained without question. This effect is compounded in the case and experience of double minorities like women who are also disabled. Once firmly implanted it functions to then condone discriminative actions, societal indifference and a system of inequality. The implications of this phenomenon upon disabled status and life conditions are staggering and touch upon every aspect of socistal existence. For exampic, a diminished sense of personal capacity among the disabled community is made reference to by the 1987 social participation rate for the disabled which found that $31.6 \%$ of the disabled were active compared to $69.2 \%$ of the non-disabled. ${ }^{28}$ It should be noted for future reference that the same repressive circumstances and 
resulting individual characteristics exist to some degree in every minority group. General commonaitities are found in minority groups in that they; are clearly defined as being different from the dominant group, are diminished in terms of social, political and economic power relative to the dominant group, and are subjected to arbitrary discriminating conditions. ${ }^{29}$

The previously described components of discrimination are both, impelled by a negative demeaning ideology, and the cause maintaining the existence of devaluing stereotypes. Furthermore negative ideology may represents one of the most significant underlying barriers to the achievement of disabled equality, mainly because it guides the public consciousness and in doing so limits the solutions proposed in remedial efforts. According to this thesis a more enlightened perspective is needed to reflect occurrences in the day io day reality of disabled persons. The medical model sechs to explain social problems as resulting from some pathological and deviant individual characteristic. Individual problems are subject to diagnosis and treatment at the microscopic level, without consideration of environmental factors. According to the social model biological or psychogenic factors are considered secondary to environmental influence. This perspective is especially concerned with the effect of artificially human produced constructs like culture. ${ }^{30}$ Thus a more valid perspective is exemplified by the social model approach capable of generating more effectively plausible remedies for resolving social problems like creating conditions of equality for disabled persons. By contrast, where the medical model driven 
approaches breed only status-quo oriented, change inhibiting and individually focused strategies, the social model emphasizes change in environmental conditions and the structure of societal organization as a means to resolve social problems. The applicability of the social model for resolving inequality facing disabled persons will become apparent by examining and contrasting the consequences implied when using either perspective. When the medical model is used to cor pprehend and categorize disabled persons the dilemma frequently faced by politicians, bureaucrats, administrators and professionals is how to account for individual differences among sub-groups yet propose an all inclusive policy directive aimed at reducing the problems encountered by disabled persons. ${ }^{31}$ To rationally understand this group of persons with the medical approach the chief bisection among the disabled is made according to biological and physiological characteristics. Mental and physical ability become the criteria for applying symptomatic labels. ${ }^{31}$ Further divisions may be based upon causal circumstances and attribute value judgements of fault; for example, congenital, accidental, drug dependent, or alcohol induced labels are often applied in this respect. Long term, short term, temporary or permanent, are other factors commonly used to breakdown the group into operationalizable units. For further simplification and analysis each major segment may be subdivided into categories based upon type of impairment yielding labels like mobility impaired, hearing impaired, and blind, while mental disabilities are separated into diagnostic categories like psychotic, psychopathic, dementia, anxiety depressive, learning disabled, and etc... ${ }^{32}$ Regardless of the actual degree of fragmentation or number of 
classifications invented and imposed, all have in common individual assessment of the problem and a dehumanizing affect on the person. Disabled persons are conceptualized along a deviant spectrum as opposed to a normal continuum. These categories also have an additional consequence of alienating disabled persons from other disabled persons on the basis of only minor functional differences and thus reducing any chance of collective action. The social model approach enlists the use of only one criteria to delimit categorization and thus greatly, simplities the parameters of group inclusion. This perspective does not deny the existence of individual differentness but rather emphasizes unified group membership by emphasizing the role of the environment in attributing meaning to the impairment. It focuses upon sameness of condition rather than differentness of functional impairment. The only relevant criterion defining the parameters of disability otherwise known as minority status is the application of social discrimination. Person's considered to have multiple minority characteristics can assume to be experiencing a corresponding degree of discrimination as a result of any form of physical differentness. Using this definition, most members of all minority groups can be considered disabled. Thus the unit of classification, the motive for unification and means to problem resolution, are intricately linked and indistinguishable.

Chapters three and four will discuss these narrow definitions of the problem and target group flowing from conservative ideologies which are responsible for misdirected corrective measures in policy and program directives. A social model 
focus upon discriminating circumstances in the environment facilitates the development of more effective reconstructive strategies, advocating for the unification of all minorities by targeting for change the existing arrangement of societial conditions and relations between people for change. Policy would not be assessed only in relation to the fragmented target groups but also according to the effects upon non-target groups, and similarity consider additional unintended consequences. The absolute amelioration of the real issues at the heart of the problem would be the primary directive. The Canadian Council on Social Development (CCSD) noted in 1977 that;

"Handicap (disability) is therefore a phenomenon in our society which is common but may be overlooked or, alternatively may be exaggerated as a social problem... different needs can be assessed and appropriate plans and provisions can be made by governments and their agents to meet these needs."

This symptom intervention approach has been the choice of policy makers for half a century and has met with little success because the individual focus excludes societal alteration solutions. The problem is not that certain incividuals do not fit into the system but conversely that the system is too rigid to accommodate individual difference. All persons have needs that are not met by the prevailing social structurc and the case of the disabled simply represent one extreme example of such disparity. From the perspective utilized here a number of concepts differing qualitatively from 
traditionally biased definitions should be explained before proceeding further. Predominantly, the concept of social disability is crucial in that it is the common denominator in the process of oppressing disabled persons and all minorities in general. The social model does not deny the objective existence of disability . differentness but rather considers it to be a cue signalling the application of socially restricting circumstances. The application of such conditions, accidentally or iatentionally, are always prompted by individual attributes. The type of discrimination, known here as social disability, usually takes the furm of unequal resource distribution, blockage from opportunities generally open to the public, and socially sponsored indifference. Other concepts derived from the social model and will be discussed here include;

DISABIED STATUS - refers to the level of well being for persons with disabilities across all aspects of society and in relation to the general population, as are gauged by various social indicators.

TIE DISABLED - refers to a state of consciousness whereby differently-abled persons come to realize socially sanctioned discriminating conditions and cease to locate the cause of their problems in individual fault.

IIANDICAP - is the factor expressing the degree of disadvantage experienced by a disabled individual because of environmental conditions. 
IMPAIRMENT - is the individual differentness signalling administration of discrimination. Impairments are made apparent by unaccommodating environments (handicaps) and ultimately categorization as a disabled person.

SOCIAL INEQUALITY - is a societal arrangement whereby persons are segmented at varying levels in hierarchical fashion according to attainment or possession of wealth, prestige, power, other resources, uscfulness to the labour market, and ability to intluence state structures.

STATE - is an institution incorporated as a vehicle for expressing, legitimating, developing, implementing or enforcing government policy. The chief function of the state includes societal stabilization and social control through the mediation of conflicting class interests.

SOCIAL POLICY - is a statement of government intention for allocating resources and statuses, and determining relations between and among people. It is an expression of state priorities.

PROSPECTIVE, PROACTIVE SOCIAL POLICY - is forward looking, anticipatory social engineering designed to completely resolve problems of social organization according to a long term egalitarian vision. It is the opposite of conservative social policy presently in practice. 
In line witt. the objective view of disabled equality offered by the social model persn witive it becomes apparent that the disabled face situations of inequality in the social, political and economic realms of society. While marginal gains have been made in some areas, relative differences to the non-disabled population nullify the absolute value benefit of any such advancement. In the recreational field, many structures are not accessible or opportunities to participate simply do not exist. ${ }^{34}$ Educational organizations insist upon a non-disabled core curriculum, segregation, inaccessible facilities, lack of qualified teachers and stereotypical attitudes. ${ }^{35}$ Health facilities are underfunded and seek medical biological cures instead of emphasizing the provision of equality enhancing resources and opportunities. ${ }^{36}$ Transportation systems are inadequate and segregating. ${ }^{37}$ In the political realm many disabled are denied voting rights and direct participation by virtue of diminished power and economic status. Many polling stations remain inaccessible while solutions are paternalistic and condescending. ${ }^{36}$ Few decision makers are disabled. In the economic sector, the disabled are among the most disadvantaged financially. Using employment indicators as the chief measure of economic capacity disabled persons have the least potential for prosperity. A recent BOOST report noted;

"Responsibility for finding jobs for disabled Canadians has largely been left to the voluntary agencies, and considering the predominance of business and professional people on the boards of directors of these agencies, is it not fair to ask why the unemployment rate among the disabled in Canada is still so high?"39 
At present $57 \%$ of disabled persons between the ages of $25-54$ are in the labour force compared to $79 \%$ non-disabled in the same age category. ${ }^{\text {to }}$ The government is not leading by example, as they had promised publically, since only $2 \%$ of disabled people are employed by the public sector while the private sector contains $6 \%$ disabled. $^{41}$ (Conservative estimates place the actual number of disabled to be $13 \%$ of the population). ${ }^{42}$ Other figures note that $52 \%$ of disabled persons are not in the work force although $23 \%$ are employable without retraining. Of the $48 \%$ in the labour force in $1986,6 \%$ are receiving unemployment insurance. ${ }^{43}$ The CCSD in a 1979 survey estimated a $50-90 \%$ unemployment rate among disabled. The Department of Health and Welfare has estimated the disabled unemployment rate to be as high as $85 \%$. In 1980 they also estimated that $943,(K K)$ were employable, 248,000 were temporarily unable to work, and only 159,000 were permanently unable to work of the well over 2.4 million disabled persons in Canada. ${ }^{44}$ Such would represent a disabled population statistic of over $52 \%$ unemployment. The final dismal employment figure comes from Gower (1986) who notes that while $62.4 \%$ of non-disabled are employed, only $27.6 \%$ of disabled are employed, and concludes;

"Regardless of age or education, disabled persons were less likely to have a job than those who were non-disabled. However the impact of disability on employment appears to be greatest for people with low levels of education." 45 
The general trend of inadequate social assistance levels holds true for disabled benefits. Although the following table is slightly outdated current amounts have the same purchasing power when cost of living is taken into account and may have even declined in relative advantage.

\section{DISABI.ED WELFARE ALLOWANCES ACROSS CANADA}

\begin{tabular}{|c|c|c|c|}
\hline PROVInCE & 1976/month & $1986 /$ month & 1988/month \\
\hline Mow found I and & 8180 & 3656 & $\$ 472$ \\
\hline Mova scotia & 8262 & 8467 & 8683 \\
\hline P.E. I. & $\$ 130$ & 8470 & $8602 *$ \\
\hline Hew Erunswick & $\$ 221$ & 8417 & 8460 \\
\hline Quebec & $\$ 217$ & $\$ 448$ & $\$ 488$ \\
\hline Ontarlo & $\$ 225$ & 8576 & $8693^{*}$ \\
\hline Manit toba & $\$ 186.40$ & $\$ 414$ & $\$ 461$ \\
\hline sackatcheuan & $\$ 75$ & $\$ 498$ & 8535 \\
\hline Alberta & 889 & $\$ 720=n$ & $8720 \mathrm{~m}$ \\
\hline British colombia & $\$ 265$ & $\$ 658$ & 8583 \\
\hline
\end{tabular}

- InCludes maximum shelter amd equiphemt alloyamce mistrict eliglellity

A more recent survey noted that $54 \%$ of disabled people have total incomes below 10,000 dollars per year. ${ }^{47}$ The following chart contrasting disabled financial income to non-disabled is constructed from figures produced by the recent Health and Activity Limitations Survey. 


\section{DISABI ED INCOME CONTRASTED WITII NATIONAL, AVIERAGiE:}

\begin{tabular}{|c|c|c|}
\hline Range & Disabled & Mational Average \\
\hline$-\begin{array}{lll}- & - & --\end{array}$ & - & $\cdots$ \\
\hline $1-4.999$ & $28.8 x$ & $21.9 x$ \\
\hline$\cdots \cdots$ & & \\
\hline $5.000-9.999$ & $34.6 x$ & $219 x$ \\
\hline$\cdots$ & & - \\
\hline $10.000-16.999$ & $16.1 x$ & $162 x$ \\
\hline ar -- & & \\
\hline $\begin{array}{l}15.000-19.999 \\
-\end{array}$ & $8.1 x$ & $11.3 x$ \\
\hline 20.000 .26 .999 & $6.1 x$ & $9.0 x$ \\
\hline$\cdots-\quad-\quad \cdots$ & & \\
\hline $25.000-29.999$ & $3.3 x$ & $7.0 x$ \\
\hline 30 non & & $\cdots$ \\
\hline $30.000+$ & 5.14 & $14.6 x$ \\
\hline
\end{tabular}

In this chart it is possible to see how the disabled are over proportionally portrayed at the lower levels and grossly under proportionally represented in the higher income ranges, thus graphically depicting a system of economic discrepancy and inequality between the disabled and non-disabled Canadian populations. The recent BOOST report noted on the topic that;

"The greatest barrier currently facing so many disabled people is the level of poverty they must coinfront. Like most other citizens, the bulk of disabled Canadians like to work and contribute to their communities. ...If urgent attention is not given to help disabled Canadians emerge from their deplorable standard of living, Canadians can expect to hear demands from the disabled for the enactment of a guaranteed annual wage that will ensure them a reasonable standard of living".

Not only do employment and financial indicators demonstrate a wide disparit! between disabled and non-disabled, but these figures do not take into account thi 
large number of other areas were disabled persons experience discrimination. Most employment statistics for example ignore persons below the age of 19 (6\% of disabled) or above the age of 65 (45.5\% of the disabled). In the previously referenced Gower conclusion, education is advocated as a means to elevate status. However, in actual fact only $17 \%$ of the disabled $15-34$ years old are full time students compared to $23 \%$ of the non-disabled. Proportionately, non-disabled persons rank considerably higher than disabled in terms of participation at all levels of education. ${ }^{\text {so }}$ A survey by Health and Welfare, initiated in 1981, notes that under educated Canadians including the elderly, women, the poor, disabled persons and sther minorities are damaging their health with current type of lifestyle. ${ }^{51}$ A recent report by BOOST noted that;

\footnotetext{
"Most school programming for disabled children was up until very recently, segregated in nature. Where mainstreaming has occurred the necessary supports have not been put in place and as such the quality of education is inadequate. 152
}

It can be concluded that disabled persons have been cut off from the educational system as a means for achieving greater social equality. State policy towird the education of disabled persons remains inadequate and possibly even counter productive. The following chart shows similar discrepancies between need and actual provision in the areas of employment, transportation, and education. ${ }^{53}$ 
LACKING PROVISION OF SERVICE TO DISABLED IN SEI.ECTLED AREAS OF NEED

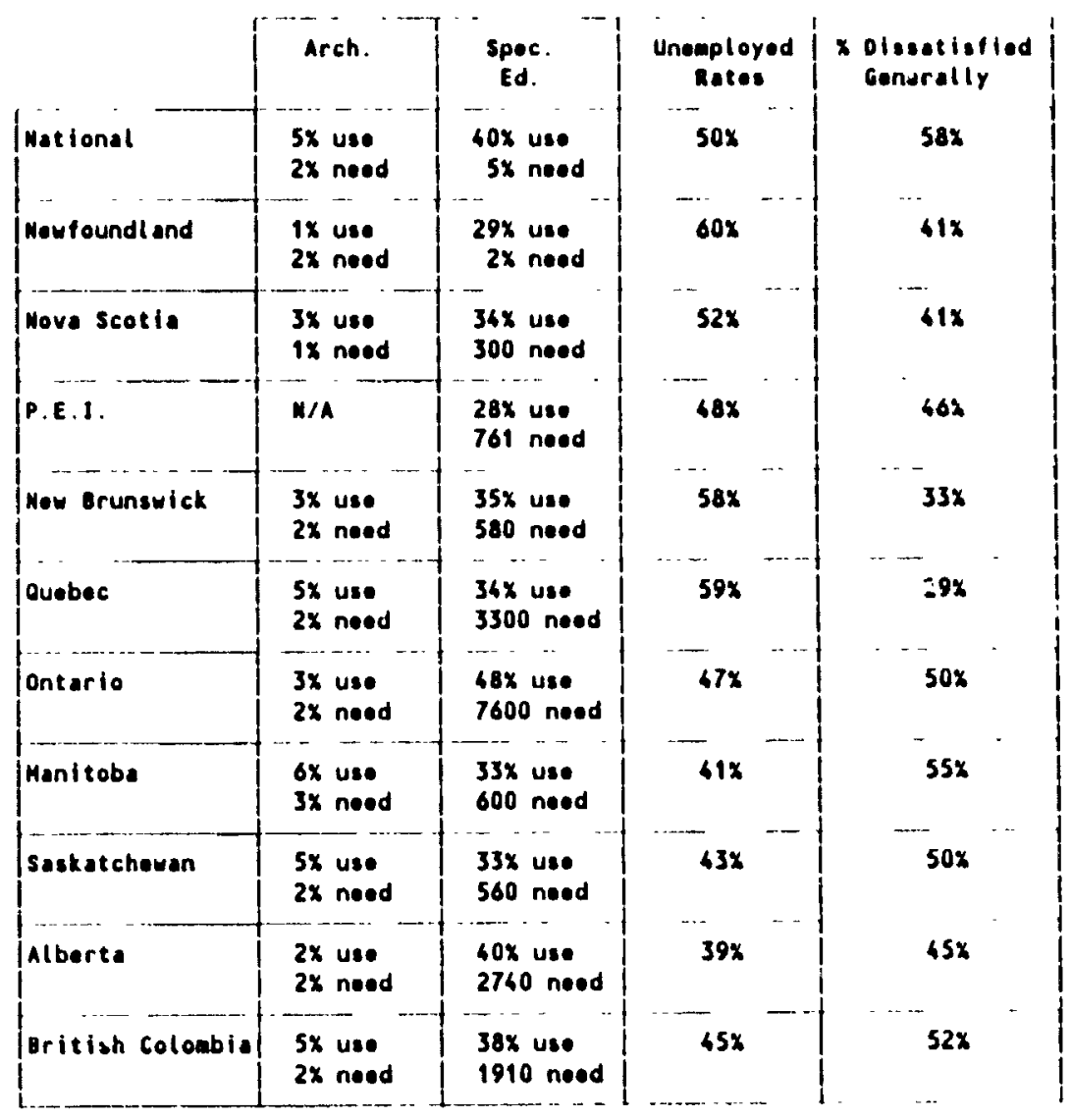

The list of unmet needs and discrepancies in equality can be traced from transportation (Ontario Advisory Council on Senior Citizens-1C87) through all asplects of societal living (Obstacles Report - Dept of Secretary of State-1981). The Ontario Advisory Council on Senior Citizens and the Ontario Advisory Council on the Physically Handicapped noted that "the lack of accessibility creates a handicapping environment and violates human rights." Statistics Canada found that at least $9 \%$ of the disabled had problems with travelling because public transportation was not accessible. In the recreation field, $9 \%$ also stated that they desired leisure activities 
but none werc available. Of the $35 \%$ of disabled adults surveyed; $65 \%$ said they were unaible to participate in available leisure activities; $15 \%$ said high cost was the major deterrent; and $10 \%$ claimed facilities and programs were insufficient. ${ }^{54}$ The recently published series of reports titled OBSTACI.ES, has exemplified to many disabled persons a perfect example of political grand-standing without realistically addressing the problem of inequality facing disabled persons. Regardless of such efforts, the common experience facing disabled persons still includes; arbitrary incarceration and suspension of human rights; forfeit of political rights, daily humiliation, decreased life expectancy because of institutionalized health hazards, segregating circumstances, loss of self-respect, and denial of self-determinism. All of these conditions exist despite the fact that, next to women and the native community, the disabled comprise the largest minority facing discrimination in Canada today. The following chart depicts the size of this category relative to the whole population. ${ }^{55}$

\section{PERCENTAGE OF DISABIEDDTOTAI, POPULATION}

\begin{tabular}{|c|c|c|}
\hline Year & $\begin{array}{l}\text { Disabled } \\
\text { Population }\end{array}$ & $\begin{array}{l}\text { Disablod } \\
\text { as a total }\end{array}$ \\
\hline 1967 & 650.000 & M/A \\
\hline 1980 & 2.325 .000 & $10 x$ \\
\hline 1984 & 2.400 .000 & $11 x$ \\
\hline 1985 & 3.500 .000 & $16 x$ \\
\hline 1987 & 3.300 .000 & $13.2 x$ \\
\hline
\end{tabular}


The Department of Health and Welfare noted in 1980 that $23 \%$ of Canadians had some sort of disability. The Canadian Council on Social Development report similar findings. According to available information regarding the relative stattus of disabled persons among all distinguishable groups, it is suggested that disabled persons fulfil all the criteria necessary to comprise a minority faction. ${ }^{50}$ Furthermore the evidence clearly depicts this minority group as being open to a great deal of societal discrimination. The disabled may be considered different from the dominant group, have diminished status levels as are gauged by various social, political and economic indicators, and finally are subject to obviously discriminating conditions such as charges of biological inferiority, segregation, stigmatization, stercolyping, confrontation with systematic barriers, and even overt bigotry. ${ }^{57}$

As Canadian social policy relevant to disabled persons does not in fact attempt to achieved equality but rather functions to meet the demands of the labour market by maintaining an impoverished reserve labour force. This process is greatly facilitated by the mistaken charity ethic ideology concerning the disabled.

In 1986 Patrick Johnston, speaking as a policy advisor for the Ontario Social Assistance Review Committee, pointed out the link between economic and social policy when stating that government policy has been transformed remarkably as a result of influences from societal conditions and events. ${ }^{58} \mathrm{Mr}$. Johnston was referring to the link between the government object of deficit reduction, and declining social 
programs in the province of Ontario. Historically this economic, social policy connection can be exemplified by analyzing the charity ethic intertwined with philanthropic organizations as the first official policy response to eliminating inequality in Canada. The actual objective of this exercise was to keep unsightly beggars off the street rather than to elevate status. Workers' compensation programs marked a noticeable improvement in perspective governing social programs since paymunts were granted as a genuine right and not tied to charity as a privilege. Iowever the economic policy influence was still apparent in this case since the real motive underlying these programs was to eliminate the need for costly and disruptive legal action. ${ }^{59}$ The most recent advancement in policy toward achieving goals of social equality came when Canadian Human Rights legislation was implemented and included minority status as being grounds for claiming discrimination. However, as will be expanded upon in chapter five the influence of ideology and economic policy may have nullified any potential gain to be achieved with such legislation.

In conclusion, the disabled in Canada are a diverse and geographically dispersed, socially, politically and economically devalued minority group. As a whole they are politically apathetic, under educated and poorly organized because of socially disabling societal attitucics and barriers. The needs of disabled persons have traditionally been met with limited gestures under the guise of good intentions rather then political will toward the provision of ordinary citizen rights or equality enhancing conditions. 
The discriminating circumstances of everyday life have endowed the disilled with diminished levels of self esteem, reduced confidence and thus cocdihility in the public conception. Disabled group membership characteristics tesemble all olle' immority group characteristics. Societal pressures have directed the public conscionsness to concentrate on individual esponsibility ather then the meed for social restructuring on a larger scale. The long tesm social-psychol ical impand al individual focus and devaluin. conditions has resulted in what appeans to be the willing acceptance of inequality by disabled petsons. As the socio-commmic (balp between disabled persons, who are ohjects of policy ditectives, and policy decision makers increases, so to does any chance of resolution. Piesent state sponsoned sondial policy is inclined to perpetuate the cycle of inequality though tic:s to connunic pulicy and mistaken ideological beliefs. The process of policy development, the comditions of psychological being, and other systematic barriess deter the expuession ol puactive policy capable of resolving social inequality facing minority groups. The policy development process as has been discussed so tar may be depicted similat to the following diagrams.

DIAGRAM I; Policy Develupment and Influence Process

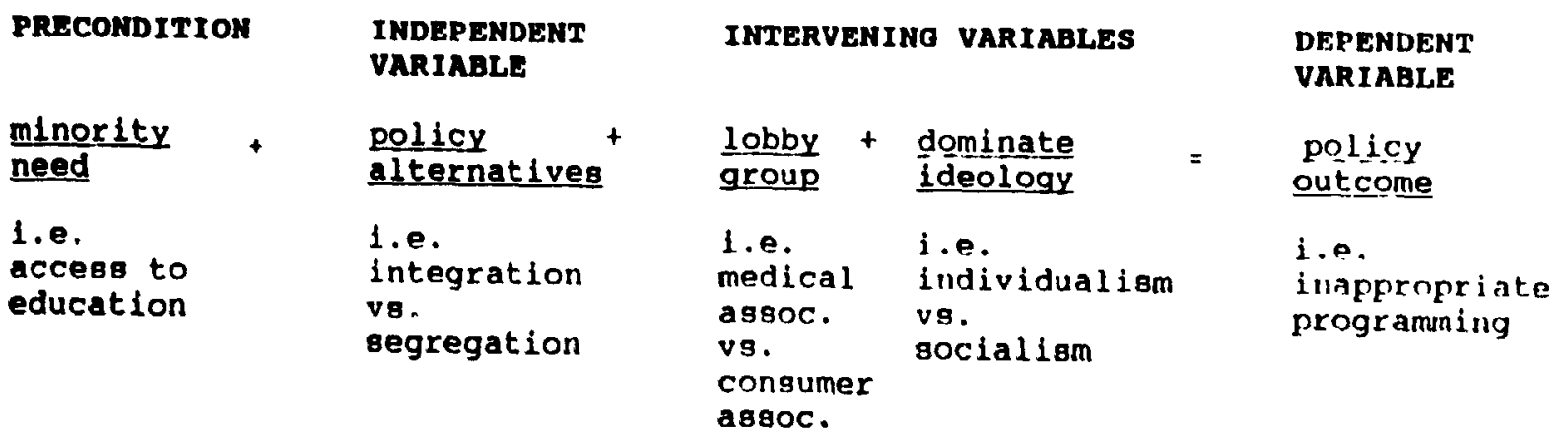


The dynamics occurring within the "Lobby Group" section can be magnified and represented in the following manner;

DIACiRAM II; Politics and Influence Between Societal Groups

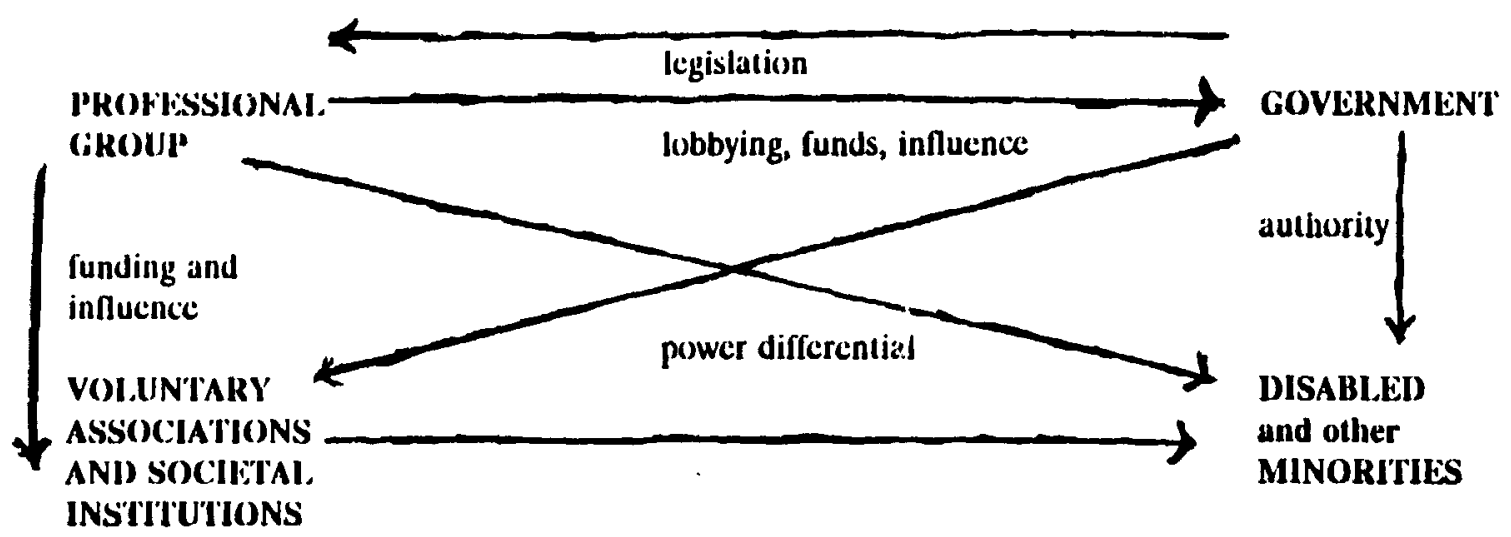

Corrective strategies, largely sponsored by leaders drawn from a certain social pool, have not proven effective and may even be considered regressive for achieving an outcome of equality. To understand Canadian social policy that creates and reproduces a system of inequality and how such can be rectified through more progressive policy it will first be necessary to analyze key shifts in the evolution of disabled policy. This exercise will help to uncover the strategies for social change to create new policy aimed at restructuring the social system. 
End Notes

24. Report of the Canadian Health and Disability Survey, 1983-84, Ottawa, Statistics Canada - I Health Division, July 1986.

25. Roy Hanes, "The Cripples Image; Issues of Dependency, Morality and Character", Unpublished Paper.

26. Monros: Berkowitz and William G. Johnson, Public Policy Toward Disability, New York, Praeger, 1976.

27. Douglas Biklen, The Culture of Policy, Disabled Images and Their Analogues in Public Policy, Policy Studies Journal, Vol XV, No. 3 March, 1987.

28. Table 5, Participation rate by disability, status, sex, and age group, Canadian Health and Disability Survey, Ottawa, Statistics Canada, October 1983-June 1984.

29. Tom Joe and Alan Gartner, Images of the Disabled, Disabling Images, New York, Praeger, 1987.

30. Harvey E. Adams, Abnormal Psychology, IOWA WMC Brown, 1981, Page 10-11.

31. Maureen Baker, The Disabled and the Handicanped, Ottawa, Political Science Affairs Division, 1987.

32. Harvey E. Adams, Abnormal Psychology, JOWA WMC Brown, 1981.

33. Joan C. Brown, A Hit and Miss Affair; Policies for Disabled People in Canadia Ottawa, C.C.S.D., 1977.

34. Table 13, Disabled persons by degree of dependence performing sveryday activities, by sex and age group, Canadian Health and Disability Survey, Oclober 1983-June 1984.

35. See for example; Tanis Doe, "Ontario Schooling and the Status of the Deaf: An Inquiry into Inequality, Status Assisnment and Educational Power", MSW Thiesis, 1988.

36.Louis Dikenson, "The Disabled; Breaking Down Some Barriers", The Ottawa Citizen, May 30, 1988. 
37. The Freedom to Move is Life Itself: A Report on Transportation in Ontario, Ontario Advisory Council on the Status of Senior Citizens, 1987.

38. In the 1988 Federal election mentally disabled persons were given the right to vote yet were still inhibited from doing so by systematic barriers, Globe and Mail Toronto, August 10, 1988.

39. "The Boost Report", Perception, Ottawa, Sept-Oct-1980, Page 22.

40. Maureen Baker, "The Disabled and the Handicapped", Ottawa, Political and Social Affairs Division, 1987.

41. Opposition Comments in House of Conmons May 7, 1987.

42. Ibid.

43. Table 3. Disability Status by Iabour Force Status, Sex and Age Group. Canadian Health and Disability Survey, Oct 1983/June 1984.

44. Statistics Canada Facts; Health and Limitations Survey, Ottawa, Statistics Canada, 1988.

45. D. Gower, Labour Market Activity of Disabled Persons in Canada, Ottawa, Labour and Household Surveys Analysis Division, Statistics Canada, 1988.

46. Earlier figures from Joan C. Brown, A Hit and Miss Affair, Policies for Disabled People in Canada, The more recent numbers were derived in a telephone conversation with a consultant at the Canadian Council for Social Development, Oltawil, C.C.S.D..

47. Canadian Health and Disability Survey, Ottawa, Statistics Canada-Health Division, 1983-1984.

48. 1leallh and Activity Limitations Survey, Ottawa, Statistics Canada, 1988.

49. The BOOST Report, Perception, Ottawa, Sept-Oct, 1980.

50. Canadian Health and Disability Survey, Oct 1983/June 1984. Table 2. Disability Status by Age Group and Current Education Level.

51. Disabled Persons In Canada, Health and Welfare Canada, Ottawa, 1980.

52. The BOOST Report Perception, Ottawa, Sept-Oct, 1980. 
53. Health and Activity Limitations Survey, Ottawa, Statistics Canada, 1988.

54. Wealth and Activity Survey, Ottawa, Statistics Canada, 1988.

55. Canadian Health and Disability Survey, 1983-1984.

56. Tom Joe, and Alan Gardner, Images of the Disabled: Disabling lmages, New York, Braeger, 1987.

57. Claims are validated empirically by contents of "Profile of Disubled Persons in Canada", Department of the Secretary of State, Nov. 1986.

58. P. Johnston, Submission to the Special Commitee on the Disibled and the Llandicapped, C.C.S.D., Ottawa, 1985.

59. Dennis Guest, The Emergence of Social Security in Canadia, Vancouver, University of British Columbia Press, 1981 


\section{PAGINATION ERROR.}

TEXT COMPLETE.

NATIONAL LIBRARY OF CANADA.

CANADIAN THESES SERVICE.
ERREUR DE PAGINATION.

LE TEXTE EST COMPLT.

BIBLIOTHEQUE NATIONALE DU CANADA.

SERVICE DES THESES CANADIENNES. 


\section{CHAPTER THREE: THE HISTORICAL, DEVELOPMENT OF CANADIAN DISABLED SOCIAL POLICY FOR THE DISABLLED; LESSONS IN SUCCESSFUL CHANGE EFIORTS}

Federal legislation is a complex result of chance events, intra-societal dynamics, and motivated by vested interests. Federal legislation in the realm of social policy is always a double edged sword having contradictory elements that bear witness to the influence of opposing class interests and reflect the struggle that has occurred. Such policies are therefore characterized by multiple objectives, sometimes self-defeating and other times totally unrelated. Legislation and policy for the disabled is not an exception to this rule. A historical analysis of public policy reveals that the circumstances of evolution and dynamics of development have given rise (1) basically antagonistic objectives. This helps to explain its ineffectiveness for achieving equality.

The small quantity of unrelated and uncoordinated legislation aimed at disabled persons represents the Canadian state's response to social inequality. Much is not worthy of consideration here since such efforts represents only token political gestures or are too minuscule to be representative of the era under scrutiny. Only certain pieces of legislation such as the War Veteran's Allowance Act (WVAA), The Blind Person's Allowance Act (BPAA), The Disabled Person's Act (DPA), and the Vocational Rehabilitation for Disabled Person's programming agreement (VRDP), will be examined in any great detail. Each of these represent a suitable example of state reaction to the demands of the disabled at varying points in time. Paralleding 
state response and the evolution of policy for disabled persons most legislation can be broadly categorized as one of the following; income maintenance, rehabilitative/integrative, preventive, protective or equality enhancing. Objectives related to these policy phases include buying off, assimilation, extinction, paternalism and finally promotion of equality, respectively. Early policy endeavours tended to be motivaled by charitable income maintenance directives (1900-1950's), having the effect of buying off disabled militancy. Overlapping the end of this era policies became characterized by goals of rehabilitation/integration (1950-1960's) thus catering to the demands of the economic laiour market. The late 70's and early 80's saw the addition of preventive and protective measures ágainst discriminatory societal practises. All policies to date were underpinned by a philosophy of extinction whereby disability was either to be avoided or corrected. Finally current policy is a mixture of all previous policy ploys but emphasizes equal rights yet lacks provisions to implement and solidify full social equality. The latest policy direction has not recognized that additional requirements are necessary in the immediate and ongoing stages and therefore does not allocate the financial means necessary to alter material conditions and allow the disabled to fully access and participate in society. Focus on rights does however represent a significant step in the battle to achieve disabled equality and therefore may serve as an example to be studied and analyzed in the quest to develop future change strategies. The case in point is the recent amendment to human rights legislation in 1983 which will be the topic of discussion in chapters tive. ${ }^{01}$ 
In this chapter the War Veteran's Allowance Act (1930) is used for analysis because it represents the single most significant example of early institutionalized response to disabled needs. it highlights the role of the influential disabled veterans group in procuring change. The role of charitable paternalistic ideology in altering the real intention of the Act is also discussed. The WVAA may be considered a cornerstone in the movement to achieve progressive disabled social policy. The next two pieces of legislation examined are the Blind Persons Allowance Act (1951) and the Disabled Persons Act (1954). These illustrate the post war state response to demands from two different segments of the disabled population. The most salient features of these policies are elements of social control and other contradictory objectives that effectively nullify any real beneiit to the target population. These two acts have since become obsolete because most provinces have opted instead to use provisions of the Canada Assistance Plan (1960), to perform the same functions. Regardless of the legislative authority, the same principles and basic value premises apply. Finally, VRDP (1961) legislation is examined since it represents the extreme influence of capitalist ideology, motivating the shift from charity to rehabilitation (disempowerment to assimilation). Each example analyzed is considered a landmark in the struggle to achieve disabled equality and thus the successes and failures may become a tool of future guidance when attempting to achieve or hasten the final desired end. The following is a chronology of policies related to disabied persons and depisting the struggle for disabled equality so that the reader may visualize the place and historical significance of the noted examples. 


\section{CIIRONOLOCIY OF SOCIAL POLICYIOR TIIE DISABLLYZ}

1840. 20 "Acl of IJaion" (UPC)

1840- Mentally ill and retarded are tuken into goals, hospitals and other public instilutions. (ON., Que., N.B., N.S..)

1841. Fint asylums for the mentally ill, Saint John-1836, and Toronto.

1849. Royal commission on Kinguton Penitentlary (U.?.).

1857. Prison Inspection ACA (IPC)-, aulhorized the catablishment of prisons for criminal lunatica. 1870, pensions eatablished for civil servants.

1870. Finst institution for the denf-Bkellevillc $O N$.

1870. First institution for the mentally retarded, Londan ON..

1872. First institution for the blind, Branion ON..

1874. "Charily Aid Act", ON., fint act authorizing grants in ajd.

1874. Compensation to families for accidentwl death, Dom..

1887. Railway Accidenis Acl, Dom..

1887. Pension Fund Soxieties Act, Dum.

1888- Training school tor mentally retarded children, Orilla ON.,

1888. "Workman's Compensulion for Injuries Acl", ON

1890. "Ilouse of Rufuge Acl", ON., appearance of fira legislation with powers to help the aged.

1897. Public support for mental hospisus, B.C..

1897. Lunatic Asylums and Custody of Insane Persons, ON..

1900. Report on Workman's Compensation, ON..

1908. Commissisner of Feeble Minded appointed, ON.

1908- "Government Annuitics Act", ON..

1908. Census of leecble Minded, ON..

1909. "Act Respicting Industrial Accidemts", Qu .. 


\section{CURONOLOOY OF SOCIAL POIJCY LOR TIIE DISAIM IED}

1916. Royal Commission on Faeble Minded, N.S.. 1916,

1918. Workman's Compenestion ACI, B.C.. Alta. + N.B., Man.-1920, Quc.-1926, Sask.-1929.

1917. "War Chantica Acl", Doas.

1918- "Soldiers, Cival Reestablishmwat Act", Dom.

1919. Royal Commission on Mental Defective, ON..

1925. Royal Commission on Mcnlal Ilygenc, B.C.

1926- "Act Reapecting Prychiatric lluspitals", ON..

1927. "Old Age Pensions Act", Dom.

1930. "War Veteran's Allowance Acl", Dom..

1935. "Mental Iloxputal Act", ON

1936. Que. opts onto pension Act

1937. Pension Act is amended to extend pensions lu blind persons age $40+$, Dom..

1943. Increase in blind persons pensions, ficd.

1944- "War Service Grants Act", Fed.

1944- "Department of Veteran's Aflairs Act", lied. .

1945- "Veterans Rehabilitation Act", Ficl..

1946. "War Veteran's Allowance Acl", Fed.

1947- Old Age Pensions Aat amended to include blind $21+$ Fed. 18+-1957.

1947. Fed.-Prov., Mental licaly Girant.

1948. Pension Act Amendiments, Fed..

1951- National Advisory Council an Kehabilitation, Fied..

1951- Major revision of the Pension ACl, ticd..

1951. "Blind Persons Act", Fed.

1953. "Old Age Assislance Acl", Fed

1957. Increase in Disabled Allowance, Fed.. 


\section{CIIRONOIOCFY OI SOCIAI POI.ICY FOR T7 HE DISABI ED}

1961- V.R.D.P. Act Fed..

1964.65 "Latablished Prograns (luteam Agrecments) Ad", Fid..

1905. "Canada Pcusions Act", I'cu.

1960- "Canadu Assistance Plan Acl", lied..

1966-67 "Rension Ben:fits Standards Act", Fed..

1\%67. O.A.S. Acl amended.

!967. "Canada Manpower and Immigration Act", Fed., rep'aces National advisory council on Rechabilitation.

1971- U N. declaration of the righes of anentally relarded puivos.

1972. "Federal. Provincial Fiscal Arrangements Act", ticd..

1973. U.S. Rehabilitalion Acl provided for protection against discrimination on grounds of plysical or mental disibility. Canada follows suil ten years later.

1974. Canada Pension Plan Act anended, Fod.

1974- "Fumily Allowances Act" ted. 62

1980. U.N. declaration of the rights of disabled persons.

1980. House of Commons special Commuttee on the Disabled and Handicapped is calablished.

1981. International Year of the Disabled proclaimed.

148i- Disabiluty is included in the Canadian Bill of Rights and Ijecdums as grounds for discrimination.

148:- A national policy for transpontation of the disabied was adoptcd by parlianent.

1983-86 The Bill of Rights is significantly amended and entrenched in the Constitution "Employment Equaty Act", introduced.

1988- Comprebensive "llealth and Activity Limitation Survey" is completed by Statistics Canada. ${ }^{63}$ 
The chronology above depicts an evolution in ideology toward disabled persons. The period throughout the 1800's is characterized by incarecration often with convicted inmates. At this time being disabled was considered criminal according to the consequence of the prevailing incarceration policy. Toward the beginning of the 1900's policies becams more employment sector oriented to reflect the need in the work place brought about by the rapidly expanding industrial economy. The first half of the 1900's was characterized by state sponsored chanily able to persons disabled during war time, and later expanded to other disabled persons as a means for pacification. From 1960 to 1980 a number of labour force oriented and pension programs were introduced. Finally from 1980 onward the focus of government initiatives was switched to provision of rigints without tinancial or enforcement commitment.

In this evolutionary depictoon of social policy for disabled persons many additional observations became apparent and are worthy of mention. Each policy is only a minor variation from prior action or a copy of legislation enacted in Britain or the United States. Most of the significant alterations occurred between 1926 and 1961, when the disabled population was growing both in terms of status, size and power. This phenomenon occurred in concert with two world wals and a long economic depression. The resulting massive social upheavals altered attitudes, jodeologies, traditions, and roles of societal members on a grand scale. Disabled persons', numbers and power was radically enhanced with the addition of returning 
veterans. During the absence of the regular male labour force, disabled persons and women realized their true potential as productive, contributing and equal members of socicty when entering the labour force. Women could no longer be expected to take care of disabled family members at home and mariy of the disabled could no longer be expected to stay home. Emotional appeals for the inclusion of disabled persons into society were supported in contrast to, and partly in spite of the Nazi use of termination camps for disab:id people.

During the depression years notions of deserving and undeserving poor became blurred and incentive was derived for expansion of the welfare state. The rise in industrialism, combined with increased capitalist profit motive and rapid tcchnological advancements resulted in a larger number of persons disabled in the work place. The economy was caught in short boom-bust cycles and the public soon realized that massive government spending was not only possible but also such intervention was desirable. ${ }^{65}$ The role of the state as a stabilizer of the economy and thus protector of the status-quo seemed to be given incentive by hostile events in Europe. The depressed global economy of 1913-14 contributed to the Russian revolution and the first world wer. Peace time brougl.t demands for social change in all areas of society. The government engaged in the massive social spending as a means to artificially inflate the economy during periods of economic depressions. David Wolfe argues based on government spending records that the Canadian Government employed Keynesian ideas between 1930 and 1982 to stabilize the 
private market. ${ }^{\infty}$ Higher social spending, was preached under humanita jan premises by Harry Cassidy, and in the Beverage and Marsh reports, increased funding dramatically. In the 1940's the research of Harry Cassidy in Toronto and lenand Marsh in Montreal raised many questions about inadequate health carc provisions, housing income, and high unemployment rates. Their work advocated the creation of social insurance legislation. ${ }^{67}$ The following is a representation of such Canadian state financial intervention into the economy from 1866 to 1939 . Government spending increased dramatically over this time period in absolute terms and relative to the Canadian gross national profit.

\section{STATE EXPENDITURE IN PUBI.IC WEI.FARI: ${ }^{\text {iK }}$}

\begin{tabular}{|c|c|c|c|}
\hline year & $\begin{array}{l}\text { Total Welture } \\
\text { Expenditures } \\
\text { Milltions : }\end{array}$ & $X$ of GOVERHMENT & $x$ of G.M.P. \\
\hline 1866 & .5 & 3.2 & .12 \\
\hline 1874 & .9 & 31 & .18 \\
\hline 1896 & 2.6 & 125 & .23 \\
\hline 1913 & 15.1 & 207 & .64 \\
\hline 1926 & 99.0 & 225 & 1.90 \\
\hline 1933 & 2305 & 267 & 660 \\
\hline 1939 & 317.2 & 27.1 & 5.90 \\
\hline
\end{tabular}




\section{WAR VEIERAN'S AIJOWANCE ACT (1930)}

Historically ambivalence on the part of the Canadian government towards rewarding soldiers disabled in war has been documented. ${ }^{69}$ The reason for state ambivalence is that disability and thus exclusion from the labour market, is the signal for the application of discriminating conditions. A significant step toward resolving state indifference occurred after the first world war and set the stage for measues to come. However this measure could more realistically be attributed to the existence of a certain set of social conditions rather than motivated on the premise of creating equality. The Bill known as the War Veteran's Act was assented to on May 30th, 1930, the same day that Prime Minister MacKenzie King called a federal election. This period was also marked by what has come to be known as the "Great Depression", and the rise of political left wing parties like Cooperative Commonwealth Federation. All of these factors combined to precipitate an increase in social spending. ${ }^{70}$ The timing of this policy's introduction is especially interesting given that the government had considered such action for a long period of time yet even in the fice of well documented need had been reluctant to act. During initial presentation at the first session in the House of Commons the many contradictory clauses contained within the Bill were made apparent. For example, poverty as a requirement of eligibility, placement of proof upon the individual to prove unemployability, lack of appeal mechanisms, exclusion of surviving dependants from benctits, and political control of administrative machinery, were dominant 
characteristics. A number of these regressive conditions make reference to elements like: "deserving poor" categories, minimal subsistence-assistance levels, residual notions of welfare relief, labour market relative eligibility requirements, and the obvious presence of financing according to state priorities. ${ }^{71}$

This particular state response was given public justification through the lobbying efforts of groups like Royal Canadian Legion and especially through the influence of General Arthur Currie. ${ }^{72}$ Rationale for implementation of this measure was most often advanced on the grounds of filling gaps left by Old Age Pension legislation. ${ }^{73}$ The need was demonstrated in the House of Commons in the words of Mr. Labner when he stated; "Grievances have been accumulating throughout Canada for some considerable time". ${ }^{74}$ The initial target group was estimated by another M.P. to be in the thousands and expected to cost two million dollars in the first year of operation, peak in 1958 at a cost of 18 million, and cease to be required around the year $1980 .{ }^{75}$ In retrospect, the accuracy of these estimates gives tesiimony to the great deal of effort that went into planning this project and possibly provides evidence of state commitment to control and restrain the measure. In tact, at the peak of the program in $1950,26,243$ veterans received a total of 16,500, , $10(1)$ dollars. ${ }^{76}$

The cost of benefits authorized under this legislation represented a signilicant financial commitment on the part of the state. However, the cost was compensited by the political support of a large proportion of the population; the expanding class 
of veteran's and their supporters. The initial policy refers to the government's intent to maintain tight control of the Act, including efforts to dictate comprehensive contents, and insistence on control over the review committee. R.B. Bennett, then leader of the opposition, complained that government and committee, ideology and membership, were one and the same. As such the government would continue to specily the contents and nature of implementation proceedings under the guise of democracy. The advantage, other than financial, for maintaining strict state control over conseguences arising from this policy was to insure political patronage and party aftiliation. $^{77}$ The Act thus gave the relevant pension board a large degree of discretion in the administration of their duties, but only relative autonomy from the Department under the supervision of the Minister. Opposition members frequently Icvelled charges that a covert board objective was to restrain funds for the purpose of securing partisan political support. The Veteran's Allowance Act, in view of this political agenda, went through a large number of amendments since it's inception. Many sections simply reinstated similar previously repealed segments, but as a general rule changes tended to be liberal in the 1930's, geared toward control in the 1950's, and have recently again become relaxed, all subject to the availability of finances and state priorities. ${ }^{78}$ By third reading all political parties were satisfied with the final product providing evidence of the prevailing dominant jdeology in all state decision makers regardless of party membership. The original policy and subsequent modifications rellect the influence of social conditions and the underlying mistaken ideology. 
The issues dealt with under this agrement concern with the rights of disabled veteran's to receive compensation for war time service which has resulted in the inability to be self sufficient for what ever reason. The policy was completely inadequate with regard to issue of provision of the means for disabled persons to become equal. As such, the parameters of this policy include the quality of life and circumstances of living for disabled veterans and veterans over the age of 0.5 .

The covert objective for introducing this policy may have been to pump up the economy at a time of capitalist economic crisis and probably to enhance the state image as a benevolent, legitimate societal ruler. The promoted objective was to fill gaps in the existing pension scheme and to justly compensate returning soldiers for military service. However the underlying intention of such action may have been purely politically motivated. Only veterans who had served in a "theatre of war" were targeted as beneficiaries. This group was increasing in size, visibility, and power through growth in numbers and "unionization" in organizations like the Royal Canadian Legion. The same group was also expected to decline linearly up to obsolescence in 1980. Short and long term political gains could be expected for the party in power while costing little and providing only marginal benefits for target populations. No significant quantitative change or alteration in priorities could be expected from this policy outside of a qualitative difference in societal acceptance of state sponsored payments to persons of employable ages yet outside of the labour force because of situational difficulties. 
This Act does represent the legal codification of the right to financial benefits outside of those allocated by the market system to a previously ignored category of disabled persons. However the specific directives contained within the legislation nullify any real gain in civil rights for this class of people. The greatest benefit from this legislation was likely not felt by the individual receivers but rather by the economy as a whole since it was slightly inflated when the joint impact of the many social programs is considered. Other members of society may have more deeply institutionalized a charitable opinion of the disabled and the elderly while building confidence in the state for resolving social problems. The perceptions of the 30's set the stage in the fifties for the development of charity based, labour force dependant, disabled legislation.

\section{TIE BLIND PERSONS ALLOWANCE ACT (1951)}

Government welfare payments for blind persons were first introduced on an ad-hoc basis in 1936. ${ }^{79}$ By the 1950's general disabled policy in Canada was characterized by; rehabilitation benefits, institutional care, work institutions, public entitlements, growth in medical and charitable organizations, and growth in specific advocacy organizations like Canadian National Institute for the Blind (CNIB) and the Canadian Paraplegic Association (CPA) ${ }^{80}$ Allowances for Blind Persons were completely institutionalized in Bill 396 which came into force January 1, 1952. This cllort, along with a large quantity of other social legislation passed during this era, 
was short on substantial gain for beneficiaries, long on political mileage for innovators and primarily designed to stabilize the economy in a time of economic recession. Between the Act's introduction by the Minister responsible for National l lealth and Welfare on June 15,1951 and the first reading six days later, opposition parties rightfully found fault with the restrictive criteria for eligibility, which stated that a beneficiary must be totally blind having less than $10 \%$ visual acuity, over the age of 21 , and in financial distress. ${ }^{81}$

Under the authority vested in this act a blind person could receive a maximum benefit of 40 dollars per month (up from 30 dollars under previous arrangements) of which the federal Government was to contribute $75 \%$ and the provinces $25 \%$. The measure was introduced to concur with reforms made to the Old Age Pension Plan. Some evidence does exist that this alteration was largely inspired by pressure from advocacy groups since the Canadian National Institute for the Blind and the Canadian Council for the Blind made a six point program recommendation in $1947 .{ }^{.2}$ In this submission it was proposed that io residency requirements, a broad definition of blindness, minimal eligibility restrictions, and no ceiling on allowable carnings be included. In other words, the benefit was to be distributed as a right and not as a privilege based on need. Introduction of the actual legislation only altered existing policy by minimally increasing the allowable carnings and slightly relaxing cligibility and residency requirements. 
At the time of enactment it was estimated that 11,000 blind persons between the ages of 21-69, of 18,000 total blind Canadians would benefit. During the second reading on June 23 , it was suggested that in addition to those already covered by the Old Age Pension Plan only 2,000) to 3,000 new persons would benefit, of the 7,238 people to receive blind allowances. The maximum increase in benefits that some would receive under this new category would be 120 dollars per year, prompting opposition charges of government grand standing by exaggerating the net real income change. However as a whole politicians across all party lines supported this endeavour and their collective sentiment was echoed in the words of Mr. Martin during debate.

"Every Canadian can feel proud that through this measure he is doing something to help those of his fellow citizens who bear this heavy handicap ${ }^{183}$

The covert objectives were sinilar to those of other cost shared social legislation developed during the period in that social control and the furthering of state influence and involvement into private affairs was evident. While section 7 of the act delegates administrative responsibilities to the Provinces, section 10 and 12 give the Federal Government authority and control, including the all important ability tw make regulations regarding the definition of blindness, Provincial procedures, application investigation procedures, and definition of residence, for example. ${ }^{84}$ Bencfits were granted under the Act only on condition of individual forfeit to the 
right of privacy according to section 7 and $11, d$. An additional elememe of social control can be presumed when viewing the adequacy of benctit level. Minimal levels provided for in the legislation are assured to keep recipients peor through low allowable earning thresholds (sec. 2e) and strict property ownership and transfier conditions (sec. 7c ix). For example, the maximum possible income, including allowance benefits, for a single unmarried recipient was 1,320.40 per year.

Finally, according to the Keynesian tactic regarding social spending as a means to stabilize the economy by averting potential economic crisis arising from cappitalist over production and under consumption, this program was also casily justified on economic grounds. The following charts depict government spending for blind allowances both under the prior Old Age Pension scheme and the Blind Persons Allowance Act.

TABI.E 1: Pension Payed for Blindness, September 30, 1949

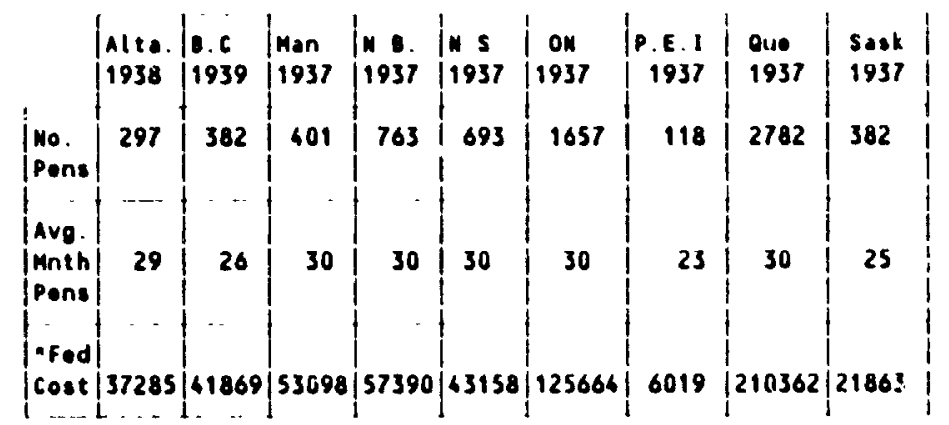

- Huch of the faderal money came trom specially eer merked funds set up und - the War Moesures Act ged were listed as "War Appropriation. Mar Expendlture. Oemoblllization Appropriation and Conversien". 
TABLE 2: Blind Persons Act Pensions, 195?-53 ${ }^{86}$

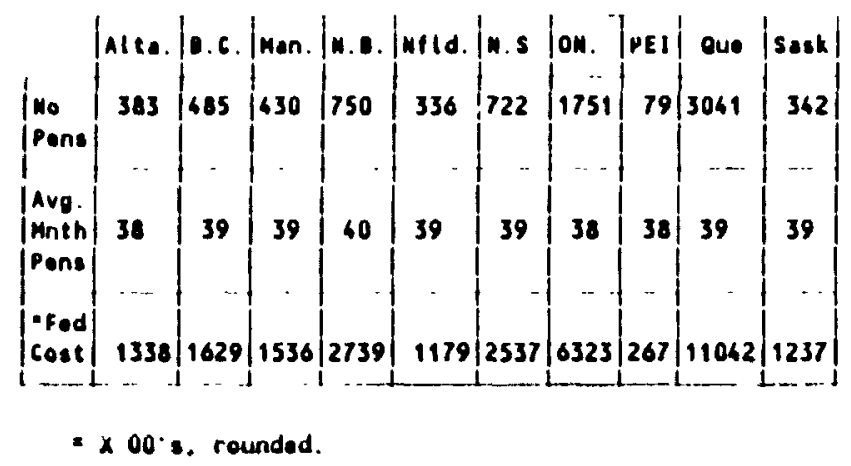

When changes in cost of living and inflation are accounted for very little difference can be observed between these two charts. Thus it is plausible to understand the implementation of this legislation as being a state reaction to advocacy group pressure with minimal real change. Other government actions of the time also represent governmeilt response. For example, in 1951 grants to the CNIB increased from $\$ 18,(0) 0)$ (1) \$45,(K)(1)/year and in 1956 a 3.5 million dollar rehabilitation centre and head office was built for the organization in Toronto. ${ }^{87}$ Such responses effectively bought off the group's militancy and also promoted government objectives in exchange for funding. In actual fact, the same amount of money was being pumped into the economy to avert crisis, while producing a positive state inage and insuring better control. Retention of residency cligibility requirements (sec.2 iii and 7c v) have the covert desirahle objective of insuring that funds remain in the country and thus most effectively address the problem of polential depression. Also government sponsorship of charitable organizations indirectly fulfilled a state function of individual social control since such organizations have been proven to incapacitate individual ability while simultaneously empowering the giver. 
Similarly the door is opened for the state to delegate public welfare to the private sector. In retrospect this appears to be the case as the current situation is characterized by increasing delegation to private sector, while non-profit charities function essentially as agents of social control.

To summarize, the nature, scope and distribution of issues relevant to this policy concerns rights distribution especially in terms of tinancial security for one segment of the disabled population. The broader issue is one of social inequality and total rights allocation. Various theories may be useful for analyzing this policy. The most plausible theory conceptualizes the state's chicf functions as being a mediator of class conflict, stabilizing factor for the economy, and protector of the capitalist economic system. In addition, such coniditions ind cate the existence of an English poor law philosophy, whereby charity is given sparingly to the deserving poor. Thus strict eligibility criteria, minimal benefits, and conservative motives prevail. The ¿insequences of ideological o entations and hidden objectives have inhibited substantial changes but created large public relations gains for the state. Inadequate benefit levels serve to impoverish and control recipients by applying the same socially instilled and individually registered disabling circunstances as are common to all low income individuals. As a result, any pussibility of mobilizing for change is reduced. The policy could be predicted to enlarge provincial bureaucracies and thus further produce social control and alienation. Fintally the nature of intra-societal human relations would predictably remain unatered by the deeper entrenchment of a maligned prevailing ideology. A major problem of this policy 
concerns the misdiagnosis and poor targeting of the dis.bled groups needs. Insistence upon an absolute unemployable definition of disability not only excludes a large number of other ,eople out of the work force and in need but also misdirects the fical point of the intervention to dwell solely upon the individual.

\section{DISABLED PERSONS ALLOWANCE ACT (1954)}

Disable Persons Allowence Act, was a Federal initiative 'unded in conjunction with the provinces. It may be seen as being truly representative of contemporary government policy toward physically disabled persons. It was assented to on June 26, 1954, the lasi day of the longest parliamentary sitting to that point in the history of the Canadian government. It came into force on January 1, 1955 to fulfil election campaign promises made before the previous election, ${ }^{89}$ and thus the policy may be viewed as an attempt to maintain political power by being perceived as a legitimate ruler governing in the best ialerests of all the people. The act underwent a series of small amendments up until December 1, 1983. Presently, most provinces have opted to utilize the Canada Assistance Plan Act rather than this piece of legislatom. ${ }^{91}$ This most recent alteration again occurred on thre eve of an election. It is interesting to note for future refereace, that during the same year of the policy's original presentation (1954), a private members bill suggesting the introduction in Canada of all inclusive bill of rights was soundly defeated. ${ }^{92}$ 
A closer examination of the original policy and the circumstances of evolution reveal that while the bill was premised upon humanitarian principles to provide aid for a previously neglected group of citizens as was already exemplified and precedented by Veterans Allowance Programs and the Blind Persons Allowance Act, it was also guided by a philosophy of charity, strong government intervention related to the requirements of the labour market, and other elements of social coritrol.".3 The final icsult of such regulations upon the targeted group of recipients in particular was a diminished capalcily for a social participation because of lowered self esteen, forced dependency upon minimal and inadequate benefits, and otherwise socially imposed restrictions. The prime objective of this policy was to care for the recipient in a paternalistic fashion rather than directly confront the problematic conditions at the base of inequality facing disabled persons. To effectively resolve the problems encountered by the disableal would necessitate challenging some of the most basic notions founding a capitalist system. Thus the provision of a minimal allowance can be viewed as a trade off for establishing basic civil rights that guarantec equality and opportunity to fully participate in socicty. The method of responding characterized by this policy can be labelled liberal reformism.

The historical events leading to the development of this policy included society's mentality arising from Victorian philosophy conducive to the provision of chanty eclict to those considered to be deserving poor, workers compensation programs designed (o) stabilize labour relations in times of individual-industrial crisis, and a number of ad hoc programs inspired by the eveats of two world wars. These two wats wede especially 
important in the development of such iegislation since they provided the catalyst for a host of related social changes including; a rapid expansion in both the use and development of technology; a temporary change in sex stereotyped roles; a large increase in the degree of government intervention and spending into private affairs; a large increase in the callegory of persons considered to be disabled and consequently a Moportional advancement of their political and consumer power; destabilization of society oIl a mass seale; the apparent importance of a reserve army of labour and the fragility of socictal and industrial relations during a world crisis. ${ }^{44}$

This policy was largely inspired by and resembled the Blind Persons Assistance Act 1951 and was promoted actively, although in a different form, by special interest organizaltions like the Canadian National Institute for the Blind, and the Canadian l'araplegic Association. ${ }^{45}$ Pressure from a number of other non disabled groups in this respect was also apparent. The International Society for the Welfare of Cripples, various facliems of the (ieneral Assembly of the United Nations, The World Health Organization, the Intermational Refugete Organization, and the International Labour Office all advocated on iehall of such action. The most active organization in terms of submitting actual recommendations to parliament regarding format such policy should pursue was the Canadian Wellare Council as early as January 19, 1954. The following is a summary of their ecommendations which were subsequently ignored for the most part. 
A rehabilitation component should include, distinctions betwecon disabled and handicapped to address the role of:

"economic conditions, employment possibilities in the locality, the attitude of the public and the availability of rehabilitation services."

Definition of disability should take into account the wide degree of individual variation in terms of motivation and type of work environment. Their proposal nostes that many people considered disabled have been made so by neglect of a rehabilitation component. They also recommended; residence requirements and mobility restrictions be open, age limitations be lifted, benefits should be expanded to include additional costs of disability and adjusted for regional economic disparity, allowable income from other sources should be maximised and not include soutces granted to other members of the family, application should not be means tested, appeal process should be put in place, benefits should be distributed according to three categories; *

1) "Disability Allowance"- given to persons who cannot be rehabilitated

2) "Rehabilitation Allowance"- 10 maintain the person while undergoing training

3) "Maintenance Allowance"- to supplement the salary of working poor disabled who do not fit into either categories 1 or $2 .^{97}$

The submission offered by the Canadian Welfare Council is obviously progressave when contrasted with the actual policy, by virtue of including the notion of social and 
cnvirommental impact, yet it is faulty in that all proposals are tied to the labour market. Inclusion of labour market requirements only serves to compliment the mistaken prevailing cappitalist ideology and sublime the real issue of inequality. Regardless of the aclual focus, the proposed progressive elements were intentionally over looked by legrslation while portions corresponding to hidden state objectives were included.

The policy made reference to by this act identifies the issue to be addressed in the remedial effort as one of income maintenance to persons incapable of providing for themselves because of individual physical limitations imposed by severe and permanent disability. "The benevolent spirit of this act is a reemergence of the "deserving poor" charitable relicf principle codified in the English Poor Laws. Preliminary input from advoxacy agencies of the target group in question established socially progressive elements whlc business and government interests nullified any possible real benefit through the iurposition of social control regulations and profit motivated enphasis. For example, such interest groups supported the inclusion of means tested components. ${ }^{\text {"d }}$ This ready acceptance of this type of policy may have been made possible by the timing of its intuoduction. The western world had recently been subjected to two world wars but had actained the prosperity to engage in the task of restabilizing society and rewarding disabled veterans. Decision makers recognized of the high utility value of haveng a secondary trained reserve army of labour to be readily activated when the regular work force needed to be shifted to military duties elsewhere. Regardless of the many motivations that cumulatively fuelled the misguided apjoroach of income maintenance 
taken hy this policy, the real issues of sicial equality through equal rights and opportunity distribution were ignored.

The stated intention of this act was to provide severe!/ and permantently disabled persons with a minimal subsistence level of relief." Upon reading father into the Act covert goals become apparent including: support for family structures (first reading, May $24,1954)^{100}$; intervention and social control of provincial areas of justilication as were previcusly granted in the BNA Act (Section 7 VIII, Disabled Persons Act 1954); and direct, obvious objectives of social control and infringement of personal rights to confidentiality (Section 6, Disabled Persons Act, 1954). Additional covent objectives maly be deduced when investigating the contents of relevant regulations. Regulations are developed by the administering departments and are designed to direet and specify the exact implementation process of the general teims contained within the Act. Such directives were formulated to specify: a definition of severely and permanently disabled; administrative arrangements on all counts; application forms; investigation procedures; residency requirements; definition of allowable incone; detinition and scope of allowable property assets; circumstances of distribution; and conditions of bencfit forfeit and recovery. The nature of these regulations are inherently restrictive and inhibiting upon both the intended purpose of the policy and the individual recipient. For example, Section 3, Subsection 2Il, authorizes mobility and residency requirements that ensure accountability of subjects and thus perform a function of social control. fincome allowability restrictıns guarantec that the recipient is not only poor upon application, but 
also remains impoverished there afterward (see Section 3, Subsection 2, and Section 7 IX). The rather complex and comprehensive definition of disability contained in regulation ensuses that only a very small number of people will be eligible for benefits while systematically excluding social circumstances as a factor and ironically including both inability to enter the labour market and entrance into the labour force on demand as conditions of successful application at. : continued receipt.

A person may qualify for benelits under the disabled persons act if they meet the following conditions;

"(a) is suffering from a major physiological,anatomical, or psychological impairment, verified by an objective medical finding (b) the impairment is likely to continue without substantial improvement during the life time ofthe person and is one to which the concept of cure cannot be applied and (c) as a result of such impairment the person is severely limited in activities pertaining to self care and normal living such as being (i) bed ridden or chair fast; (ii) unable to leave home without being accompanied by another person; (iii) normally in need of care and supervision for one or more of such self care activities such as dressing, bodily hygiene or eating; unable to perform such routine activities as eating; unable to perform such routine activities as climbing a short stairway, walking a limited distance on a level surface or (v) verified by a qualified physician to be under medical instructions to forbear from routine activities such as the kind mentioned."101

Using this definition, which denies the role of societal conditions and the use of technical aids and/or normalized paid attendant care services, approximately between 20,000) and 25,(60) people could be considered severely and permanently 
disabled. ${ }^{102}$ However the target group was likely to be much higher in 1954. At present, over 2 million people fit these charactesistics. ${ }^{103}$ It should also be uoted that criteria for eligibility exclude those considered to be capable of entering the work force.

A Marxist evaluation of this policy effort would consider the devalued position of disabled persons in a capitalist system as being a consequence of the disabled being redundant to the requirements of capitalist, profit motivated, production process. Therefore this group is ignored except by humanistic agencies who in return for their services receive status and prestige (tax breaks, of more recent times). At the point when societal conditions warranted, a threat to social stability for example, policies and programs were enacted to satisfy militant groups. More recent developments in disabled policy reflect the input of the cappitalist class more directly in that conditions of eligibility are tied to participation in a reserve army of labour having the simultaneous consequence of social control. In this theoretical explanation of policy development and final product adequately accounts for the varying and often contradictory elements of disabled social policy.

The value premise contained within the Disabled Persons Act is essentually conservative in that nothing is altered in the way of past, present or future social relations, distribution of rights or resources. While the basic value and phalosophlyy of the policy was humanistic advocating some reformist effort, the actual 
operationalized version of the Act was heavily permeated by directives of social contsol. It may also be speculated, given the tining of this policy and the broad base of support with which the announcement was received, that a political objective related to the implementation of this act was not only to promote stability in the face of growing numbers and influence of disabled persons while achieving a broad base of election support.

The basic value composite of this policy the consequence can be predicted to effectivcly neutralize potential for achieving equality for disabled persons simultanecously satisfying advocacy groups, cultivating disabled dependency, and perpetuating the occurrence of social disability. Clearly contained within regulation directives is the goal of social control. The policy supports the notion of charity as a response to elevating disabled status when in fact the opposite effect is apparent, through reinforcing the negative, demeaning, public pes....... of the disabled projected by contemporary ideology.

The intended target group of this policy is, as is discussed in the opening chapter, is the very small percentage of disabled who require additional assistance in day to day routine activities. However the means to provide programming for this group was completely off base. Inclusion of all disabled persons regardless of extent of individual differentness would have supported a more comprehensive remedial strategy based on the premise of insuring full equality of condition as well as 
opportunity. Furthermore the potential target population is evidently limited by the dictates of the labour market according to regulated age restrictions. However, it is far more likely that persons severely disabled would be concentrated in the over 65 years of age category and thus the potential target poppulation of this policy would be relatively small.

The non-target group that are expected to benefit fiom this policy include: the families of recipients, employers of persons disabled on the job, advecates, various personal care organizations, medical professionals, and medical supply companies. Theoretically the entire society will be intluenced by the advancement of the charity ideology within the policy, and perpetuation of disabled myths.

The financial cost was minimal in the short run and especially low when considering the potential economic and political benefits to be harvested. Similarly, societal alteration was limited in the three previously defined domains of life and prevailing social structures were reinforced. Any qualitative benefit conferred to the target group was effectively depreciated by burealucratic and administrative imperatives, administrative procedures, and department developed regulations and directives.

In conclusion, while this policy appears to represent a qualitative departure from a pure capitalist, individualist philosophy tuward a more humanistic onientation, 
a closer examination reveals that the Disabled Persons Act contains the same deserving poor prerequisite as was evolved in early capitalist industrial revolution times. Submissions from advocacy groups guided by pure humanitarian considerations, sometimes even containing goals of equality, were largely ignored unless addressing such proposals would correspond to state covert intentions of social control, government legitimization, and/or societal stabilization. Consequently responsibility for the disabled remained at the private level, while state control into this sphere could be exercised at minimal cost. This policy only altered existing status relations by further ingraining and protecting such arrangements. The policy produced a situation of disempowerment and forced dependency for the severely disabled target group while completely ignoring the majority of disabled persons. The charity relationship entailed within the policy widened the gap between disabled and non-disabled by elevating the status of the givers and consequently diminishing the standing of the recipients. The rights of the disabled may hav'; been advanced through the allocation of financial resources, although the real change may be regressive in that such funds were actually transferred on the condition that the right (1) self determination and privacy be surrendered. Finally in terms of ideological change, this policy potentially could result in a mass societal alteration whereby a sense of social responsibility is fostered in opposition to the contemporary individualistic, survival of the strongest mentality. Unfortunately and potential progress in this respect is limited by the promotion of a devaluing disabled ideology an ising from clcments of paternalism and charity. 


\section{THE VOCATIONAL, REIIABILIIIATION FOR DISABI LLD PROGRAM ACI (1961)}

The introduction of The Vocational Rehabilitation for the Disabled Act (Bill C-84) on January 25, 1961, marked a significant change in governmem : w)licy toward disabled persons and as such is a major step in evolution of social policy and ideology with respect to disabled people. The VRIDP Act reflected a variety of socictal intluences and environmental pressures culminating in a promising humanistic effort corrupted by political and economic vested interests. The VRDP Ac! received royal assent on June lst after a fair amount of debate and charges again by opposition parties of government political grandstanding without any real action. To this day it renaains the object of debate between opposing forces in the struggle for change. ${ }^{\text {lot }}$ While the policy appears to represent the official codification of meaningful ideological shift from charity provision to rehabilitative training, closer scrutiny reveals that the policy represents no substantial improvement over the pessitions which were already in place since $19533^{105}$

The purely humanistic objectives of the policy had been called for as easly as 1943 in an article titled "Vocational Relabilitation During and After the War". One consequence of the VRDP was to enhance the position and power of medical professionals while more deeply engraining the work ethic and other labour manket related ideologies in the public consciousness. ${ }^{100}$ The real purpesse may have been to respond to shifts in the labour market induced by demographic changes, ${ }^{107}$ and as 
a means to perpetuate political power and stability in the face of a pending election and shufts in the cconomy. At this time a large percentage of the population were cintering their teen-age years and would soon be joining the work force. Thus this policy can be considered to have arisen from the unrelated eflects of political intention, state function, prevailing philosophy, negative disabled ideology and capitalist demand. ${ }^{106}$ Regardless of the societal alteration and actual intended maligned objective, the publicly promoted policy had only a superficial impact upon the target area, and was characterized by elements of the work ethir, and an individual medical focus to the exclusion of societal restructuring. As a M.P. in the house of Commons stated in support of the policy;

\begin{abstract}
"if we accept our full responsibility in this respect, along with the Provincial and Municipal governments, voluntary organizations, and all of those of us who profess to be christian citizens in Canada we will find that fruits of this legislation will be happiness, through purpose and independence, for those who do not now enjoy them."109
\end{abstract}

The contents of the VRDP policy provided authorization for the Dominion to enter into contracts for up to a six year period with the provinces for the provision of rehabilitation services to disabled persons not covered under other programs on a 50-50 cost shared basis. This scheme granted the Provinces implementation and planning responsibilities while the Federal government retained administrative control. It also provided for the establishment of a rehabilitation services 
coordinating body, a mechanism for conducting research, and most importantly it gave life to the National Advisory Council on Rehabilitation :is Disabled Persons. A majority of the Act's clauses make reference to this newly created body, which was to serve a potential social control function by gahering information absut disibled persons and advising state policy.

The Federal goal to gai. control over provincial areas of jurisdiction is inherent within the purpose of cost sharable arrangements between the two levels of government (section 2). This mechanism of control had been used previously and groven effective for directing individual states by the American example of Vocational Rehabilitation legislation known as the Fess-Keyon Act (1920-43). ${ }^{110}$ It was primarily for the reason that Quebec opted net to be a partner in this legislation, since they did not desire Federal infringement upon their dom:- of living. The financial aspect of this mechanism has also been criticized on the grourds of doing nothing to diminish regional economic disparities."

The restrictive definition of disability determining eligible persons in the preamble was expected to include only between ..\% and $2 \%$ of the pof ulation, thus demonstrating the limited applicability of this program." The narrow and exclusive definition of disability was a majci poii $t$ of criticism upon third reauing when one opposition M.P. noted that a large percentage of disabled, known as alcohol and drug dependant, would be left out. ${ }^{113}$ According to currently accepted detinitions of 
disability $15 \%$ of the population are considered eligible. Only 300,000 perople were targeted under the origina! intent.

By liar the most evidence of the Act's benetit for any segment of the fonnulation can be found in sections 4d, 7, and 8, which provides incentive and support for medical profession expansion. Michaci Starr noted during the policies lirst Ieading, March 14, 1961, that the primary goal of the policy was to benefit profiessionals.

"I a'n glad to say that with the stimulus of federal government assistance in this field medical and rehabilitation facilities are being improved and a large supply of appropriately trainced medical personnel is now available." 114

Consistent with this policy it would be necessary to greatly expand medical facilities for disabled persons. The actual number of related medical staff jumned locally in the year after the policies ammouncement from 70 to $140 .^{115} \mathrm{~A}$ corresponding increase in medical profession power and influence seems likely.

The conditions of this policy's derivation and :- eial pressure influencing its crolution were many and varied. Most can be directly attributed to and are related (1) shifts in the labour market, while the underlying premise is fuelled by the intentions of well meaning advocates and social teformers. Persons having direct 
intluence into the policy outcome included the National Advisony Commuttec (alleadly in existence, with a number of government tepresentatives), volumtany agencies, labour, management, the medical profession, and the Universities.

A major incentive for the development of this legislatton was the tixe in popularity of the concept of relabilitation. The rise of the relabbilitaton moventent can be credited in the early stages to charity organizations, the development of orthopaedic surgery, and the worker's compensation success. The National Conference on the Rehabilitation of the Disabled, sponsoned fointly between government organizations and the medical profession, in 'Toronto 1951, was a major motivating event and represented a concerted elfort to establish the rehabilitation movement in (anada. ${ }^{16}$ Prior to this state tesponse ad-hoce programs had existed to varying deguees for veterans, disabled employees, the blind, and persons sulfering from tuberculosis. Operationalization procedues up until 1961 followed the American methodology of authorizing ad-hoc grant in aid funding heavily aclying upon the voluntary secter. ${ }^{117}$ It should be cautioned however that the concept of rehabilitation at this point in time denoted medical treatment only, and programes of the 1950's did not extend significantly in scope beyond this definition. The Canadian approach was similar but lagged five years behind the British model. Accosdeng to contemporary philosophy following the example set in Lingland... 
"Rehabilitation is defined in the United Kingdom as that part of medical and surgical treatment which is concerned with the full tecovery of physical and mental functions that have been damaged by illness or injury, and with the restoration of the patient to his former sphere of usefulness, or with his preparation for a new vocation better suited to his reduced capacity... relabilitation is primarily a medical process". ${ }^{118}$

Inherent in this philosophy is a depiction of the concept of disability as being abmomal and undesirable while inaintaining an individual focus and ignoring covironmental factors. The implications of this ideological restriction in the medical model paradigm have been discussed in chapter one. International pressure for introducing the rehabilitation approach to disabled policy came from examples set by the much more socially progressive programs operating through the European Common Masket as were presented during the International Labour Conference in Geneva by the United Nations Education, Scientific, and Cultural Organization. At this :mic many European countries were implementing programs designed to get persons with disabilities into the labour force. ${ }^{119}$

The devalued, abnormal perspective of the disabled found in the U.K. model of rehabilitation was also evident in the minds of contemporary politicians and other state Iepresentatives. The Minister of Labour, who was responsible for the VRDP Adt, stated during the committee stage that the intent of this action was to "enable many seriously disabled Canadians to rise above their handicaps" and "to stand on (their) own feet". ${ }^{120}$ This statement not only bears a negative bias in conceptualizing 
disability, but alsw promotes the concept of individual responsibility and the work cthic. One opposition M.P. participating in the debate referred to the disabled as "aflicted with a disease". 121

It is probable that the policy was tied to fluctuatons and recpuicuments of the labour market. For example, the number of immigrants dropped dianatically in 1961, conseguently creating a corresponding void in persons available to enter the labour force. Also, given the entrance of the post war baby boom gencration into the labour force in the 60's, the VRDP ploject may have served as a pilet project for testing the usefulness of the responase for application to nom-disabled populations. Future stability and decreased burden on the welfare system maty have becin at peripheral motive ior engaging VRDP programming, as was cluded to in a study by a Civilian Rehabilitation Branch, of the Department of 1 abour. ${ }^{122}$ An abundance of evidence does exist that economic benetit was a key motivation leadung in the introduction of this policy. One M.P. in the llouse of Commons moled that an estimated $97 \%$ of disabled persons could be chabilitated and thus buden upon the public could be decreased proportionately. ${ }^{123}$ George V. Haythone, Deputy Minister of the Department of Labour stated that the goal of this initiative w.as to get people off public assistance and contributing to the country's economy. Ian (amplocll, National Coordinator of Civilian Research, appealed to the publics sense of the obvious by using an example of 7,975 disabled who cost $5,40(0,0(0)$ a year $(0)$ suppost, but after vocational rehabilitation were making a total of $14,4(3), 000)$ per year. ${ }^{124}$ 
firom the business community came examples as early as 1950 asserting that in Montreal alone an estimated $674,(6 \times)$ disabled could be rehabilitated and put to work saving the country 86 million dollars annually. ${ }^{125}$ Similar articles could be found in the linancial Post in 1961, one such composition claimed tremendous rehabilitation suceess for 29,000 disabled persons in Newfoundland. ${ }^{20}$

Regardless of the economic benefit to be derived from enactment of this policy the opposition parties and many community groups publicized a major flaw in the Bill largely related to its misplaced objectives. Training and rehabilitation of the disabled does not automatically result in successful labour market acceptance if opportunities for employment simply do not exist. At the heart of this well founded caiticism was the misguided, individual policy focus, and the systematic exclusion of alternatives aimed at restructuring the environment. Solutions, in the reformist nadition, focused upon the individual. Mr. Carter, for example, suggested the inclusion of an individually targeted aftirmative action component; "I hope the federal government will develop a policy giving preference to disabled persons". He suggested that restrictions for disabled persons were "inherent" in the environment. ${ }^{127}$ Although his idea was in the progressive direction it fell short of meaningful societal Icconstruction, yet other critics seemed to advocate a stronger economy as the solution and accordingly the invisible hand of tie market system would take care of the problem. Regardless of the alternatives proposed it was admitted toward the erd of the Third reading stage the policy did not authorize intervention at the 
environmental level that would subsequently not result in necessary structural change. The social intervention focus was however actively promoted at this time by organizations like the Civilian Rehabilitation branch of the Department of Iabour and the Canadian Paraplegic Association. In one article the crucial element of disability is promoted as being social and ecomomic prejudices. ${ }^{128}$ fl furfher submits that a negatively biased ideology has undermined disabled potential in the minds of the public at considerable social cost to both the disabled individual and the entire nation. ${ }^{12 y}$

Currently state response is still sech as being inadequate with respect to compensation and job protection programs, denounced as being misguided by more militant groups like the Manitoba Leagueof the Physically Disabled, (')alition of Plovincial Organizations of the Handicapped, and the British Columbia (Aalition of the Disabled. Among their concerns about VRIPP legislation are; the compilexity of the agreement, agency mediation and lack of individuat self detemination, lack of public appeal mechanisms, age categorization, sheltered workshops, proglanms paying less than minimum wage, welfare department supervision, lack of consumes input opportunity, means testing, lack of service continuity after employment is obtained, lack of universality, arbitrary definition of need, and services given on condition of gainful employment. ${ }^{130}$ Many of these concerns reflect the tinal change in ideology need to achieve total equality and are in line with the social model perspecting secking absolute rights allocation. 
Social legislation fur the disabled represents a response to societal instability. Statc responses to the needs of disabled citizens may take a number of forms but mevel anthorize the significant reforms necessary to produce a situation of lotal equality. Instead actions made reference to by government policy usually are characteristic of the state's hidden agenda and various elements are evidence of the stunggle by opposing forces. Depictions of this occurrence have been presented though examples of the War Veteran's Allowance Act, having largely a political purpose, The Disabled Person's Act and The Blind Person's Act, which were motivited by global war and an economic depression thus serving a socictal stabilization function, and finally the VRDP Act, although first proposed almost two decardes earlier, arose when the requirements of the changing labour force and ixpulation demographics warranted therefore having political, economic and societal stabilization objectives. The process followed by state policy development may be simplistically depicted in the following schematic representation, according to the tindings of the previous policy analysis. The "Social Forces" and "Prevailing Ideology" segnlint was depicted eatlier on page 38 in the diagrams representing influences on the policy making process. 
(lime, place and spacc)

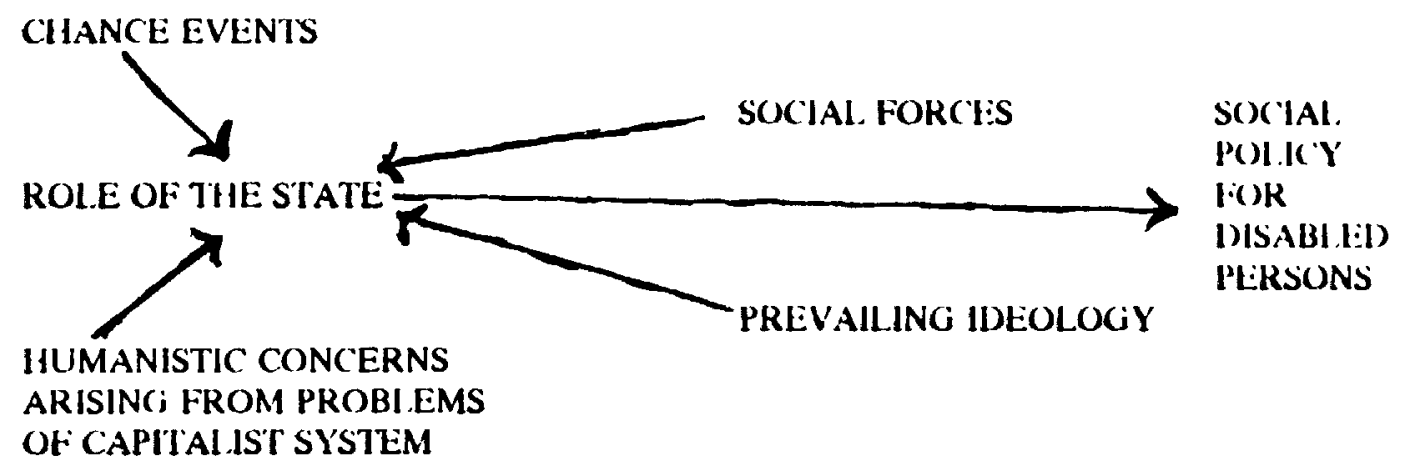

It is ironic that traditional approaches utilized by the capitalist statc for resolving the social problents, actually arising from the capitalist system type of organization, tend to perpetuate rather than irradiale the occurrente. Ifowever recognition of the dynamies and conditions of change can result in the development of strategies to counter this self-defeating cycle of state intervention. The next chapter will provide a case study illustration of how mistaken Federal policies are transformed directly into ineffective and restrictive programs at the Provincial implementation phase. The subsequent chapter will examine the most recent development in disabled social policy according to the critical model proposed fiesc aimed at the development of alternative policy and strattegy. 


\section{ENDNO'ILS}

61. 1)ISABI.101) PERSONS IN CANADA, Ottawa, Health and Welfare 1980, Page $11 \%$.

62. Page 200)-205, IHE M/EI FARE STATE IN C.ANADA.

63. "Health and Activity Limitation Survey", Statistics Canada, Ottawa, 1988.

64. "Worker with Disability Makes Fine Employee", Iabour Gazette, May 8, 1943

6.5. Denuis Guest, THE EMERGENCE OF SOCIAI, SECURITY IN CANAIDA, Vancouver, University of British Colombia Press, 1982.

66. David A. Wolfe, "The Rise and Denise of the Keynesian Era", MODERN (ANADA 1930-198(1)'s Toronto, M'Lelland and Stewart, 1984.

67. Dennis Guest, THE EMERGENCE OF SOCIAI. SECURITY IN CANADA, Vancouver, University of British Colombia Press, 1982.

68. Irving (joffman, SOME FISCAL. ASPECTS OF PUBI.IC. WELFARE IN (ANADA, Toronto, Canadian Tax Foundation, 1965, Unpublished.

69. "The Statement of a Permanent Disabled North West Volunteer, 1889", MCR lic:18 C:15:(17488, Carleton University Library, Ottawa

70. Dennis Guest, THE EMERGENCE OF SOCIAI. SECURITY IN CANADA, Vancouvel, University of British Colombia Press, 1982.

71. House of Commons Debates, Ottawa 1931.

72. The (ilobe Newspaiper, Toronto, May 17, 1929.

73. Itouse of Commons Debates, Ottawa, May 24, 1930.

74. House of Commons Debates, March 11, 1930.

75. Ibid.

70. Auditor General Report, Dominion, 1951.

77. Second reading of the Act, Iouse of Commons Debates, Ottawa. 
78. Alterations in policy direction correlated highly with fluctuations in GNP and other significant world events.

79. "Old Age Pensions and Pensions for Blind Persons in Canadi", LAB()I/R GAZETTE, Sept. 30, 1947.

80. C.N.I.B. Grants increased from 18,(60) to $45,(00)$ dollars in 1951.

81. House of Commons Debates, June 21, 1951.

82. "Old age Pensions and Pensions for the Blind in Canada", Lalbour Ciazelle, September 30, 1942.

83. House of Commons Debates, June 15, 1951.

84. Chapter 38, Revised Statutes of Canada, 1984.

85. THE I.ABOUR GAZETTE, Dec. 1947.

86. Page 23, TRADES AND I.ABOUR CONGRESS, November, 1954.

87. Page 30, FINANCIAI. POST, Feb 11, 1956.

88. Jeffrey Galper, THE POIITICS ()F SOCIAI SLRVICISS New Jersey, Picntice Iall, 1975.

89. (iL. ()BE and MAll, newspaner, Thursday, June 24, 1954

90. Consistent with Marxist theory on the role of the stale, Alexander Himellarbo, and James C. Richardson, Sociology for Camadians, Toronto, M'Graw-Hill Rycrson, 1982, P. ige 222-224.

91. Revised Statutes of Canada, 1981.

92. House of Commons Debates, June 1954.

93. IABOUR GAZETTE, "Recent Regulations, Federal and Provincial", February, 1955, Page 104.

94. Globe and Mail and Star, newspapers in Toronto, between 1953 and 1955 reveal the existence of these trends peaking around 1954.

95. "Report of the Canadian Paraplegic Association" INI)(ISIRIAL. (ANADA, Nov. 1, 1948, Page 182. 
96. Sept. Oth to 14th, "Ist Conference of the International Society for the Weltare of Cripples", Stockloim Sweden.

97. (ANADIAN WEIEARE, March 15, 1954, Page 41.

98. "More Than a Crutch for the Cripple", CANADIAN BUSINESS, October 1951, Page 40.

w. Preamble from the DISABI.ED PERSONS ACT.

1(x). Iirst Reading, House of Commons Debates, May 24, 1954.

101. "Recent Regulations, Federal and Provincial", LABOIYK GAZETTE, Feb. 1955, Page 184 .

102. "Across Canada", C.ANADIAN WEi.FARE, Feb. 1, 1954, Page 13.

103. Health and Activity Lirintation Survey, statistics Canada, Ottawa, 1988.

104. VRDP gricicism from Cualition of Provincial Organizations of the Handicapped, 1981

105. Unlegislated programs similar to VRDP were already in place at this time.

166. (ANADIAN JOURNAI. OF ECONOMICS AND POI.ITICS, May 1943, Page 164.

107. "Immigration into Canada Decreased in 1961", THE L.ABOUR GAZETTE, April 1962, also Statistics Canada reported the increase in reserve labour force due to maturation of baby boomers and thus a decrease in immigration rates.

108. Page 1/2, "Rehabilitation of Disabled Persons", CANADIAN WEI.FARE, July-August, 1963.

109. Mr. Herridge, House of Commons Debates, April 19, :961.

110. IIII: RIIIABILITATION OF DISABIED PERSONS (Background Data for the National Conference on Rehabilitation, Toronto 1951.

111. Bricf prepared by the B.C. Coalition of the Disabled, October 1987.

112. Huse of Commons Debates, March 14, 1961.

113. Judy A. LaMarsh, House of Commons Debates, May 1, 1961. 
114. House of Commons Debates, March 14, 1961.

115. "Rehabilitation of Disabled Persons", (ANADIAN Vte.FARL: July-Augaust, 1963.

116. "First ineeting, National Advisory Council on the Relabilitation of Disabled Persons", I.ABOUR GAZETTE, June 1962, Page 6(12.

117. T.C. Foster, CANADIAN JOURNAL OH OCCUPATIONAL TIII:RAPY (Xi., 1939, Page 64.

118. THE REHABILITATION OF DISABI.EI) PERSONS, Toronto 1951, Pagi 3.

119. DISABII ITY, SITUATION, SIRATE(IIES, ANI) P(OI ICIES, Intcrnational, Labour Conference, Geneva, June 1, 1955.

120. Michael Starr, House of Commons Debates, March 14, 1961.

121. Mr. Sevigny, House of Commons Debates, April 19, 1961.

122. THE LABOUR GAZETYE June 1962, Page 6(13.

123. Mr. Carter, House of Commons Debates, March 14, 1961.

124. LABOUR GAZEITE, June 1962, Pagc 6012.

125. "More than a Crutch for the Crippled", CANADIAN BISSINI:SS, (). 195 !.

126. "Council Improves Lot of 29,000" EINANCIAL. POST, June 26, 1901, Page 52.

127. Mr. Sevigny and Mr. Pitman, House of Commons Debaltes, April 19, 1961, Page 3809.

128. "Vocational Rehabilitation Before and After the War", (ANADIAN J()URNAL. OF ECONOMICS AND POI.ITICS, May 194?, Page 164.

131. "On behalf of the Disabled", CANADIAN WEI.FARE, Vol 38, April, 1962, Page 64.

132. Info-COPOH newsletter, Vol. 6, No. 2, Feb. 29, 1988, and Ralph Kuropatwa, and P.J. Byrne, "Final Report on the First Assignment of Canada Assistance Plan/Vocational ehabilitation of Disabled Persons Act Federal-Provincial Revicw Committee", December 1981, Unpublished. 
CIIAPITLR IOUR: THE COMMUNITY SERVICES TO DISABL ED PROGRAM; A CASL: I:XAMPIESOF MISDIRECTED PROGRAMMING RESULTING FROM MISCiUIDI:D P()L.JCY

The following case study is an example to illustrate ineffective programming arising from mistaken policy and ideology. The program described in this chapter is the Community Services to the Disabled program (CSD) administered by the I'rovince of New Brunswick through the Department of Health and Community Services and other non-governmental community based organizations. All of the information about this program was gained through first hand involvement. The first association was with the central planning office of the Department of Health and Community Services and chiefly involved the development and administration of CSD programuning. Other experience with this program was gained while working at a regional office of the Department of Health and Community Services where this program among others, were implemented.

I will argue here that the program could not have resolved the problems contionting disabled persons because of a traditionally biased perspective on the needs of disabled persons acld by program development and administering agents. Lach level of operation was faced by different realities, having different goals, but a shared misguided ideology. ${ }^{131}$

Before 1981 a service gap existed in the province of New Brunswick for disabled individuals between the ages of 19 and 64 . Winile people 18 years old and 
under were served by the Community Based Services for Special Needs Childen program (CBSSNC), persons 65 years old and over were aided by the Communily Based Services to Seniors program (CBSS). The age criteria and the resultiin: vacuun correspond directly to the age eligibility for the labour market thus assuming If.at those who can enter the labour market can take care of themselves. Persins not fitting into eitter of these two categories were given aid only on an ad-hoc basis with no siandard definition of disability, need, or level of service. The apparent n. ed of this group of disabled persons was growing rapic!ly in the public's conscions sncss. The separate government policy of deinstitutionalization whereby hundreds of formerly institutionalized residents were discharged into the community and left to fend for themselves made the need for some sort of government response apparent. This problematic condition, although always obvious to disabled persons between the age's of 19 and 64, was first publicly tabled by disabled advocacy groups like the ('anadian Paraplegic Associatios. (CPA), the New Brunswick Ins.itute for Community Living (NBICL), and the Canadian National Institute for the Blind (CNIB). Their desires were expressed more in the form of requests rather than demands and based on a cooperative rather than confrontative approach. Through the newly appointed Premiers Council on the Stai!s of the Disabled the government proposed a liberalised response in the forin of $\mathrm{CSD}$ programming. The Premiers Council itself had previously been introduced at a time of growing militancy amosng c'isabied persons, but given litte more power than the ability convej the needs of disabled persons to the government and thus served to institutionalize contlict. 

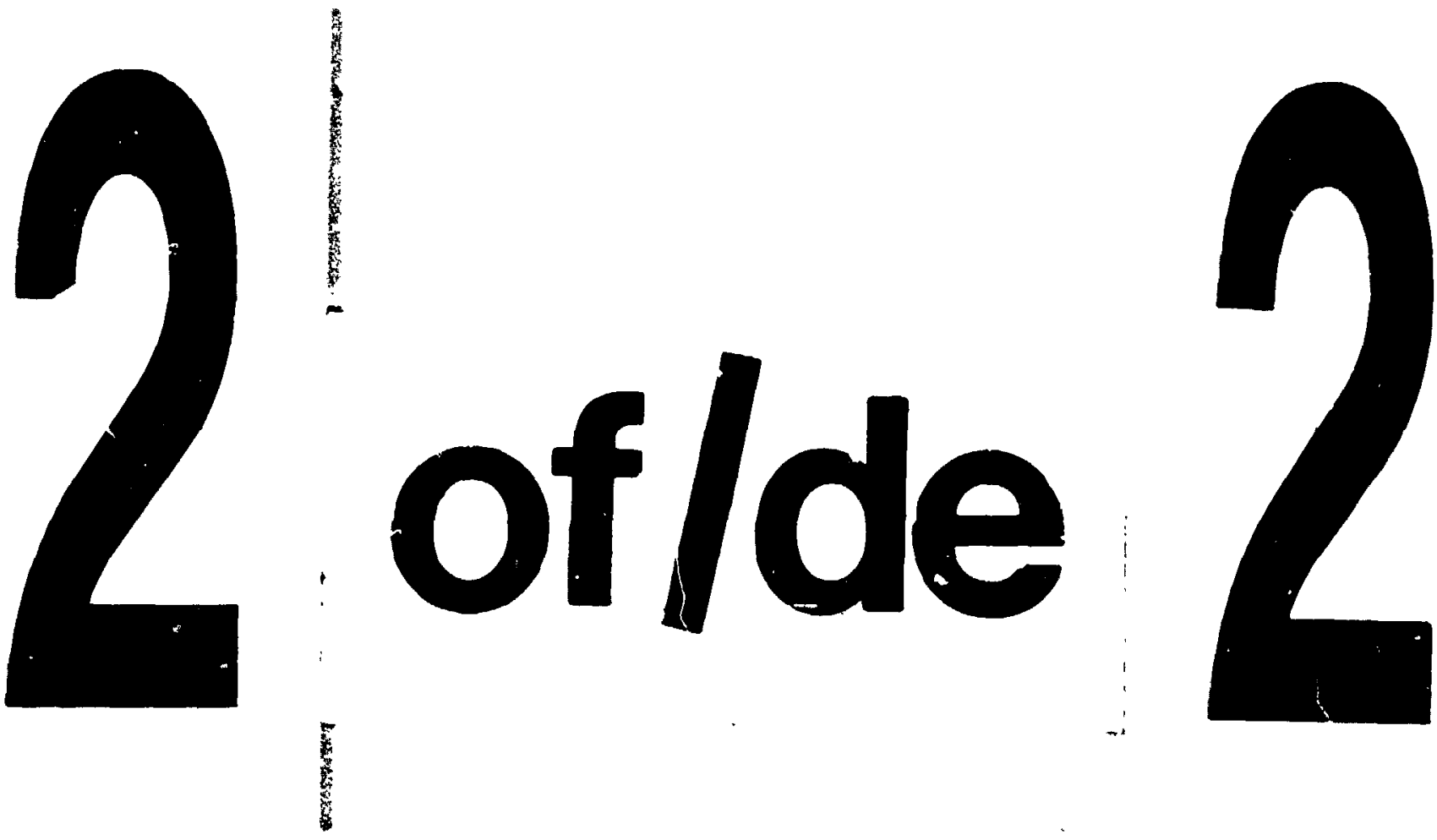

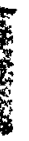

PM-1 31/2" $\times 4 "$ PHOTOGRAPHIC MICROCOPY TARGET NBS 1010a ANSI/ISO *2 EQUIVALENT

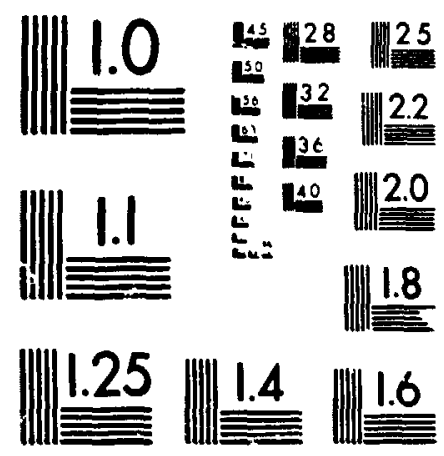


The rationale as is stated in the general policy authorizing the program, is that disabled persons may have greater needs than other members of society and a reduced or totally diminished capacity to meet those needs. In these cases such persons have the right to have these needs met through government programming. Programming should enhance the life circumstances of disabled persons and thus provide a greater number of npportunities for societal participation. These vaguely stated principles, howcver could never result in more then an extension of the existing social order, prevailing conservative philosophy and structure of socielal relations, since allocation of resources remained minimal.

Activities sponsored under the CSD program included: information and referral, assessment and screening, case management and coordination, respite care and family support, and the potential to develoin a better community based service system in the Province. Services were intended to encompass everything required to meet basis: needs, elevate living standards to the National average, and increase the degree of socictal participation. Under this program authorized agencies would be responsible for providing counselling, education, information, fulfilling mater ial needs, and supplying technical devices. All services were designed to enhance the persons life skills and vocational ability. However regardless of how well these worthwhile goals and objectives have been articulated in the program design, it is doomed to failure since financial resources were not allocated and important issues like regional economic disparities and institution of a more progressive ideology are not addressed. 
Specified services to be included under CSD programming included; information to the general public, prevention of causation of disability, identification of clients and problems, assessment of functioning and need levels, family support services, funding and/or provision of assyriology devices and equipment, residential living enhancement, vocational training and employment, transportation services, income security, protective legal services, leisure and recreational information, and advanced education coordination. Objectives to be achieved through the provision of these services included: filling the service vacuum for adults who were disabled, cnhancing life and opportunities for adults with disabilities, providing an alternative to institutionalization, providing a minimally acceptable level of standardized and coordinated services to adults with disabilities, and finally, to cultivate and develop the existence and usage of non-government community based services. The pragmatic application of these services, restrictive budgets resulted in services falling far short of the objectives listed above and by no means enabled disabled' persons to achieve objectives of equality. The type of response offered in the CSD program conformed to the prevailing belief that disabled persons fit into the deserving poor calcgory and as such resources were distributed under the program not as a legitimate right toward achieving equality but rather as a charitable exercise.

The first step in the implementation process was a skeleton pilot project deve'oped in two regions (Fredericton and Cambellton) to test the feasibility of chacting a province wide program. Although no formal evaluation was conducted to 
determine the effectiveness in providing for the needs of disabled persons, the program was expanded to all other regions in the following years under the same skeleton directives. Oniy minimal budgets were provided to each region while level of service and determination of need were still being assessed on an individual basis and subject to the bias of the case worker. Lack of universal standards coupled with the prevailing negative ideology of many workers resulted in situations where two persons with the same needs in two different areas of the province received remarkahly different amounts of service. The province wide situation diflered little more than that which was the norm before its implementation except now the government appeared to be addressing public concerns.

It is suggested here that the main objective behind introducing the (SI) program was to placate groups secking resolution of the problem without expending an unneessarily large amount of money and maybe even saving some in the process. The program fit well within the public's conception of a charitable response to the disabled, did not threaten the prevailing system of social relations, and provided a good public relations exercise for the government. This gesture to the community of disabled persons was useful only to the broader electorate as a means to white wash the recent decision to deinstitutionalize many ploysically and mentally disabled persons. Positive public relations activities were warranted at this time because the Richard Hattield government had recently weathered a number of scandals and feared losing the next election. One major issue relating to the program's approval 
was that it was needed and would benefit a sizable population at a lower cost then the current method.

At the program development stage it was not questioned that disabled adults tetween the ages of 19 and 65 deserved services presently not available. The focus of concern rested upon parameters of service promoted through strictly enforced, narrow eligibility criteria. This practise of misplaced motives subliming the real issue is not uncommon in social program design and does have a major impact upon the achievement of stated objectives. The program was developed and implemented alnost completely on the basis of cost effectiveness and political mileage. Based upon the absence of motives like enhancement of chances to achieve equality for persons with disabilities and the presence of economic, and political motives it can be predicted that this program is not likely to significantly advance the status of persons with disabilities in the province of New Brunswick.

At the time of program developinent certain assumptions were made about the implementation process. Firstly, eentralized programming and decentralized implementation is bound to result in backlash from regional offices because of disparatc local needs. Differences in perspective between progran designers and implementors can also be predicted. A major goal of central office planning sor the Department of llealth and Community Services was to maintain control over the program by reducing regional office discretionary power and restricting budgets. 
Thus the dilemma arose in that the program must be kept simple so as to ensure a trouble free implementation process yet it's directives must also be compreheasive enough to control the action of workers at the client service level.

A second major assumption concerns the disparity between north and south regions of the province in terms of resources available to implement the program. The application of universally applied standards would not necessarily mean equitable levels of service in both the top and bottom of the province. Many other peculiarities that would impinge upon the implementation process and ahe entire programs suceess were also not addressed in the program development stage. For example, it was not considered that many disabled persons lived in rural areas were community based services had no or limited capacity to provide service. Privately run community bascil services were not uniformly stationed across the province, and were largely concentrated around the Fredericton region because it was the funding source. I ines of communication between structures of govermment and the service implementors were bound to be poor because of the hierarchical, bureaucratic structure and the political need to control information. Competition and duplication in servicing was bound to occur, resulting in confusion and alicnation, withor a complete assessment and reorganization of existing service providers and programs.

The effects of separate but related policies like the transference of mally services from the department of Itealth and Community Services program 
administering agent to the Department of Income Assistance, had not been considered. Also prior to this period the Department of Social Services was joined to the Health Department, thus creating a great deal of confusion and in fighting. formal contract for services program standards were then evolving as a major new policy. As was mentioned earlier, problems with unequal service depending upon the exitance of service provides in each area arose when the C.S.D. program was provided through contract for services provisions.

Finally, a very important reality was not considered. A large number of persons from different backgrounds, having different tasks, goals and focuses, would be involved and potentially affected by the program in some way. In this final important aspect of policy implementation the different domains of reality should be considered when seeking to analyze a policy. These problematic aspects were not addressed in the original design of the program and thus the program can be predicted to fail in terms of service continuity. According to this analysis, not much change could be anticipated from the situation that previously existed. ${ }^{132}$

The CSD program was dependent upon inadequate regional budgets, as can be expected in an economically depressed region of the country, thus reducing the likelihood that it could effectively meet the needs of the target population. Existing private and public community based service agencies lacked the capacity to accomplish the task under such strick measures of contrel and minimal resource 
allocation. Restrictive budgets and a prevailing conservative philosophy made major innovation impossible and social change was mot likely to ensue from this progtann. The occurrence of this situation is easily predictable when the four puimary domains of persons effected by the program are considered.

In the decision making domain, occupjed chiclly by politicians and sconion bureaucrats, goals of power attainment and maintenance are necessitatted by a liberal democratic structure. Political objectives in kague with a dominant conservative ideology serve to stabilize the enviromment, maintain the prevailing status-quo and social order. It is not likely that a potential large scale social change would be in voluntary introduced under these conditions. At the central offiec, administration and support domain, the function is to design, implement, monitor and adjust policy. However all of these tasks are subject to limitations promoted by the decision making domain. Therefore even worthwhile goals of equality that may be promosted at this level soon come in conflict with conservative ideology-and objectives of societal stabilization through status-quo maintenance. In the operatomal domain, inhabited by regional office workers and community service employees, the respective functions are control and implementation. Both are policy interpreters within the guidelines set out by the top two domains and their own perspectives about disability. Finally at the impact domain, those who are effected by the policy can be tound. Two distinctive groups si, uld be considered here. lïrst the powerless target group who have absolutely no input into any of the other domains can be expected to receive 
very litlle benctil from this program beyond that wlach had previously existed. The wther group), in stark contrast, are members of the political party in power and senior buscaucrats who stand to gain significant benefit from the policy's implementation in the way of pessitive public relations, justifying their position, job, and status.

While the principle of the CSD program may have contained enormous postential tor producing elevated status for disabled persons, such was not realized because it was authorized by a political system having contradictory motives, introduced in an atmosphere dominated by conservative ideology, and corrupted by the structure of the designing and implementing system. This case study illustrates the impact of ideology upon social policy, and the resulting impact upon the material condilions and statuses of various groups in the social structure. This example is not expected to difler greatly when analyzed for effectiveness from any other social program having similar liberal reformist stated objectives and introduced within a capilalist type coconomic system. 


\section{ENI) N(TIIS}

131. Donald E. Chambers, Social Policy and Socia! Programs; A Mecthod fon lluc Practical Public Pollicy Analyst, New York, M“Millan, 1980.

132. Jeffrey I. Pressman and Aaron Wildausky, Implementationi The ()arcland Project, Los Angeles, University of Califun nia Press, 1984. 
CIIAPIIER IIVI:: TIHE CONIITIONS OF SOCIAI. CHANGL AND THE ROI.E .)I 'THII: DISABILE CONSIMLIR MOVEMLNT' IN ACHILVING CIVII. RICili'IS

While it is true that chance events and the existence of a certain set of social comditions are necessary ingredients to the development of social change, the role played in this process by individuals and groups should not he over looked. When considering the occurrence of social change a combination of interdependent elements must be explored to provide a more valid explanation. This chapter will discuss the role played by vanious groups of disabled persons and advocates, in relation to the existence of certain societal occurrences, resulting in public recognition that disability is grounds for claiming discrimination under the authority vested in the Canadian Constitution, Charter of Rights and Freedoms. An event such as entenchment of rights for disabled persons in the highest statute in the country is listenically signiticant in the evolution of social policy for disabled persons since the circumslances surrounding it's formulation represent a large shift in ideology from the chanty based ethic to recognituon of civil rights.

Altcration of human rights legislation to include disability as grounds for claiming discrimination is considered a signiticant event because it marked the sucecssful climax of actions sponsored largely by the growing consumer and ights activist movement toward achieving full economic and social equality. According to the perspective advanced in chapter iwo, I would submit that by examining the crolution of disiabled social policy, and especially the recent Charter of Rights 
amendment, a model for social change may be advanced, relevant to all oppressed mimority groups.

It is suggested here that if the same conditions of social, political and economic inequality confronted the general pepulation as is the situation of everyday life fur disabled pes... sns, society would expericilec a great deal of unrest amomb it's citizens and the state would be faced with a potential violent revolution. Jolun Clank notes that ideology, traditions, customs, various forms of marginalication and discrimination may suffice as a means to bar disabled persons from develuping a revolutionary consciousness or engaging in calculated radical activity. ${ }^{133}$ Padslu Filcte, on the other hand, notes that even the most restrictive forms of state sponsored oppression cannot inevitably subdue repressed persons. ${ }^{\text {IH }}$ In fact, disabled persons have been historically deterred from activism bui more recently have achicved significant gains toward goals of equality. As was noted in chapter threc the unintended consequence of many social policies, as a function of the underlying charity ethic, has been to instill a sense of passivity among disabled persons. Thus passivity began to diminish in the latter half of the 1970's when many disabled persons opted for activism and subsequently the formation of militant colleclive organizations having social change as an objective. Although these groups call mot be considered revolutionary social institutions they are potemtially at the vanguand of broad social change. Most of these organizations are premised upon and advocale 
a new idechlogy related to disabled persons. In response to the traditional charity philosophy, they advocated for equal rights and opportunities in place of hand-outs.

Henry Enns, a noted disabled activist and one of the founding members of Disabled Persons International, has predicted that 1980)-81 will be considered by fulure historians as the turning point in the oppression of disabled persons. ${ }^{135}$ Internationally this time was declared by the United Nations as the Year of the Disabled, thus publicizing that all persons with disabilities were facing problematic situations. ${ }^{130}$ The Canadian state responded with policy changes toward the disabled, premised under suggestions advocated by disabled persons themselves. In 1983 disability was included as grounds for claiming discrimination in the Canadian Charter of Rights and Freedoms. For the purpose of understanding social change, the period immediately prion to this constitutional amendment should be scrutinized. Par:y Ifolmes, a disabled consultant to the Canadian Labour Congress, described the preliminary period as a time of great unification and mititancy among the Disabled' community. The rise of previously uncharacteristic solidarity followed a very distinctive path over time whereby increments correspond roughly to changes in state Iesponse to the perceived needs of the disabled. The following chart schematically depiets the hisiorical development of organizations for the disabled and resulting state respouse. 


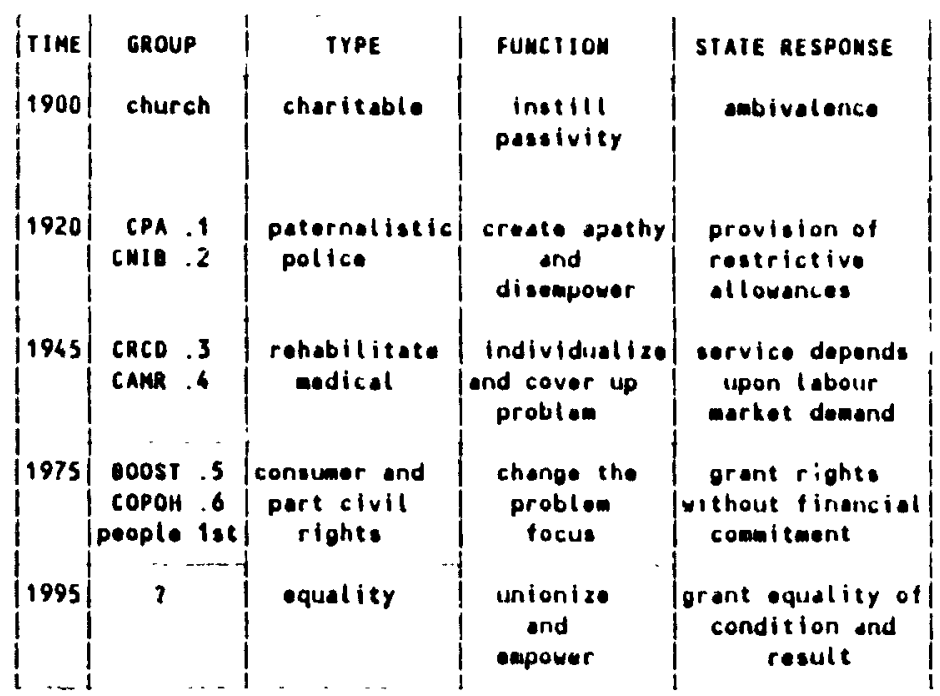

1. Canadian Paraplegic Association

2. Canadian National Institule for the Blind

3. Canadian Rehabilitation Council for the Disabled

4. Canadian Association for the mentally Retarded

5. Blind Organization of Ontario for Self-Help Tactics

6. Coalition of Provincial Organizations for the Handicapped

The conditions producing the most recent stage in the evolutionary history included valious significant social developments. Firstly, the human rights movement brought about major revisions to legislative authority resulting in a ideological shift from the provision of eharity to application of equal rights to access socictal opportunities. Secondly but equally important was the many trends including previously unthoug!nt of applications for newly developed technology, the gradual aging of society, an increase in the number of people being defined as disabled in relation to the general population, and a shif: in ideological perspective pertaining to the needs of the disabled. An attitude swing experienced by the disabled about themselves may have had a number of sources. At the end of the social upheavals during the 1960's decade and in view of successes 
achicved by Black civil rights activists in the United States as well as the Women's movement, disabled persons developed a consciousness conducive to greater exnectations. A laige number of the disabled community was comprised of young disenfranchised people in their late teens and early twenties. ${ }^{137}$ Many of these people had not been gladually socialized into existing conditions of poverty and discrimination but rather suddenly had in forced upon them, chiefly by industrial or automobile accidents. At this lime modern advancements, peacetime prosperity, and societal readiness seemed to contradict the need for passive aceeptance of a socially devalued situation. The result was an increasingly visible disabled minority who vocalized their demands to state representatives. The need to coordinate and fine tune disabled militancy and activism gave rise to a number of specialized lobby groups. Most notable among these structures wele; the Coalition of Provincial Organizations for the Handicapped (COPOH) founded in 1976, People United for Self Help (PUSH) in 1970, Disabled Persons International in 198(), People First representing persons with mental disabilities and the already discussed BCOSS' group). David Lincoln, the President of People First, actually aalled for a revolution as a means to achieve equality for disabled persons. ${ }^{138}$ The People First group inonically emerged as an unintended consequence of the State's directive to deinstitutionalize mentally disabled persons. The covert objective for this move was to silve moncy while contenting kobby groups secking emancipation of mentally disabled persons. Civen the goal of budget reduction through a decrease in social spending it was mot likcly that the government was wiling to allocate necessary resources needed to suppout these persons in the community. ${ }^{139}$ The resulting denial to meet the needs of this 
disabled population led to the formation of the consumer based People lirst gatoup) who demanded full citizen rights, including the provision of resources requised to meet their basic needs outside of an institutional structure. Most of these activist groups, representing different sectors of the disabled, adopted tactics like staging marcles and demonstrations on Parliament Hill in Ottawa (November 3, 198(1). ${ }^{1+0}$ More recently Government programs have been monitored and publicized as failures in terms of real value to the disabled. COPOH demonstrated that Federal Equity Legislation designed to recruit disabled persons to Civil service and other Federally regulated ancass was even less effective for producing desired consequenees then the unregulated private sector. Regardless of the existence of these civil rights groups, arbitrary detention, slavery, and other grossly discriminating conditions are common occurrences confronting disabled persons. ${ }^{1+0}$ As will be discussed in the next chapter, the rights fought for and won by these groups have not proven worth the paper they are printed on willout staict enforcement, monitoring, and progressive judicial interpretation.

Changes in American Public Policy toward disabled persons have depended ujon shifts in the definition of disability thus altering perceptions and the type and nature of program objectives. ${ }^{141}$ American definitions of disability have traditionally developed before the Canadian experience by about five to ten years in each of the categories noted in the previous chart. However the U.S. appears to be lagging as the latest development pertaining to the provision of civil rights unfolds. ${ }^{\text {it2 }}$ Many consume. based groups in the U.S. have been shifted to charitable, paternalistic and social controlling functions white 
Canadian counter-parts have maintained their ideological purity by retaining focus upon resolution of broader issues. The American Constitution's 14th amendment "equal protection" clausc, appears to have contented many American consumers groups without alteing the past system of unequal societa! relations. The predictable consequence has becil only the establishment of paper rights without any real value in terms of mandatory compliance, allocation of resources, or provision of equality of condition. The Disabled in Canada reacted primarily to the, passivity instilling, charity approach and the "sickness" labelling brought about by the medical model. While strategies introduced by American counterparts remained relatively unchanged in the United States throughout the seventies and into the 1980's, the social change focus of the Canadian Disabled consumer movement has set the stage for achieving true equality. Harlan Hahn describes the final goal and desired social status as being;

"In a society truly committed to the principle of providing freedom and equality to all it's citizens including those with disabilities, financial considerations are considered secondary to guarantees of civil rights."

In addition to the activist Disabled consumer movement other factors may have facilitated accomplishment of equal rights provisions for the Disabled. The news media was a major motivator for social change and a device for challenging prevailing attitudes. The media in Canada increasingly began to focus upon the broader discriminatory social issues confronting the disabled, prior to the enactment of legislative amendment. The attention shift was prompted partly in anticipation of 
the declaration of the International Year of the Disabled, and partly in response the increasingly militant Disabled consumer population. Elevated media attention may have been sustained by the many other events occurring in the disabled ficld at tle time. For example, the 14th World Congress of Rehabilitation International took place in Winnipeg in 1980. During this major event, participating disabled persons declared their independence and intention to advocate on their own belalf. They splintered from the professional biased group of medical personnel including doctors, hospital administrators, physiotherapists, and nurses. The rebellion arose after the Disabled were refused equal opportunity to participate in the decision making process. ${ }^{1+4}$ Also at this time the special House of Commons Commitlec on the Disabled and the Handicapped, established May 23, 1980, initiated hearings to solicit the opinions of grass roots groups of disabled persons and individuals from across the country. The product of this process was compiled in a report called "Olsstacles". Several subsequent volumes have since been introduced on the same topic area. Although little real change in social standing for the disabled has resulted from these editions the move can be considered evidence of State recognition that the problem requires some form of response. One of the major recommendations submitted by this committee, in an October 30 th interim report, was to include disability in Human Rights legislation as grounds for claiming discrimination.

Another major incentive for escalating media attention at this time camme from the Disabled consumer movement who were becoming increasingly vocal and cecaled 
enuugh controversy through conflict to attract public altention. For example, in 1976, profiessional research inspired Disabled social movements in the province of Quebec by concluding that disability was actually an inability to access societal institutions and arose overwhelmingly from environmental factors. ${ }^{145}$ "La Force De L.'Exclusion" in Perception Magazine concludes that the Disabled underwent a collective awaking prior to 1980, and became actively involved in self help strategies like unionization.

Other Disabled service groups like the Canadian Rehabilitation Council for the Disabled (CRCD) were active at this time promoting reformation objectives as opposed to focusing solely upon individual's with problems. ${ }^{\text {to }}$ For example, CRCD submission to the Special Committee on the Disabled and the Handicapped contained six relatively advanced recommendations including; expansion of nongovernmental employment opportunities for the Disabled; development of a resource bank for specialized employment aids; legislation creating a more comprehensive definition of accessibility; better outreach services; and modifications to existing Canada Assistance Plan (CAP) and Vocational Rehabilitation of Disabled Persons (VRDP) legislation to compensate for regional economic disparities.

Finally it is interesting to note for the purpose of future strategy development and as an element that sustained activism by disabled groups that labour unions became partial allies. The goals of the labour movenent were recognized to coincide with the need to eradicate discriminatory circumstances for disabled persons, thus 
paving the way for alliance. In the December/September 1980 edition of a labuur magazine the Canadian Labour Congress and the Trade Unionist movement publicly stated their support for full human rights protection and full employment of the disabled. ${ }^{147}$ It is possible that the labour movement finally saw the disabled consumer movement as being significant social force at this time and therefore worthy of support to increase it's representation.

Support from outside of Canada came with the United Nations declaration of 1981 as the International Year of the Disabled. The goal of this excrcise was to produce initiatives that would lessen disparities between the Disabled and $11 \mathrm{~m}$ disabled persons in all societal realms. Related goals of this operation were to create public awareness, stimulate employment opportunities and improve access to community services and facilities. The ultimate goal was the achievement of "full participation and equality" for all disabled persons. It appears that the real value of this campaign was the instillment of Disabled activism through enhanced self-estecn lather than initiating any concrete development. ${ }^{1+8}$

Social movements initiated locally were borrowed from the American experience. The events served to usher an era of reform lead by a new active breed of Disabled who detested chisity and claimed to have consumer/patticipant rights rather than patient/observer status. It should be noted that consumer rights camnot be equated with full human rights provision since the first depends upon possession 
of resources while the second is contingent solely upon being human. Yet the raison d'etre of the consumer group included goals of social change resulting in equal social, economic and political participation. Full human rights were sought including, the right to access public buildings and programs, the right to access private facilities and services, the right to travel without restriction, the right to sexual expression, control over their own rehabilitation process and input into State decisions effecting the status of the Disabled. ${ }^{\text {149 }}$

Ironically the Disabled pointed to their source of rights as being the purchasers of a product, while their power base was rooted in unionization, rather than claiming full rights and privileges by virtue of being human. The Disabled consumer novement did not want charitable relief, believed to be responsible for instilling passivity and apathy, but rather they sought to address and resolve society tolerated injustices based upon discrimination. Henry Enns was part of the World Coalition of the Disabled, representing Sweden, Israel, United States, Canada, India and a mumber of African countries. He stated that the goals of this organization were to end dependency, paternalism, individual focus and professional monopoly, freyuently underlying social programming for disabled persons. Professionalism according to the consumer model is responsible for depriving the Disabled of their political power and personal identity. 
Another example of an activist Disibled consumer group is the Blind Organization of Ontario Self Help Tactics group (BOOSI). BOOST submitted a 29) page report with over 300 recommendations to the Canadian (iovernment prior to the Human Rights Act amendment in 1983. The contents of this report descibed in chapter two, provided evidence of the great degree of variance between disabled and non-disabled groups arising from conditions of discmmination in the areas of self-help, employment, education, poverty, mobility, and especially legislation. This occurrence cites a not uncommon example of the organized, comprehensive, manner with which disabled groups were coming forward to publicize theil oppressed condition in society including resolutions for corrective societal reconstruction. Anong the major sore spots in the disabled critique of the current eslablishment were the obvious inadequacies of the Canada Assistance Plan and Vocational Relabilitation for Disabled legislation. Both of these programs are described by disabled groups as being unnecessarily restuictive and regressively tied to the wellate model. ${ }^{150}$ Remedial action was demanded for providing financial coverage of non-medical costs, lessening regional disparities and providing the means to develop àid promote new innovative programs.

The straw to break the camel's back in terms of sparking disabled militancy was possibly when Bill C-57 (known as the Social Services Act) was introduced on June 20th, 1977. This Bill contained everything that could have been asked tor by the disabled conmunity, but it was never enacted. ${ }^{\text {ist }}$ 
Other piecemeal state responses to the increasingly vocal demands of the disitbled appear in speeches by Health Minister Monique Begin and Employment Minister 1.loyd Axworthy at the World Rehabilitation Conference in Winnipeg. These Cabinet Ministers from the Liberal Party promised research into the problems of the handicapped and a response to their needs as consumers and workers. ${ }^{152}$ What followed was a spattering of affirmative action programs in the public secior, designed to counter past discrimination. These initiatives were contradicted by inconsistencies such as reoccurring discrimination and unavailability of the means to continue working. Enhancement of material conditions for disabled persons through the rather small scale affirmative action programs introduced by the government was effectively neutralized by inadequate transportation services, unavailability of job opportunitics, lack of on the job support, work disincentives created by income assistance bencfit reductions, and lack of mechanisms set up to monitor programming and enforce compliance and especially the predominance of a negative mistaken perspective about disabled persons. Other government action included the previously discussed implementation of a Disabled and Handicapped Committee, interestingly chough having no disabled membership. This body attached to the House of Commons was viewed by consumer groups as a tokenistic publicity stunt designed to pacify the growing movement of disrest. It is likely that this committee served a wert state objective for channeliing opposition to government policy and thus cushioning potentially embarrassing or destabilizing effects arising from disabled concerns surfacing directly on the tloor of the House of Commons. 153 
The policy choice in Canada of limited affirmative action, segregation, and latter provision of paper rights, may have been borrowed from Sweden and the United States. This choice systematically excluded and ignored more effective alternative practices in place elsewhere. For example, West (iermany and Japan, the two most successful modern industrial countries in the world, both pursued more proactive policies of hiring disabled persons atcording to a yuota system in the private sector and fines for nost-compliance. Poland on the other hand prattises complete integration by excluding disability as a social callegory. In 1980, Jean Cretian suggested that the Liberal government would opt for inciuding disability as grounds for discrimination in the Constitution, charter of rights and freedoms. Interestingly enough this plan of action was tirst considered in 1977 but quickly dropped when consequences of financial cost were considered. The era in que:tion marked the desperate attempts of the Trudean government to remain in power after a long and troubled period of rule. The time period shortly after the brief interruption of the Clark government was marked by a great number of concessions to the Disabled, if only on paper. The paper promises were designed to gain needed support from disabled persons to remain in power and as such were not of any great substantial value except to make apparent the potential power of the disabled as consumers and voters. The human rights amendment is safe guarded to avoid altering status-quo operations or enhancing the status of the disabled in any drastic sense by judicial interpretation of vague wording, lack of financial allocation and absence of non-compliance or incentive mechanisms. Similarly the legislation effort 
may have been made ineffective from the onset since a number of citizens and concerned interest groups were said to have equal input into the policies develupnent. The powerful professional and economic interest groups were much more likely to have influenced the final product, while the state structures had tine till. saly in drafting procedures. The final amended version was passed on April 17, 1982, and was soon afterward criticised by the more radical disabled consumer movement as having only face value and no real clout in terms of the implemientation process producing change. The following section will analyze this legislative effort in grealer detail as a means to evaluate effectiveness and better understand the change pocess. First it will be necessary to discuss the escalating popularity of the concept of civil rights as pertains to the Bill of Rights (1960), and the more recently introduced examples in the Charter of Rights and Freedoms.

The notion of individual rights as inherent is said to be rooted in the philos(ophical teachings of John Locke and Jean Jacques Rousseau. ${ }^{154}$ Although individual rights are commonly thought to be undeniable today, in fact such protection is conditional upon privileges recognized and guaranteed by the state. Rights are not absolute as customary belief would hold, but rather are relative and call only be administered to the degree that does not infringe upon the freedoms of others. ${ }^{\text {Is }}$ This may work perfectly in a truly egalitarian society, where everyone starts at the same place and is on equal footing, rights may be distributed equally. However the fact is that in Canadian society some people are more powerful than 
others and as such may be assured more stringent protection of their rights to the detriment of others. Similarly some may require additional consideration to achieve equality of outcome. In Canada, the full force of civil rights and freedoms could possibly result in significant alteration of societal organization and thus elevate the status of presently oppressed groups. This would devalue the higher status of the dominant group. It is therefore in the interests of the state to limit the power of such legislation while at the same time, maximize the public relations and positive inage effect for political advantage.

Rights and freedoms are primarily concerned witl: the relationship) between and among individuals and the state. Canadians first became interested in civil rights as a pistective measure against arbitrary or otherwise unjust state action dus ing and after the Second Worle War. Events like the intennment of Canadian-Japantese and actions by the Quebec government against the Jehovali's Witness icligious groups fuelled concern. Still fresh in the minds of those who were historically inclined wats Canada's past denial of rights to the Acadians of New Brunswick and Nova Scotiat and the Metis of Manitoba. During war time people saw the power which could be mobilized by governments and the ability to violate unlegislited civil rights, as was witnessed in the German policy of extinction tuward Jewish and Disabled persons in Lurope. Ironically people also began to see the potential for government regulation to safeguard such rights as the state began to take a more active role in the private sector. Possibly the horrors of war and the many other changing social phenomenon 
of this time helped to alter perceptions, attitudes, and values toward protection of political, economic, legal, and social rights. In the initial stages, the civil rights movement was confined to the academic circles and in the contents of a large number of newspapers and legal journals in 1947-48. On May 26, 1947, a joint committec of the Senate and the House of Commons on Human Rights and Freedoms was constructed and subsequently recommended that legislation to protect civil rights at the Federal level was not possible since such a mechanism would infringe upon Provincial jurisdiction and necessitate provincial complimentary legislation. ${ }^{150}$ However in the 1950's the Supreme Court of Canada heard a number of related civil rights cases and influential organizations like the Canadian Bar Association actively promoted Federal involvement. More socially progressive opposition parties like the Canadian Co-operative Federation, and especially Alistair Stewart pushed for Federal codification of civil rights on the grounds that; the legal syslem is best suited for dealing with rights disputes; past regulation legislation has provell effect; other Commonwealth countries had such legislation; and legislation could seive as an effective tool for education. ${ }^{157}$ Human rights legislation became an election issue in the 1957-58 contests and in the aftermath the final version of a Bill of Rights was passed on August 4, 1960. Interesting enough, while the Canadian Labour ('ongress and opposition parties had input into the project, the Provincial governments did not. A resurgence of popular interest again emerged in the 1970's possibly sparked by the United Nations Declaration of Human Rights. However the 
state moive for remtroducing a new and improved system of rights protection may have been more out of political rather than altruistic concern.

As was previously stated this policy was largely motivated by political necessity, though it may have been prompted by a drop in party popularity shaped by events occurring abroad. At the time of the original Bill of Rights creation, the "Cold War" between the United States and the Union of Sovict Socialist Republics was at an apex. Canada may have desired to affirm allegiance to western ideas hy coditying commitment to freedom and protection from state, as a portion of the preamble testifies;

"...atfirming that the Canadian nation is founded upon principles...of tree men and free institutions."

In the original text of the Bill however, the limits of citizen civil rights are well detined. The second paragraph states that existing or future laws are not alfected by the bill. In effect, the policy was to operate in a vacuum. In part two it is learned that all rights granted by the act may be suspended under the authority of the War Measures Act as recently in the case of the 1970 FLQ crisis. The War Measures Act states;

Any act or thing done or autiorized or any order or regulation made under the authority of this act, shall be decmed not to be an abrogation, abridgement or infringement of any right os freedom recognized by the Canadian Bill of Rights"15y 
The 1983 amendments to the Canadian Bill of Rights were both comprehensive and long ranging, yet terminally stalled by the hedging elements already discussed. The Bill of Rights enacted in 1959 was linited in authority as a Federal piece of legislation. The lack of power seemed to be remedied when in 1983 the Charter of Rights and Freedoms was entrenched in the constitution and thus could over ride any other Municipal, Provincial or licderal statule. However, the achievement was not as significant as it first appears since many loop holes, subject to judicial interpretation remain intact. For example, discrimination may still be considered a legitimate activity according to paragraph 14 if the action can be considered to be "a bona fide occupational requirement", because of individual fault, authorized by state regulation, based on state determined age restrictions, within reasona:isle limits, or, in cases where "there is a bona fide justification for the denial or differentiation". 'Taken together such conditions can be interpreted as permitting discrimination in any circumstance. For example in the 1987 case of Mahon VS Canadian Pacific Ltd., Mahon wals denied a job as a track man because he was insulin dependant although his diabetes was under control. The Federal court of appeal ruled that such an act was not discrimination on the basis of a bona fide occupational requirement. One socially progressive property of the Act is that, it does qualify affirmative action type programs as being cases of legitimate discrimination, however, in the numerous clauses that follow making direct reference to disability and the powers of the Commission, the many loop holes available to offe:iucrs so that they may avoid prosecution, are discovered. The most notable twol for dismissing claims states that tribundl recommendations should not result in "business inconvenicnce" or "undue hardship". Paragraph 25, discussing the application of either an 
order or a reconmendation, is worded ambiguously and broadly enough that many decisions could simply amount to subtle prompts by the tribunals without any follow up or mechanism to entorce in cases of non-compliance. In 1987, of the 597 cases that came before various human rights judicial commissions, $41 \%$ were dismissed, $12 \%$ were not dealt with, $6 \%$ discontinued, $11 \%$ were not explained, only $8 \%$ were settled immediately, $17 \%$ were sent to conciliation, and $5 \%$ were sent to tribumals. ${ }^{160}$ It should be noted that the dismissal percentage is low when compared to the rates of the past three years. These statistics clearly demonstrate that the legislation is being interpreted in a way by judicial bodies as to diminish any real opportunity to achieve equal, absolute human rights for those opting to use this measure. Human rights legislation has a history in Canada of operational impotence and this endeavour is similarly long on rhetoric and short on practical significance. ${ }^{\text {(ot }}$ fort example the present Charter of Rights non-discrimination clause is the same as the predecessor section $\mathrm{I}(\mathrm{b})$ of the Bill of Rights, which has proven to be without substantive value and only of educational significance. Critiques contend that such exemplified politicians desire to respond to majority influence while at the same time expressing restraint arisıng from ideological limitations. It is submitted here rather that designers are more likely indicating class bias since substantive policy content insures that significant progressive social change will not ensue while at the same time guaranteeing conditions of stability. Dale Gibson notes that the Judges and tribunal members at the operational end of interpreting and implementing the policy are not likely to alter substantive input since they lack the democratic mandate. By politician refusal to address the policy goals of equality for minorities in substance, they have implicitly recognized maintenance of the status quo and 
perpetuated inequality producing systematic discrimination. Sucin legislation therefore may te considered regressive at best. Inclusion in the policy of loop holes like "reasonable limits" as a melhod of protecting one persons right above those of another's leave judicial interpreters little room for manoeuvre unless they want to reshape the substantive authority vested in the policy and risk political backlash. In many cases the relevant commissions do not rule in favour of the plaintiff knowing that their decision would have implicatioals across the country, and thus they could be charged by politicians as attempting to make substantive law. Instead courts are concerned with the balance of rights and not minority rights endowment or compensation for past injustices. It can be predicted that decisions citing policy innovator, grounds of "reasonable accomnicdation"(Bhinder), and "imposition of unduc Hardship" (section 41(4) Canadian Human Rights Act), will sustain systematic discrimimation and construct "reasonable limit" barriers to full rights application to minorities. Any substantive rights contained within are meaningless unless the courts are willing to fully apply remedy powers. The American judicie' experience in Human Rights pronouncements varies in a range from strict to lenient application of remedies depending upon the circumstance, while the Canadian action is said to tend toward indifference and the minimal application position whereby the buiden of proof rests with the plaintiff to demonstrate "bonal-fide justification" (Canadian Human Rights Act section 14(G)). In the 1987 case of Assiad v. CHRC a conciliator was appointed to determine whether the complainant had been discriminated against on the grounds of disability when applying for a job. When Assad relused to comply with the terms of the settlement the claim was dismissed. The question 
remains if delegation to legal courts would not have been a more appropriate and just response than the commission.

It has been hypothesized that the real intent of this last human rights policy introduction as was entrenched in the newly developed constitution, was purely political. Given that Section 15 of this Charter was everything that minority groups wanted in terms of assurances that rights of equality would be protected but had no real operative valuc and was introduced at a time when Prime Minister Pierre Trudeau sought support for the Canadian Constitution as a means to cater to his grand plan of creating a more unificd, and centrally controlled Canada. Commitment was secrelly covertly solicited from civil rights groups and the increasingly powerful teminist and disabled groups with a token gestures appearing to protect the civil rights of minorities and open the door to equality when actually the converse was more correct. The salvation of policy endeavour like the protection of human rights lies in either, the complete reconstruction of substantive contents to more clearly specify goals of equality or in initiative taken by judicial interpretation of policy contents such as the example set by Winnipeg school Division No.1 VS Cratoin (Sejut 1985) when priority of human rights iegislation was recognized above all other law.

Dale Gibson evaluates current human rights mechanisms as follows;

"In a Democracy representatives of the majority are, in good times, generally tolerant of minority interests ....but when the exercise of minority rights would be perceived as conflicting in any significant way with majority interests, minorities cannot expect support from tribunes". 
Thus the advancements to be made under current legislation tools and processes can be predicted to be minimal. In deed the critical examination and anlalysis of the legislation contained here concurs with Gibson's assessment. This latest state response is but a minor variation upon the original Act for the Recugnition and Protection of Human Rights and Fundamental Freedoms (1960), in terms of achieving an objective of equality. Although the Human Rights Act amendments of 1983 and it's subsequent addition to the newly introduced constitution, represents a major achievement by referring to resource, status, and rights distribution and broadly relating to the domains of overall quality of life, living circumstances for individuals and groups, and intra societal human relations, safe guards have been affixed and barriers have not been removed so that the policy may realistically address any desired structural change objective. It is primarily the existence and continued perpetuation of a dysfunctional, devalued, disabled ideology that has given impetus to the misguided beliefs informing policy directives. Combined with the predominance of a certain set of economic values, this mistaken ideology conveniently continues to malign the pure intent of disabled policy, as has historically been the case. Corrective efforts must therefore seek to transform ideology while simultaneously addressing the political element common to all minority majority relations. The following chapter will contain other similar conclusions drawn from the analysis made reference to by the preceding chapters, and thus set the stage for future directives. 


\section{ENDNOTES}

133. John Clark, "The Handicapped Worker", Perception, Sept-October, 1980, Page 11.

134. Paulo Friere, Pedagogy of the Oppressed, New York, Continuim, 1982.

135. Henry Enns, "Canadian Society and Disabled People; Issues for Discussion", Canada's Mental Health, December 1981, Page 14.

136. Patty Holmes, "World Coalition of Disabled Persons", Canlidiaul I abour, May 30, 1980, Page 6.

$13740 \%$ of newly disabled persons are in this age group.

138. "The Disabled Consumer; Challenging the Charity Ethic", Perception, Ottawa, September-October, 1980, Page 27.

139. "Regan Ignores Disadvantaged Americans", Toronton Star, May 26, 1988, and "70\% of Disabled are Unemployed; MP's Told", Montreil Giazette, May 31, 1988.

140. Claude I aforce, "La Longue Marche des Exclus", Perception, SeptemberOctober, 1981, Page 21.

141. Herman Wierengai, "Still Obstacles", Otlawa, epartment of Secretary of Statc, 1983.

142. "La Force De L' Exclusion" Perception, Sept.-Oct., 1980, Page 15.

143. Harlan Hahn, "Civil Rights for Disabled Americans; The Foundation of a Political Agenda", Images of the Disabled, Disabling Images.

144. Iois Browne, "Winnepeg Congress Failed Disabled Consumers", Percejution, Sept.-Oct., 1981.

145. Pierre Joubert, and Rejean Fillion, "The Role of the Environment in the Construction of Handicap; An Analysis of Quebec Relabilitation Practisc", Cinlada's Mental Health, December, 1981.

146. IBID, Page 17.

147. "Cl.C Brief to MP's Committee", Camadian I abour, Vol. 25, No. 15, December 
198(), I etter from National Union of Provincial Gouvernment Employes to Monique Begin, regarding problems with VRDP legislation.

148. J. Daye, "Intermational Year for Disabled Persons; A Time for Doing", Atlantic Provinces I.brary Association Bulletion, September, 1981.

149. Val Ross, "Demanding Access for All; Disabled Activist are Shaping the $N$ w Civil Rights Movement", Maclean's Magazine, April 20, 1981, Page 50.

150. Patrick Johnston, "Disabling Legislation", Perception, Ottawa, Sept.-Oct., 1981, Page 21.

i51. IBID.

152. IBID.

153. Robert Fulford, "Year of the Handicapped", Saturday Night, January 1981, also see Holmes, Patty, "World Coalition of Disabled Persons", Canadian Labour, September 5, 1980.

154. Jean Jacques, Rousseau, The Social Conuract, J.M. Dent, 1762, London 1973.

155. Terri Sussel, and Micheal Manley-Casmir, "Special Education and the Charter; The Right to Equal Benefit of the Law", Canadian Journal of I aw and Society, Vul. $2,1987$.

156. House of Commons Debates, March 14, 1950.

157. Recommendations made by the Special Committee on the Disabled and the Handicapped, Ottawa, Department of Secretary of State, Unpublished, 1983.

158. "All act for the Recognition and Protection of Human Rights and Fundamental Frecdoms", Revised Statutes of Camada, Page 519, Chapter 44.

159. IBIII).

160. Humian Rights Commission Annual Report, 1987.

161. Dalc Gibson, "Protection of Minority Rights under the Canadian Charter of Rights and Freedoms; Can Politicians and Judges Sing Harmony", Neil Nevitte, and Allan Kormberg (ed.), Minorities and the Candian State, Oakville, Masaic Press, 1985.

162. 11311. 
CHIAPTER SIX: TIIE QIJIST OF SOXIAL, CIIANGII ANI) SOCIIEIAI. TRANSITION AS A MI:ANS TO RISSOIVI: A SYSIIIM Ol: MINOIRIIY SUBORDINATION; The alteration of ideologg to cuhance material conditions for minority groups.

A historical critical analysis of state responses to the requirements of disabled groups reveals llat social policies can be considered deceptive and even counter productive in terms of achieving anything other than the furthet perpetuattion of existing societal arrangements. However the Canadian government: applears destinced for a relurn to previous ambivalent disabled/non-disabled selations and as such an implied denial of responsibility. In a letter dated October 25, 1983, from Romald Kanary, National Chairperson of COPOIt, to the then prime minister, Picre Trudeau, the concern was stated that program funding for disadvantaged groups wals being diverted away from the disabled toward the more easily employable groups. Similarly, initiatives like affirmative action, contractual compliance, and fob tratining programs are all being watered down to the point of ineffectiveness. More acecally, in November 1988, COPOH has criticised crown corporations for failing to fultil quotas of disabled hiring legislated under the Eimployment Equity Act. This type of state action taken together with the real intention of Human Rights legislation as has been discerned through critical analysis, represents an insurmountable bartice to the social change sought by more radical disabled groups. While state actions applear on the outside to be meaningful and progressive, such is usually only considered by the state in good times when the demands of minority group members are tolerated, and never includes major alterations. Policies can easily be revoked, nullitied, oI 
overrideden by thr state at any time. Another interesting dynanic occurring in this ste ugg!t: is that the gains of one minority geoup are usually balanced by the losses to olher minorities, thus creating competition and antagonistic relations between groups having similar oljectives. In the case illustrated here, the entrenchment of human rights for disabled persons within the constitution was a significant achievement when comsidered as the consequence of a social action effort. Although this advancement is effectively neutralized by inadequate funding, lack of enforcement, judicial interpretation, and the prevailing negative ideology regarding the disabled, the event in itself represents an important lesson in social change. From an analysis of this occurrence a more premeditaled strategy aimed at producing equitable conditions for the disabled may be deduced. The Human Rights amendment and enclosure within the Constitution was not a substantive victory, but rather could prove invaluable it assessed correctly and utilized to direct future change strategies.

The analysis of this paper seem to demonstrate, as has previously been hypothesized, that in western liberal denocratic capitalist profit-motivated systems, subordinated minority groups must continually fight to achieve and sustain previous gains. Society can adequately be characterised as a perpetual struggle between classes as (opposed to the cooperative relationship purported to be in existence by the dominamt ideology. The consensus society myth is promoted by the state in the face of problems arising from the profit-motivated, capitalist economic system for distributing resources. The dictates of a capitalist economic system driven by 
unyielding motives of efficiency and profit maximization are unlikely to include engaging in any process authorizing temporary or ongoving additional cxpenses, except minimal token gestures designed to stabilize the enviromment and theseby facilitate profit accumulation and capitalist growth. The result of this type of system is 11 flagment social relations and is inherently alienating for a lange percentage of the population. The mechanism charged with maintaining a social enviromment conducive to the flourishing of the economic mode is known as the state. The Marxian perspective on state function is validated by the historical represcintation contained in this paper. That is that the state operates as an agent of societal stabilization and thus social order protection. An analysis of recurring state responses to minority issues provides evidence that members of the state are unwilling, appiehensive, or at least hesitant to address the real needs of the disabled. State action may not be deterministic but rather arises as an indirect consequence of shared class interests, internal ideology restrictions, and political considesations (necessitating the maintenance of powerful and influential positions). Pitternalistic and charitable actions toward minority groups are well meaning, but always fall short of goals of equality. Minority concerns or issues are usually labelled as social problems, which are identified for consideration by the state as a matter of convenience during periods of societal destabilization, or when issues othelwise interfere with the capitalist reproduction processes. Social policy is the usual velicle for providing remedial efforts while increasing social control. For example, internalized restriction is innate in the case in charity provision. (iiven that the state 
functions as a mediator of class conflict, and duc to composition and membership, actions are generally biased toward benefitting the upper class, social policies are therefore designed to protect an image of neutrality. Other related state functions oficn bolstered through social policy are protection and support of status quo arrangenents and promotion of positive public relations. Most state sanctioned social institutions exhibit the same covert objectives. The shape and form taken within the realen of social policy is dependent upon a number of situational and varying clements including, for example: chance events, public opinion, level of economic prosperity, position in the election cycle, degree of societal differentiation and techmology advancement, power of relevant lobby groups, amount, type and source of extermal pressure, and ability of relevant actors to politically mobilize. Thus to eutirely understand social policy one must not only consider public announcements, but also scrutinize specific contents, intended purposes, political objectives, basic belicls, values, ideology, other religious elements, actual consequences, implementation regulations and processes, other beneficiaries and the total cumulative eflect of other related policies or state actions in the broader context. One nutable example of social policy isolated here is the provision of charity which recmerged from the ashes of the English poor laws during the 1950's to become institutionalized as a common state response. However charity is inherently a mode of social control since it diminishes the receiver's self-esteem while simultaneously empowering the provider. In this same way current social policies identifying minority groups as the problem are restricting and disempowering producing final 
consequences of dependency and passivity. All of the policies studied here have been primarily motivated by political intention and a requirement to gain or sustain power. All can be considered ineffective strategies of liberalist reform and even regressive in terms of achieving disabled equality. Policies cannot be evaluated as if operating in a vacuum since such are related to and affected by other state policies, state antion or inaction, socictal circumstance and prevailing values and ideology. In the broader Canadian context, social policies, political intentions privatc intluchec, and especially economic policy, are intricately interwoven. This paper demonstrates the connection between disabled policy and the inclinations of the labour market. Regardless of motivating circumstances it is useful to remember that all social policies and societal organizations have multiple and superficially conflicting purposes arising from the dual state role of social control and promotion of positive public relations (otherwise known as legitimization). However, in the final result the acts of social control tend to be real, whereas humanistic public relations efforts lend to be illusionary. From the information discussed so far it can be concluded that social equality for disabled persons is not possible within the prevailing Canadian jdeological framework. The same maid be said for existing social institutions. The present shape and form of state sponsored institutional structures will not accommodate conditions of equality for disabled persons or any other type of munority.

While the users or subjects of social policy are seldom, if ever, dirceclly involved in this development, policies relating to the social aspect of living do 
represent an arena for struggle hetween opposing class interests. In the purely alstract sense, social policy as a tool for addressing problematic aspects of society is neutral until infected by the objectives of the inventor. For example, the nature of a given policy is altered drastically, depending upon whether an objective is securing the status quo, social control, reformism or structural social change. Ideology seems to be a key variable for determining the objective of any policy. Idecology is also a potentially neutral element, although in the Canadian context the dominant state sponsored conservative ideologies serve to inhibit progressive change while socially progressive ideologies instigate alteration in favour of achieving equality. ldeology, in the restrictive sense, may be employed to legitimate prevailing customs, rituals, beliefs, and other traditions, thereby validating and perpetuating the existence of the prevailing social order. As the examination in this paper demonstrates, prevailing ideologies in Canada represent to a large extent the greatest oppressor, because of restrictive capacity and the ability to instill apathy. Such inherently limiting and myth-riddled ideology thereby represents a barrier to potential minority activism. Ideology is seeded within minorities (by way of various social processes and especially through social policies) to produce an internalized sense of inferiority subsequently inducing contentment and passivity as elements of social control. This occurrence is common among all minorities, but most recently has becil articulated by women's groups in criticisms of sex stereotyped socialization practices. 
So far the connection has been established between devalued status and conservative ideologies. However, material conditions and ideological beliet's do not exist in a cause and effect relationship, but rather are intertwined and interdependent. The end result is a unconsciously structured but intentionally maintained system of inequality conducive to capitalist profit-motivated growth and development. Of course, in such a system where resources are distributed unequally, those who are in powerful advantaged positions will be the most resistant to change, while those disadvantaged, notwithstanding the effect of ideology, will be eager of gain status. In the case of disabled inequality arising from general intentional and unintentional discrimination and socially, internally instilled sense of apathy, their diminished situation is compounded by the broader system of structured social inequality. For example, a disabled person maly face situational, structured, and systematic harriers to economic prosperity on the grounds of regional disparity, discriminatory practices, and predominance of traditional methods that disqualify persons with certain characteristics. They become the poorest of the poor, or in Marxian terms can be labelled the lumpenproletariat. Only elevated social status, enhanced material conditions and re-education can resolve the long standing damage produced by conservative social policies.

The role of social for disabled persons policy in maintaining these subordinated conditions has been well established in the defiction contained here. The disabled, being among the most discriminated against and socially disadvantaged 
of any minority class, must rely heavily on social policy as a remedial device. Social policy toward the disabled is characterized by minimal benefit, rigid eligibility criteria and often applied as a trade off for civil rights. Given that the social status of all minority groups has remained relatively unchanged in comparison to advantaged groups it is assumed that all minority relevant social policy is similarly ineffective in terms of regressive actual consequences. While disabled policy has evolved in a progressive direction over the last half eentury, irom total indifference to formal civil rights, it still remains ineffective in terms of producing full equality, primarily because of the underlying discriminatory ideology which dictates substantive action. No mater how comprehensive legislative endeavours are, the effectiveness of policy is dependent upon the willingness of the implementors. Trends in the disjointed incremental evolution of disabled social policy correspond to shifts in the general social welfare policy field which were similarly related to chance events, external and internai circumstances. and economic and/or political policies. Policy for disabled persons has not achieved stated purposes, and has in fact been detrimental to the target population. The creation of poslicy in Canada has also historically ignored progressive alternatives proposed in favour of state hidden agendas. Although . $i_{-}$iy progressive alternative policies have existed elsewhere and been available at times when Canadian disabled social policy was being developed, such choices were ignored or overlooked. State representatives have only superficially responded to the demands of disabled persons in principle. Such actions have little practical significance for disabled persons except to reinforce everyday repressive 
circumstances. In Canadian liberal democratic society, power is the crucial varialile for either denying, initiating, or determining the type of social change. The power variable obviously separates classes while at the same time, lack of which, may provide a commonality between minority groups and incentive for unification.

All minorities are confronted by the same or similar elements of discrimination and socially unjust circumstances. All are commonly subjected to some form sof social disability, based on possession of a unique characteristic that identifies them as being different from the core, advantaged population. Thus the issues to be resolved in any situation are the same and the plight of minorities and all citizens is vied together. In pragmatic terms this last statement is given validity by the fact that state response to one minority group is hinged upon intolerance of another and tied to the potential treatment of all citizens. Given that state priorities and envelope spending affect a majority of citizens equally, the parameters of disability may be considered relatively' open and a concept of social disability tirmly established:

From an analysis of the information thus far it becomes apparent that social change frequently occurs in times of real and perceived social upheaval and crisis, while reform occurs primarily in times of economic or political instability. The actual process of transformation is facilitated by the existence of any of a number of social conditions. For example, media publicity, shifts in public consciousness, advancements in technology, large scale chance events, destabilized or threatened 
environment structure, changes in population composition or structure, or the existence of well organized and powerful social movements, to name a few, may Iesult in some degree of societal reformation. The presence of at least a few of these clements is necessary to produce social change, like a different motive for distributing resources is or a sudden shift in the nature of majority-min:srity relations. Conflict, by whatever means, is the mechanism by which change occurs. The product of such change is contingent upon strength and organization of socially progressive elements.

It is submitted here that advances in tisabled material conditions, prosperity and general status can be attributed more directly to disabled organization and activism, as opposed to any other one solitary social phenomenon. A consensus has developed among disabled persons and groups attesting that traditional state responses to resolve the subordinate position of the dis: ibled have been inadequate. Most disabled persons agree that a negative disabled schemata is widely prevalent among societal members and at the root of well intentioned but off base state decisions. Furthermore, consumer group tactics and self help methods have proven more responsive to acquiring conditions of equality than have traditional state sponsored policy endeavours, as long as autonomy from the state is maintained and organizations remain severed trom activates like charity provision. Unionization among disabled organizations has worked well in snall scale applications as a strategy for influencing the political and advancing logical change. However the potential for expanding coalitions beyond the rather artiticial parameters of disability and thus 
broadening the base of political power and intluence remain relatively unrealized. For example, in the case of labour unions, having many of the same goals and desires, an obvious opportunity exists to form an alliance. Other potential links could be forged between groups like socially progressive social work associations, schools of social work, black groups, women's groups, ethnic groups, left-wing political parties, social agencies and organizations, religious groups, and larger in... . ־lional associations, among others.

Based upon the discussion thus far, political goals, ideological influence, and social-psychological impact of the policy upon the target population appear to make the goal of total societal transformation the only plausible solution. However alteration of this magnitude must unrealistically entail no less than the proverbial revolution of the proletariat. Instead it may be more practical to focus upon specilic processes and segments of the state when attempting to achieve social change objectives. For example, a major goal of a radical strategy may be to replace the criteria for resource distribution in minority programming, from pro'it and efficiency motivated to a guarantee of minimal standards. The concept of a guaranteed minimal standard of living is not strictly adhered to or entorced, but is a widely shared goal.

Another goal may be to replace prevailing ideologies and philosophies with more socially progressive, equitable, and humanitarian beliefs. In operational tems 
this commitment would preclude taking advantage of the various social agencies responsible for administering the socialization process. The core curriculum promoted in schools, the advertising media, and traditional family units would need be subjected to critical analysis and strategic intervention. Counter promotion efforts may be utilized in this respect to battle jdeology and raise individual levels of consciousness.

The desired result is to achieve a society where the motives for human existence no longer include individualism, profit motivation, exploitation, and competition, as is now the case for a large percentage of the population. As a means toward realizing this prime objective of equality, major alterations of state structures most transpire. For example, minorities must have true access and input into all levels of the decision making process and societal living. True access means that such involvement cannot be diminished to the level of token gestures or assimilative procedures that tend to corrupt minority consciousness. Instead this type of involvement should be on parity as a means to effectively counter balance the existence of pre-determined power structures and misguided priorities. To achieve the above noted broad scale goals, conflictual strategies of intervention must be developed to optimize success. Some of the following strategies have already been enacted to various extents, but as is submitted here, they were doomed to only minimal or incomplete success since the necessary power and resource base was not first established. It is submitted here that the creation of competing social institutions 
may provide necessary elements toward the building of a new social order.

In view of the fact that social change is a complex and many sided phenomenon involving the blending of chance events, contemporary social conditions, other societal occurrences, various power structures and relevant actors, those secking social change should observe or work to create an atmosphere conducive to redevelopment. Recently the Coalition for Provincial Organizations of the Handicapped presented a report attesting to the failure of the Employment Equity Act and other Crown Corporation affirmative action programs. Ifowever this well presented criticism may have made a greater impact if it had of been submitted a month earlier before the Federal Election was decided or when the llouse of Commons was sitting. As was mentioned earlier, the nature and composition of the Canadian liberal democratic system necessitates possession of a large amount of power when seeking to initiate social change. Thus, in the case of minorities, a large membership committed to objectives of social change need be established. Potentia allies to be drawn from have been discussed previously. Care must be take however, when selecting from such a diverse pool, to over ride individual anci grouI differences by emphasizing achievement of the final objective above all else. Thi nature of the Canadian social structure makes politicization not only unavoidable bu also desirable. Relationships between minority and majority persons automaticaili entail an unbalanced political component and through politicization of a unifier minority group, a counter weight to state power may be implied. In today's contcx 
this type of movement can be considered a radical self-help technique. Alliance and coalition building are proposed as being very effective in three recent, case studied, examples; Winnipeg Family Allowances; Quebec Foster Care; and Saskatchewan Legal Aid; by the National Council of Welfare.

As a means to procure an environment for, and level of public consciousness conducive to the implementation of social change strategies, activists may wish to engage in the following ploys. First it is necessary to consistently monitor and record state promises and actual responses to minority issues. The yield of this activity can then be analyzed and publicized at a convenient time when the output will have the maximum result. Furthermore the outstanding conditions of discrimination and the devalued social position of minorities should be publicly stated and especially brought to the attention of potential and present, allies and members. Included within this objective is the requirement to engage or attract the support of relevant promotional social institutions including, various segments of the mass media, schools, churches, social work institutions, and any other organization in touch with or having grass roots membership. This may be done for example by net-wotking with key people in each of the organizations or by $s_{i}$ onsoring presentations at different locations. Other specific tactics include submitting letters, articles and other material to media telations, opposition members of parliament, and/or in academic circles. One final strategy worthy of mention because of past suceesses, is the cultivation and usage of external pressure sources to incite domestic action. The altention of powerful 
external organizations may be solicited directly or through the media by sponsoring international conferences or presenting submissions on related subject matter at external work shops. The attempt and coordinate all of these activities, a revolutionary political body will need to le developed.

Education is a key component to social shange. Organized activity agencies should seek to influence and alter the public education in a manner which would counter act discriminatory perspectives about disabled persons as well as conf ront the motions at the heart of the prevailing conservative ideologies. An alternate curriculum should emphasize disability as being equal, normal, and emplasize sameness of condition between different types of disability as opposed to high lighting the need to segment populations into groups based on type of impairment. At the elementary, secondary, and post secondary levels of education all aspects of the educational system must be opened to persons with disabilities through concerted and consistent lobbying. Much of the criteria for initial programming should be geared toward re-education and allow disabled persons to define their own needs, according to a consumer gruap format.

The salvation of the disabled in the quest to resolve discriminating perceptions and circumstances of inequality, rests with goals of unionization and organization between and among various other societal elements, and minority intiltration of state power and decision making structures. The deeply entrenched slanderous disabled 
ideology can now only be altered through equality of material conditions and at least partial socictal transformation achieved by minority activism. The current societal structure and practises do not meet the needs of and discriminate against a number of minority groups, who cumulatively represent the majority. Structural social change depends upon the unification of these forces. 


\section{APPENDIX I}

Participation Rate by Disability Status, Sex and Age (jroup (Persons Age 15 and Over)

\begin{tabular}{|c|c|c|c|}
\hline \multirow{2}{*}{ Sex By Age Group } & \multicolumn{3}{|c|}{ Disability Status (\%) } \\
\hline & Total & Disibled & Non-I Disabled \\
\hline CANADA ALI. AGES & 64.4 & 31.6 & 69.2 \\
\hline 15-34 years & 73.0 & 59.2 & 73.6 \\
\hline $35-54 "$ & 79.3 & 56.8 & 81.7 \\
\hline $55-64 "$ & 52.5 & 30.4 & 59.8 \\
\hline $65+"$ & 7.6 & 4.2 & 9.8 \\
\hline MALE & 76.8 & 41.2 & 81.6 \\
\hline 15-34 years & 81.0 & 67.8 & 81.6 \\
\hline $35-54 "$ & 94.4 & 70.1 & 96.8 \\
\hline $55.64 "$ & 72.7 & 42.3 & 82.6 \\
\hline $65+$ & 13.4 & 7.5 & 17.0 \\
\hline FEMAIF & 52.5 & 23.6 & 57.1 \\
\hline 15-34 years & 65.0 & 51.5 & 65.7 \\
\hline $35-54 "$ & 64.1 & 45.4 & $66-4$ \\
\hline $55-64 "$ & 34.11 & 19.6 & 38.8 \\
\hline $65+$ & 3.3 & 1.7 & 4.3 \\
\hline
\end{tabular}


APPENIDIX II

Disability Status by Age Group and Current Education Level

\section{CANADIAN TOTAL}

TOTAL DISABLED NOT DISABLED

TO'AA.

19,136

2,448

16,688

Girades $0-8$

3,934

1,066

2,868

High School

3,559

1,007

8,552

Somie post

1,622

111

1,511

secondary

education

Post secondary

certificalte

2,162

168

1,994

or diploma

University

1,858

95

1,763

degree 


\title{
APPENDIX III
}

\section{Disability Status by Age Group and Current Education Level}

\author{
Alges 15 (1) 34
}

$\begin{array}{llll}\text { TOTAL } & 8,670 & 395 & 8,275 \\ \begin{array}{l}\text { Grades } 0-8 \\ \text { High School }\end{array} & 561 & 69 & 492 \\ \begin{array}{l}\text { Sorme post } \\ \text { secondary } \\ \text { education }\end{array} & 5,062 & 232 & 4,830 \\ \begin{array}{l}\text { Post secondary } \\ \text { certificate } \\ \text { or diploma }\end{array} & 1,086 & 35 & 1,1051 \\ \begin{array}{l}\text { University } \\ \text { degree }\end{array} & 1,121 & 39 & 1,1882 \\ \end{array}$


APPENDIX

Disability Status by Age Group and Current Education Level

Ages 351054

TOTAL

$5,840 \quad 581 \quad 5,258$

grades $0-8$

$1,283 \quad 202 \quad 1,080$

Iligh School

2,702

262

2,439

Some Post

358

30

328

secondary

education

Post secondary

certificate

735

53

681

or diploma

University

762

33

730

degree 


\section{APPENDIX V}

\section{Disability Status by Age Group and Current Lducation I evel}

Ages 551004

\begin{tabular}{|c|c|c|}
\hline TO'TAL. & 2,270 & $56 \mathrm{i}$ \\
\hline Grades (1-8 & 889 & 274 \\
\hline High School & 968 & 221 \\
\hline $\begin{array}{l}\text { Some Post } \\
\text { secondary } \\
\text { education }\end{array}$ & 102 & 19 \\
\hline $\begin{array}{l}\text { Post secondary } \\
\text { certificate } \\
\text { or diploma }\end{array}$ & 165 & 29 \\
\hline $\begin{array}{l}\text { University } \\
\text { degree }\end{array}$ & 145 & 18 \\
\hline
\end{tabular}




\section{APPENDIX VI}

\section{Disability Status by Age Group and Current Education Level}

\section{Ages 65 plus}

\begin{tabular}{|c|c|c|c|}
\hline TO'IAL. & 2,356 & 910 & 1,446 \\
\hline Grandes (1-8 & 1,200 & 521 & 680 \\
\hline 1 ligh School & 828 & 291 & 536 \\
\hline $\begin{array}{l}\text { Some Post } \\
\text { secondary } \\
\text { education }\end{array}$ & 77 & 27 & 50 \\
\hline $\begin{array}{l}\text { Past secondary } \\
\text { certificale } \\
\text { or diploma }\end{array}$ & 141 & 47 & 94 \\
\hline $\begin{array}{l}\text { University } \\
\text { degree } \\
\text { certificate } \\
\text { or dipluma }\end{array}$ & 111 & 25 & 86 \\
\hline
\end{tabular}




\section{APPENDIX VII}

Unemployment Rate by Disability Status, Sex and Age Group

Total Canadlian Disalbility Stallus

Total Disabled Not Disabled

$\begin{array}{llll}\text { TOTAL } & 10.0 & 12.0 & 9.8 \\ 15-3+\text { yrs } & 13.2 & 18.4 & 13.0 \\ 35-54 \text { yrs } & 6.8 & 11.4 & 6.4 \\ 55-64 \text { yrs } & 6.7 & 9.9 & 6.2 \\ 65 \text { yrs }+ & -- & -- & -.\end{array}$

Canadian Male Disability Status

Total Disibled Not Disibled

$\begin{array}{llll}\text { TOTAL } & 9.6 & 12.5 & 9.4 \\ 15-34 \text { yrs } & 13.4 & 22.0 & 13.1 \\ 35-54 \text { yrs } & 6.0 & 10.0 & 5.7 \\ 55-64 \text { yrs } & 0.5 & 8.9 & 6.1 \\ 65 \text { yrs }+ & -- & -- & --\end{array}$


(andadian Female Disability Slatus

Total Disabled Not Disabled

$\begin{array}{llll}\text { TOTAL. } & 10.6 & 13.0 & 10.5 \\ 15-34 \text { yrs } & 13.0 & 14.3 & 12.9 \\ 35-54 \text { yrs } & 8.0 & 13.2 & 7.6 \\ 55-64 \text { yrs } & 7.5 & 11.9 & 6.5 \\ 65 \text { yrs }+ & -- & -- & \ldots\end{array}$




\section{BIBI JOGRAPIYY}

Abello, Irving(ed.), On Strike; Six Key Labour Struggles in (allaldia, 1929)-1940, Toronto, Jones Lewis and Samucl, 1974.

Adams, Henry E., Abnormal Psycology, WMC Brown, lowal, I98I.

Albrecht, Gary L., The Socialization of Physical Disiability Rehabilitation, Unver sity of Pittsbutg Press, 1976.

Albrecht, Gary L., and Judith A. Levy, Cross Nattomal Rehabilitation Pollecies, Universily of Pittsburg Press, 1980.

Arterton, Christopher R., and I larlan Hahn, Political Participallion, American Political Science Association, Washington, 1975.

Artherton, Charles R. and David L. Ḱlemmack, Research Melhods in Siocial Wouk, D.C. Heath, Toronto. 1982.

Baker, Maureen, The Disabled and the Ilindicapped, Political and Social Allains Division, I House of Commons Library, Otlawa, 1987.

Berkowitz, Monroce, and Anne Hill, Disibillty and the Labor Millhet, 1.L.R. Prass New York, 1986.

Berkowitz, Edward D., Disabled Policy; Americas Programss tor the: Limediandnedd, Cambridge University Press, Cambridge, 1987.

Berkowitz, Monroe, and William G. Johnson, Public Pollicy Toward Disilbility, Praeger, New York, 1976.

Bernard, Thomas O., The Consensus Conflict Debate, Harper Row, Ncw York, I983.

Biklen, Douglas, The Culture of Policy: Disabled Imaiges and Their Analugues in Puhlic: Policy, Policy Studies Journal, Vol.15, No.3, March 1987.

Blau, P.M., The D, namics of Bureacrocy, (hicago, Universily of (hicalg(, 1955.

Bowe, Frank, Handicanping America; Barriers on Disabled People, Harper Row, New York, 1982.

Brave, Frank, "The Dynamics of Public Policy and the Development of the Developmentally Disabled", ouncil State Gouvernments, July, 1978. 
Bridge, N.J., and Gold Deborah, "An Analysis of the Relationship Between Liesure and Ficonomics", Page 10-15, Journal of I iesurability, Vol. 16, No. 2, Spring 1989.

Brown, Joan C., A Hit and Miss Affair: Policies for Disabled People in Canada, Canadian Council on Social Development, Ottawa, 1977.

Canadian Iluman Rights Commission, "Discrimination in Canada; A Survey of Knowledge, Attitudes and Practices Concerned with the Disabled", Ottawa CHRC, 1978.

Calholic Institute for International Relations, Right to Survive; Human Rights in Nicillaguat Russell Press, London, 1987.

Chambers, Donald E., Social Policy and Social Programs, MacMillan, New York, 1986.

Clarke, Harold D., Allan Kornberge and Marianne C. Stewart, "Active Minorities Political Participation in Canadian Democracy, Minorities and the Canadian State.

( 'lakk, J.l., "Fereral Legislation in Canada Revalent to Disability and the Disabled", Unpublished Paper, April, 1980.

Clement, Wallace, The Canadian Corporate Elite, McLelland and Stewart, Ottawa, 1975.

Coudroglou, Aliki, and Dennis L. Poole, Disalbility Work and Social Pollicy, Springer, New York, 1984.

Ciewe, Nancy M., and Irving Kenneth Zola, Independant I.iving for Physically Disalbled Peciple, Jossey Bass, San Francisco, 1983.

Chrichton, Anne, "Developing Rehabilitation Policies in Britian Canada, and Austraillia: A Comparison", Cross National Rehabilitation Policies, 1981.

('ross, Micheal S. and Gregoty S. Kealey, Modern Canada, 1930-1980's, M"Clelland and Stcrart, Toronto, 1984.

Dedck, R.A., and W.H. Macy, "Public Policy and Social Responsibility with Regard 10 Rehabilitation and Maintenance of Disabled Persons", Technological Forcasting ind Social Chimge, 1980.

1)jao, A.W., Ineguility and Social Pollicy, John Wiley + Sons, Toronto, 1983.

Donges, Gregory S., Policy Making for the Mentally Llandicapned, Gower Press, Cilcat Britian, 1982. 
Gil, David, Unravelling Social Policy, Schenkman, Massachausetıs, 1981.

Gouer, D., Labour Market Activity of Disialled Persons in Callida, Ottawa, Labour and Household Survey Analysis Division, Statistics Canada, 1988.

Guest, Dennis, The Emergence of Social Security in Callada, Vancouver, 1981.

Hagerty, C.J., "Impediments to Integration; National Policy Change for Mentally 1 landicapped Students", Exceptional Children, 1987.

Hahn, Harlan, "Disability Policy and the Problem of Discrimination", Amesician Bchavioural Scientist, 1985.

Hahn, Harlan, "Paternalism and Public Policy Toward Disability", S(xcicty, 20, 31-41), March-April, 1983.

Harp, John, and John R. Hafley, (eds), Structured Inequality in Caniada, Scarborough, Ontario, 1980.

Haveman, Robert H., Victor Halberstadt, and Richard V. Burkhauser, Public Pollicy Toward Disabled Workers, Cornell University Press, Illinois, 1984.

Hepworth, Philip, Personal Social Services for the Handicapped, Canadian Council on Social Development, Ottawal, 1977.

Himelfarbo, Alexander and C. James Richardson, Sociology for Cimludians, Toronto, M'raw-I lill Rycrson, 1982.

Hirst, Michacl, "Social Security and lnsequrity; Young Pcople With Disabilitics", International Social Security, 38; 258-72, No.3, 1985.

Hoverman, Robert H., Victor Halberstadt and Richard V. Burkhauscr, Public Pollicy Toward Disabled Workers, Cornell Unversity Press, Itasca, 1984.

Howards, Irving, Henry P. Brehn and Saad Z. Nagi, "Communication and Physically Handicapped; A Literature Review With Some Policy Implications", Gov. Dox., CAI co 125-79C56.

Illich, Ivan, Irving Kenneth Zola, John McNight, Johathan Caplan, Harley Shatkcn, Disabling Professions, Masion Buyers, 1977.

Joe, Tom, and Alan Gartner, Images of the Disabled: Disabling Iminges, Pracger, New York, 1987. 
Johnston, P., "Submission to the Special Committee on the Disabled and the Handicapped", Canadian Council on Social Development, Ottawa, 1983.

Johnson, William G., "Symposium on Disability Policy", Policy Studies Journal, Vol.15, No.3, March 1987.

Knoff, Rainer, "The Statistical Protection of Minoritioes: Aftirmative Action Policies in Canlada", Minorities and the Canadian State.

Iece, Gloria and Ray Loveridge (ed.), The Manufacture of Disadvantage: Stigma and Social Closure, Open University Press, 1987. (ISBN 0-335-15503-0)

Ludwig, E.G., and J. Collette, "Dependancy, Mental Health and Social Isolation in the Disabled Population", Social Psychiatry Vol.5, Pg92-95, 1970.

Marchak, Pal, ldeogical Perspertives in Camada, Toronto, $M^{c}$ raw-H Hill Ryerson, 1981.

Marx, Karl and Frederich Engels, The German Ideology, New York, International, 1970.

Masson, Gerard, "Aide aux Handicapes et Changement de Societe", Re. Soc., page 55-65, March 1983.

Mck'louskey, Larry, "The Inequalities of Social and Physical Disability in the Pursuit of Normalization", SSWIEP 227, 1982.

Metton, Robert K., Society and Social Pollicy, London, M"Millan Press, 1972.

Miller, S.M. and F. Ressman, Social Class and Social Policy, Basic Books, New York, $1 \% 8$.

Mishra, Ramish, Socicty and Social Policy, London MacMillan Press, 1977.

Monroc, Beıkowitz et al., Public Policy Towards Disability, New York, 1981.

Moscovitch, Allan, and Glen Drover, (eds), Inequality: Essays on the Political licomomy of Social Welfare, Toronto, 1981.

Nevitte, Neil, and Allan Kornberg, Minorities and The Canadian State, Mosaic, Oakville, 1985.

Nordguist, Jnger, A life Together: The Situation of the Handicapped, Stocholm, 1975. 
Oberschall, Anthony, Social Conflict and Social Movements, New Jerscy, Prentice Iall, 1973.

Palticl, Freda L., "The Disabled in Canada - An Introductory Overvicw", unpublished paper, 1980.

Panjtich, Leo, The Canadian State: Political Fionomy and Political Power, Toronto, University of Toronto Press, 1977.

Pfeilfer, David and Michael Gianpeitro, "Government Policy Toward I landicapped Individuals", Policy Structures, pages 93-101.

Platt, Anthony, The Child Savers; The Invention of Delinguency, (hicago, Univessity of Chicago Press, 1969.

Pressman, Jeffrey I., and Aaron Wildausky, Implementation; The ( )ilklimd Project, L.os Angeles, University of California Press, 1984.

Porter, John, The Vertical Mosaic; An analysis of Social Class and Power in Calladia, Toronto, 1982.

Rao, V., "Services for the llandicapped Persons - Organization and Policy Implications", Indian Journal of Social Work, 1983.

Rein, J., Social Policy: Issues of Choice and Change, Random Housc, Ncw Youk, 1970.

Reynolds-Maynard, C., "Synopsium un Public Policy and Education I Handicapped Persons", Policy Studies, R. 2:1-263

Roeher, G. Allan, "Rehabilitation in the Eighties: Challenge for Change", unpublished pajer, March 1980.

Rubin, Jeffrey (ed.), Altermatives in Relaabilitating the Handicapped: A Policy Analysis, Human Sciences, Pr. 1982.

Satilios-Rotheschild, Constantina, Women and Social Policy, Prentice-llall, New Jersey, 1974.

Safilios-Rotheschild, Constantima, "Disability and Rehabilitation Research in Developing Countries", Cross National Rehabilitation Policies.

Scotch, Richard, From Gondwill to Civil Rights: Translonming Federal Disialilily Policy, Philadelphia, Temple University Press, 1984. 
Secretary of State of Canada, Profile of Disabled Persons in Canada, November, 1080.

Silbur, D., "Fair Policy tor the Disabled", Macleans, 96:60, 68, N14, 1983.

Simith, Richard, 'T. Gergert, and J. Alfred, "Social Policy Issues in Invalidity Programs; A Cross National Perspective", Cross National Rehabilitation Policies.

Sokolowska, Magdelena and Alıtonina Ostrasky, "Creation and Removal of Disability as a Social Category; The Case of Poland", Cross National Rehabilitation Policies.

Stone, Deborah A., The Disabled State, Temple University Press, Philadelphia, 1979.

Sutlus land, Allan T., Disabled We Stand, Souvenir Press, London, 1981.

Topliss, Eda, Social Responses to Handicap Social Policy in Modern Britain Great Brilain, 1982.

Toward, L. M., "Survey of Atlantic Provinces Legislation with Respect to Disabled Puscons", APL.A Bul., 45, July 1981.

Tsalikis, (jeorge, "The Consequences of Canadian Health Care Policies", Canadian Council on Social Development, Issues in Canadian Social Policy, 1984.

Tuck, Mary, Alcoholism and Social Policy: Are We on the Right I.jnes, Pendagon, (ircal Britain, 1980.

United Nations, Disibility; Situation, Strategies and Policies, New York, 1986.

United Nations, The Integration of Disabled Persons into Community l.ife, New Yolk, 1986.

Unterberg, H., "Sucial Policy and the Young Disabled", International Social Security Assincialion, 1985.

Vance, Elizabeth Taylor, "Social Disability", American Psychologist, Vol.28, June 1973.

Verville, R. E., "Iisabled, Rehabilitation and Current Public Policy", Journal of Rohabilitation, 1979.

Weler, Max, The Protestant thic: and the spirit of Capitalism, New York, Scribuer, 1958. 
"Recent Trends in Legislation Concerning Rehabilitation Services for Disabled in Select Countries", Gov. Doc., UN/ST/ESA/7-3.

"The Freedom to Move is Life Itself; A Report on Transportation in Ontario", Ontario Advisary Council on the Status of Senior Citizens, ttawa, 1987.

"Tell Me What's Normal", Reader's Digest, 119: 87-90, July 1981.

"The White House Congerence and the Workd: Delegates Who Will liormulate New National Policies for the Handicapped Should Study Foreign Success", Rethabilitation World, 3(1): 3-9, 46-47, 1977.

"Support for the Handicapped in Sweden", The Swedish Institute, Fiat Sheet on Sweden, Febuary, 1980. 

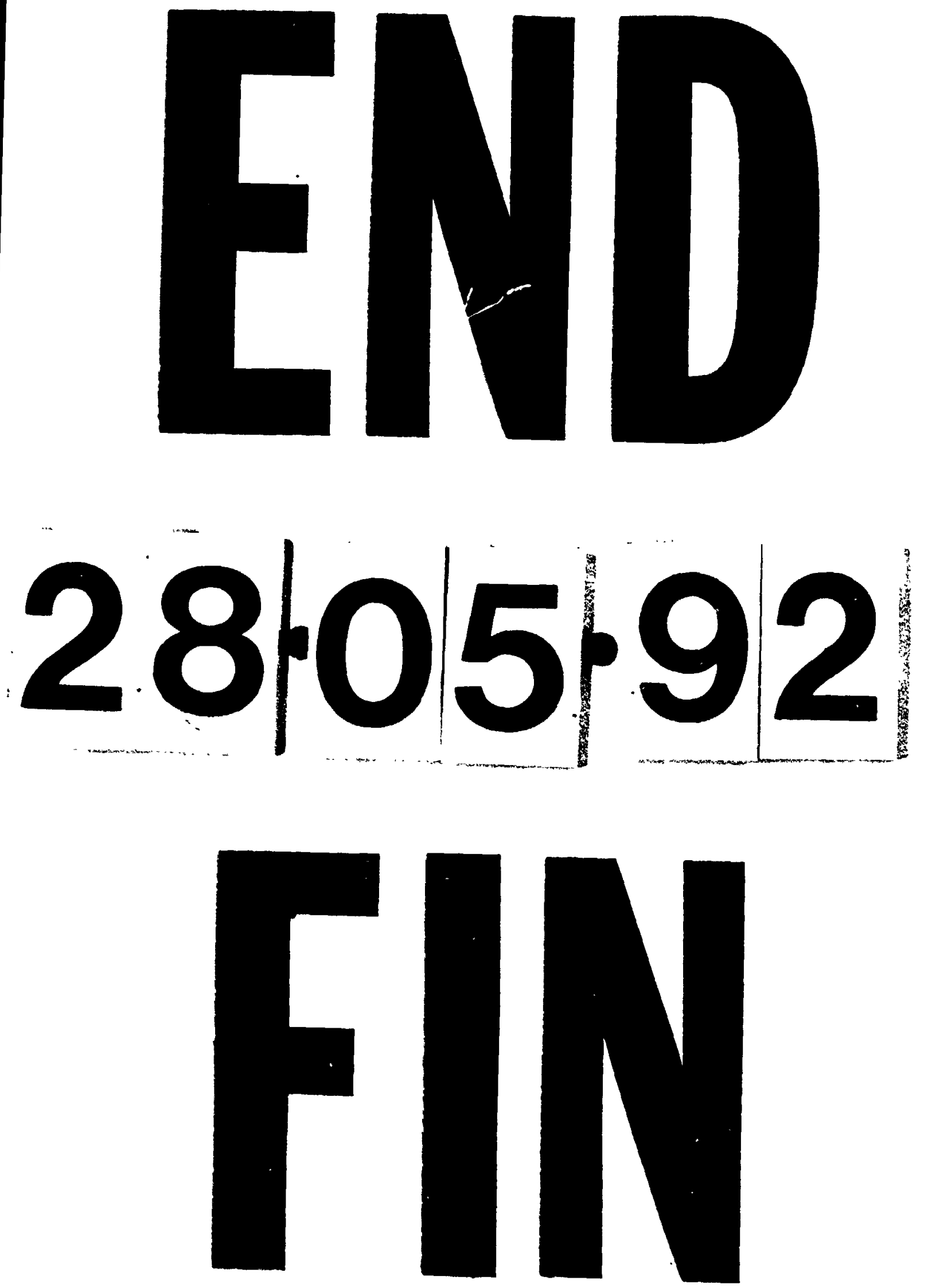